MTA Szegedi Biológiai Kutatóközpont

SZTE TTIK Biotechnológiai Tanszék

\title{
A bakteriális kommunikáció vizsgálata ágens alapú modellel
}

Ph.D. értekezés

Kerényi Ádám

\author{
Témavezetők: \\ Prof. Pongor Sándor \\ Dr. Rákhely Gábor
}

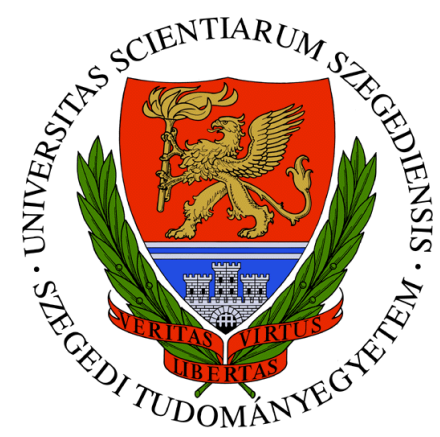

Szegedi Tudományegyetem

Biológia Doktori Iskola

Szeged

2014 


\section{Tartalomjegyzék}

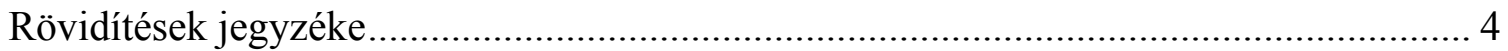

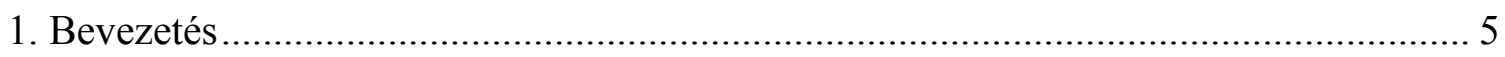

1.1. A molekuláris kommunikáció alapjai............................................................. 5

1.2. Mikrobiális közösségek és a quorum érzékelés biológiai háttere .............................. 7

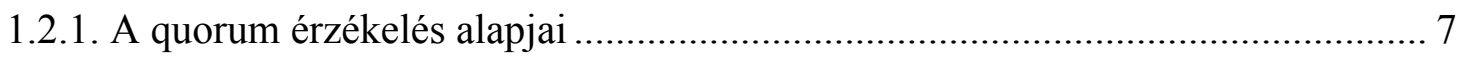

1.2.2. Néhány quorum érzékelés által szabályzott folyamat ...................................... 9

1.2.3. A quorum rendszerek endogén és exogén szabályozása ..................................... 9

1.3. A Pseudomonas aeruginosa quorum érzékelése................................................... 11

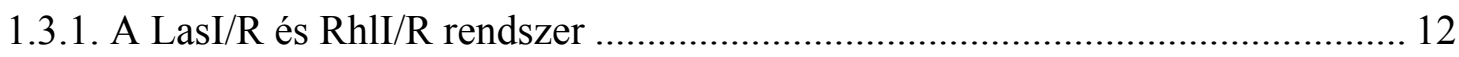

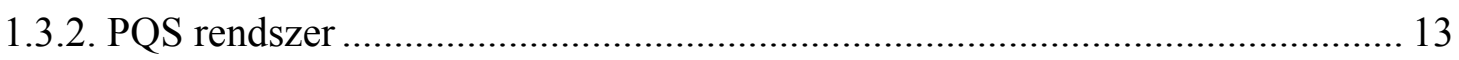

1.3.3. A Pseudomonas aeruginosa rajzó mozgása ................................................... 13

1.4. További mikrobiális quorum jelrendszerek............................................................ 15

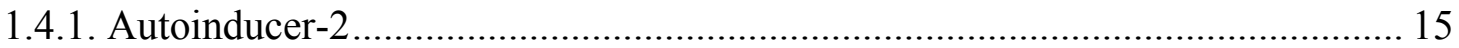

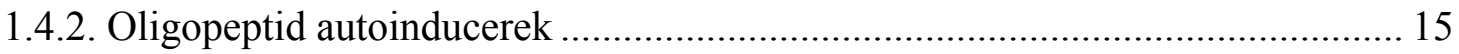

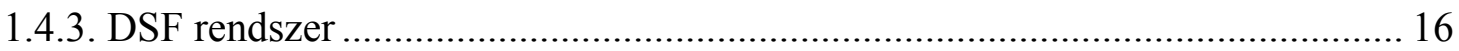

1.4.4. Gombák, valamint gomba-baktérium közösségek QS jelrendszerei................. 17

1.5. Polimikrobiális konzorciumok és stabilitásuk........................................................ 18

1.6. Baktériumpopulációk számítógépes modelljei.................................................... 20

1.6.1. Kawasaki modell (reakció-diffúziós modell) …................................................. 20

1.6.2. Reynolds modell (ágens alapú modell) ........................................................... 22

1.6.3. Ben-Jacob modell (hibrid modell)................................................................... 24

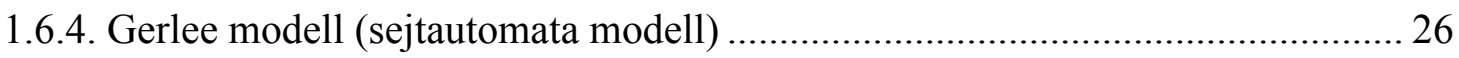

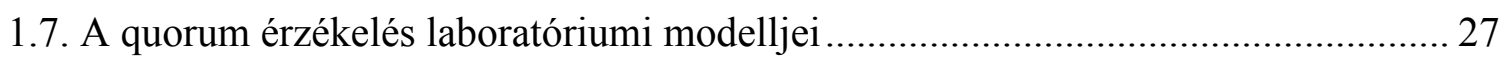

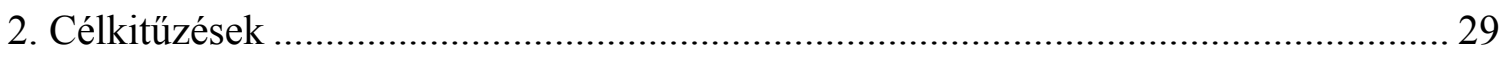

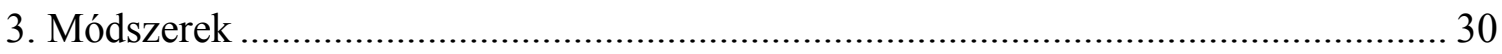

3.1 Baktériumtörzsek és a sejttenyésztés körülményei ................................................ 30

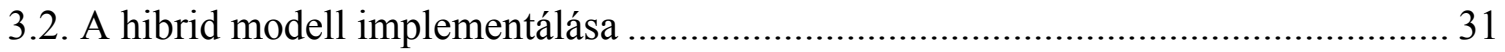

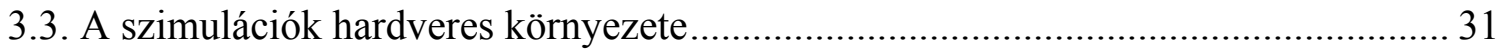

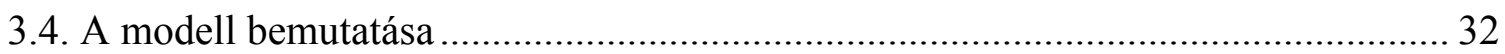

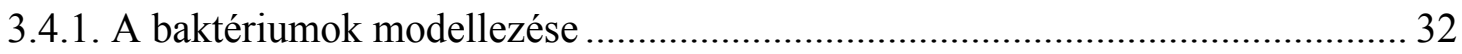

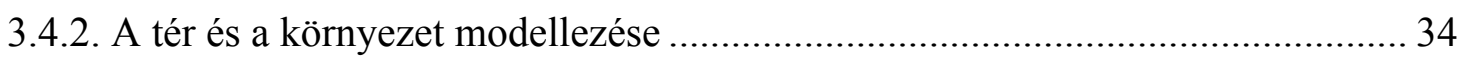

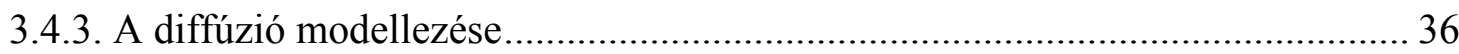


3.4.4. A program algoritmusa és müködése 37

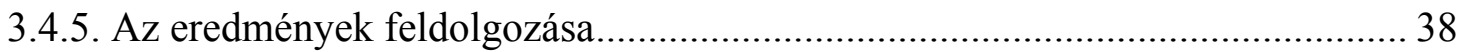

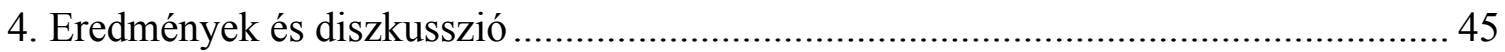

4.1. P. aeruginosa rajzásának in vitro és in silico vizsgálata ........................................ 45

4.1.1. A rajzás in vitro vizsgálata exogén jel hiányában és jelenlétében .................... 45

4.1.2. A rajzás in silico vizsgálata exogén jel hiányában és jelenlétében .................... 46

4.1.3. Sürüség függő aktiváció ágens populációkban ................................................. 47

4.1.4. Kémiai jelek követésének modellezése .......................................................... 48

4.2. A baktériumpopuláció lokális összeomlása csaló mutánsok megjelenése esetén..... 50

4.2.1. Lokális és globális kommunikáció mikrobiális közösségekben..........................50

4.2.2. A kísérleti rendszer bemutatása ...................................................................... 51

4.2.3. Vad típusú és különböző QS deléciós mutánsok együtt-rajzása ........................ 52

4.2.4. Kolóniadinamika in vitro kísérleteknél: rajzás és összeomlás .......................... 53

4.2.5. Populációdinamika in silico modellezése....................................................... 55

4.3. A kooperáció és kommunikáció in silico vizsgálata két fajból álló közösségekben. 59

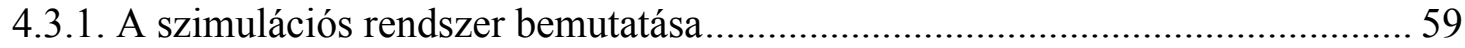

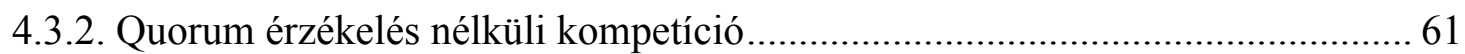

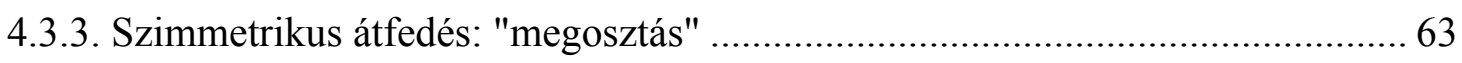

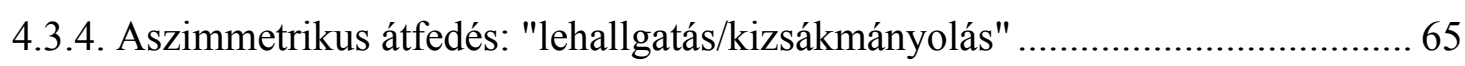

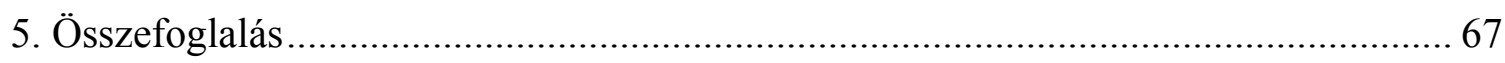

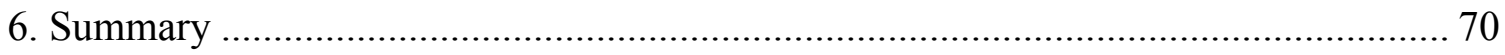

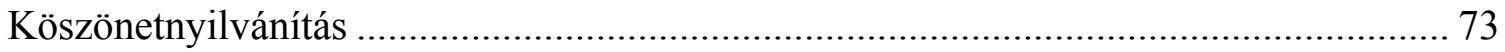

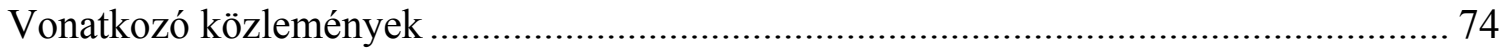

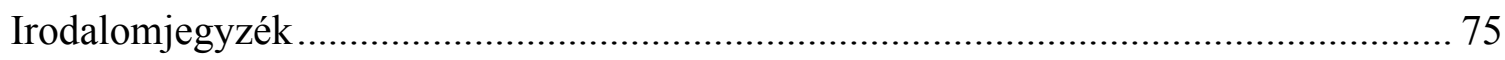

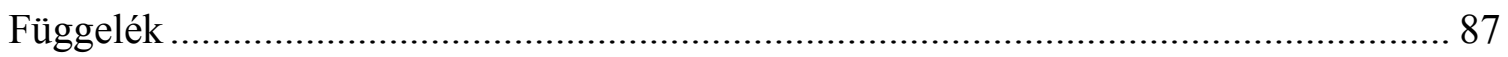




\section{Rövidítések jegyzéke}

\begin{tabular}{|c|c|}
\hline $1 \mathrm{D}$ & 1-dimenziós \\
\hline $2 \mathrm{D}$ & 2-dimenziós \\
\hline $3 \mathrm{D}$ & 3-dimenziós \\
\hline AHL & $\mathrm{N}$-acil-homoszerin lakton \\
\hline AI-2 & autoinducer-2 \\
\hline AIP & Autoinducer Peptide \\
\hline BDSF & Burkholderia diffúzibilis szignál faktor \\
\hline C12-AHL & N-(3-oxo-dodekanoil)-L-homoszerin lakton \\
\hline $\mathrm{C} 4$ & N-butanoil-L-homoszerin lakton \\
\hline C4-AHL & N-(3-oxo-butanoil)-L-homoszerin lakton \\
\hline $\mathrm{C} 6$ & N-hexanoil-L-homoszerin lakton \\
\hline C6-AHL & N-(3-oxo-hexanoil)-L-homoszerin lakton \\
\hline C8-AHL & N-(3-oxo-oktanoil)-L-homoszerin lakton \\
\hline $\mathrm{CF}$ & cisztás fibrózis \\
\hline $\mathrm{CFU}$ & Colony-Forming Unit \\
\hline DBM & Dense Branching Morphology \\
\hline DLA & Diffusion Limited Aggregation Pattern \\
\hline DPD & 4,5-hidroxi-2,3-pentándion \\
\hline DSF & diffúzibilis szignál faktor \\
\hline ET & Erwinia toletana \\
\hline $\mathrm{F}$ & Factor \\
\hline GFP & Green Fluorescent Protein \\
\hline IES & indolecetsav \\
\hline LB & Lysogeny Broth \\
\hline PA & Pantoea agglomerans \\
\hline PSV & Pseudomonas savastanoi pv. savastanoi \\
\hline PQS & Pseudomonas Quinolon Signal \\
\hline QS & Quorum Sensing \\
\hline rDR & Relative Division Rate \\
\hline S & Signal \\
\hline SB & Signal Blind \\
\hline $\mathrm{SN}$ & Signal Negative \\
\hline Sp1 & Species 1 \\
\hline $\mathrm{Sp} 2$ & Species 2 \\
\hline WT & Wild Type \\
\hline
\end{tabular}




\section{Bevezetés}

\subsection{A molekuláris kommunikáció alapjai}

A mikrobák változatos méretü és összetételü konzorciumokban élnek, melyek tagjai közösen használják fel a környezetükben található erőforrásokat. Ezek az ún. polimikrobiális közösségek a Földön mindenhol megtalálhatók: a talajban, az óceánok fenekén és egészen extrém környezetekben is, mint pl. hőforrásokban, vagy akár nukleáris hulladékban, de magasabb rendü élőlényekkel is élhetnek szimbiózisban [1]. A mikroorganizmusok közösségei fontos helyet foglalnak el a Föld ökoszisztémájában, hisz jelentős mértékben járulnak hozzá a biomasszához, illetve a szervetlen- és szerves anyag forgalomban is komoly szerepet töltenek be. A mikrobiális konzorciumok esetenkén több száz vagy ezer fajból állnak, melyek különböző szekretált anyagokat osztanak meg egymás között. Jelen információink alapján egyelőre nincs általánosan kielégítő magyarázat a közösségek stabilitására, vagyis arra, hogyan képesek tartósan fennmaradni és ellenállni a környezeti változásoknak, vagy a nem kooperáló, ún. csaló mutánsok elterjedésének. Ezek az elméleti kérdések gyakorlati szempontból is fontosak, mivel az emberi szervezet bélflórája, a rizoszféra nitrogén fixáló baktériumfajai, a fogszuvasodásban megtelepedő baktérium-gomba konzorciumok, valamint a víz alatti fémfelszíneket károsító biofilmek is mikrobiális közösségeket alkotnak. Így akár egészségügyi, akár ipari szempontból fontos feladat a stabilizáló mechanizmusok feltárása.

Kommunikációnak nevezzük az információ csere folyamatát, mely közös jelrendszerre épül. Biológiai szempontból a kommunikáció során egy egyed kibocsát egy jelzést, aminek hatására megváltozik egy másik egyed viselkedése. Számos prokarióta alkalmaz intercelluláris jelrendszert, melyet a különböző fajok például új élőhelyek kolonizálásakor, gazdaszervezetek megfertőzésekor használnak fel. A sejt-sejt kommunikáció révén a mikrobák oly módon változtatják meg viselkedésüket, ez által a környezetüket, amelyre a sejtek önállóan sokszor nem is lennének képesek. Jelérzékelésük révén például a bakteriális közösségek követhetnek olyan exogén jelekből álló nyomokat, melyeket a velük szimbiózisban élő növény állít elő [2-3]. Hasonló módon, jeleket érzékelve elkerülhetnek, vagy megtámadhatnak más baktérium kolóniákat. A jelenség hátteréről viszonylag sokat tudunk: egyrészről ismerjük a molekuláris genetikai szabályzó mechanizmusokat, másfelől sok információval rendelkezünk a fenotípusokról, és a populációk dinamikájáról. Viszont számos megválaszolatlan kérdés van még a jelenségek teljes megismerése előtt.

A bakteriális kommunikáció egyik nélkülözhetetlen összetevője az érzékelés, mely régóta ismert jelenség a mikrobiológiában. Egyik ismert példája a kemotaxis, mely során a 
sejtek képesek a számukra szükséges kémiai anyagok (attraktánsok) felé úszni, illetve a sejtek számára toxikus anyagoktól (repellensek) eltávolodni [4]. Szempontunkból a kemotaxis tehát a kémiai környezet molekuláris szenzorok általi érzékelését és az arra válaszként jelentkező sejtmozgást jelenti.

A bakteriális kommunikáció egy újabb szintjén a sejtek nem csak a környezetükben található, hanem a maguk által megtermelt jeleket is képesek érzékelni (autokrin érzékelés), melyek hatására jelentősen megváltozik a sejtek génexpressziós mintázata. A folyamat jelmolekulák koncentrációjának percepcióján alapul, a jelenséget pedig quorum érzékelésnek ('quorum sensing' - QS) hívjuk [5]. A QS , mely dolgozatom egyik központi eleme, az 1.2.1. fejezetben kerül részletes ismertetésre.

Abban az esetben, ha a sejtek kölcsönös érzékelése mellett a környezetük egyéb tényezőivel is kölcsönhatnak, akkor egy még magasabb szintü kommunikációról beszélhetünk [6]. Például a gerincesek bélrendszerében bonyolult összetételű baktériumkolóniákat találhatunk (bélflóra, vagy mikrobiom) [7]. Ezekben a szimbiózisokban a gazdaszervezet a baktériumok fennmaradásához optimális környezetet biztosít, cserébe a baktériumok hasznos anyagokat termelnek, ill. segítenek a gazdaszervezet számára emészthetetlen anyagok lebontásában. A bakteriális kommunikáció típusait az 1. ábrán foglaltam össze:

A

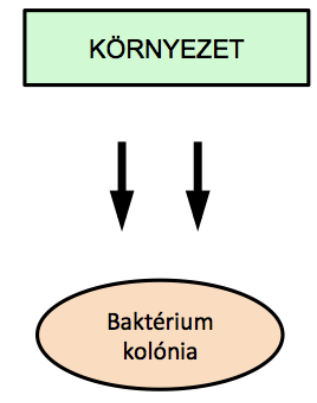

B
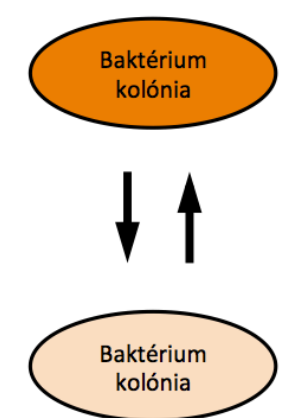

C

GAZDASZERVEZET

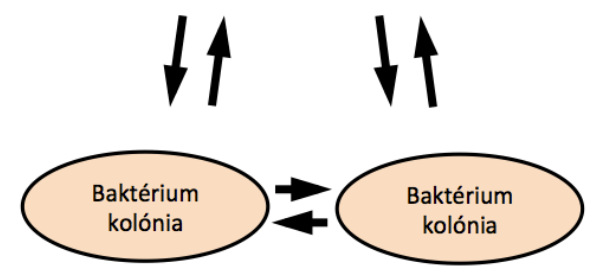

1. ábra: A bakteriális kommunikáció típusai: A) Környezeti jelek érzékelése (pl. kemotaxis). B) Saját jelmolekulák érzékelése (pl. quorum érzékelés). C) Környezeti jelek (pl. további fajok, gazdaszervezet) és saját jelmolekulák érzékelése (pl. mikrobiom). A fekete nyilak az információ áramlását jelölik.

Dolgozatomban stabilitás alatt a vizsgált rendszer, vagyis a baktériumközösség tartós fennmaradását és annak látszólagos egyensúlyát értem. Munkám középpontjában különböző baktériumtörzsek rajzó mozgásán alapuló jelenségek, valamint több fajból álló konzorciumok stabilitásának vizsgálata áll. Mivel ezeknek a jelenségeknek az alapját feltehetően a quorum 
érzékelés képezi, ezért a következőkben részletesen bemutatom a jelenség molekuláris hátterét.

\subsection{Mikrobiális közösségek és a quorum érzékelés biológiai háttere}

\subsubsection{A quorum érzékelés alapjai}

Az elmúlt 30 év egyik legjelentősebb mikrobiológiai felfedezése a baktériumsejtek közötti kémiai kommunikáció feltárása volt, mely alapjaiban változtatta meg a prokariotákról alkotott elképzelésünket [8]. Korábban az intercelluláris kommunikációt inkább eukarióta jellegzetességnek tartották, mára azonban nyilvánvalóvá vált, hogy a mikrobiális közösségek kommunikációja és komplex müködése mögött is bonyolult kémiai jelrendszerek állnak. A legtöbb baktériumfaj például képes érzékelni a populáció sejtsűrüségét kis molekulatömegü jelmolekulák (autoinducerek) termelése és érzékelése által. Ezt a jelenséget quorum érzékelésnek hívjuk, amely populáció sürüséggel korreláló inger-válasz rendszert jelent [5]. A „quorum” egy latin eredetű szó, melyet a római jogban a határozatképességhez szükséges legkisebb létszámot jelöli, mikrobiológiai szemszögből a populáció sürüségének érzékelésére utal. A folyamat során, ha a jelanyag, vagyis az autoinducer molekula koncentrációja elér egy kritikus szintet, akkor specifikus gének be- és kikapcsolása révén a teljes populáció génexpressziós mintázata megváltozik. A populáció egyedeinek szinkronizált válasza lehetővé teszi, hogy a kolónia alkalmazkodjon a megváltozott környezethez. Továbbá, a populáció denzitásának érzékelése jelentős mérföldkő lehetett a többsejtü szervezetek kialakulásánál [5, 9-10].

A QS folyamata során expresszálódó gének hatására a sejtek különböző extracelluláris anyagokat termelhetnek, amelyek lehetnek pl. virulencia faktorok, antibiotikumok, emésztőenzimek, fémkötő- (sziderofór) és felületaktív anyagok. Ezen felül komplex fenotipikus változások is létrejöhetnek a populáció és az egyed szintjén egyaránt, mint például a rajzó mozgás ('swarming motility') vagy a kompetens állapot kialakulása [11]. Néhány konkrét példát a következő fejezetben fogok ismertetni.

A baktériumok quorum érzékelésének elsőként leírt példája a kurtafarkú tintahallal (Euprymna scolopes) szimbiózisban élő Vibrio fischeri biolumineszcenciája volt [8, 12]. A baktériumban leírt QS kör szoros analógiát mutat a többi Gram-negatív fajban leírt quorum érzékelési struktúrával. A rendszer két fő komponensből áll: egy szintáz fehérjéből (LuxI), mely az autoinducer termeléséért felelős, továbbá egy receptor proteinből (LuxR), mely a jelmolekulával kötődve transzkripciós faktorként szabályozza további gének expresszióját 
(2. ábra). Az autoinducer a $V$. fischeri esetében, valamint a legtöbb Gram-negatív fajnál az Nacil-homoszerin laktonok (AHL) csoportjába tartozik. Ezek a molekulák tartalmaznak egy konzervált homoszerin lakton gyürüt, melyhez egy változó hosszúságú acil oldallánc kapcsolódik, melynek hossza 3 és 18 szénatom közé esik. Az acil oldalláncok a változó lánchosszúság mellett különböző telítettségüek lehetnek, valamint a C3 pozícióban lévő oxoill. hidroxil csoportok alapján a molekulák nagy változatosságot mutatnak, emellett azonban specifikusak az adott fajra nézve. Továbbá, a homoszerin laktongyürü felelös a molekula hidrofil jellegéért, míg a lánchosszúság, a telítettség és a szubsztitúciós profiltól függ a hidrofobicitás. Az AHL molekulák szabadon diffundálnak a sejtmembránon keresztül, de hosszabb oldalláncú molekulák esetében előfordulhatnak a transzportot elősegítő efflux pumpák is. A $V$. fischeri LuxI fehérjéje szintetizálja az N-(3-oxo-hexanoil)-L-homoszerin lakton (C6-AHL) jelmolekulát, mely egy kritikus koncentrációt elérve komplexet képez a LuxR proteinnel. Az így kialakuló transzkripciós faktor aktiválja a luxICDABE operon génjeinek átírását, mely eredményeként expresszálódik a biolumineszcenciáért felelős luciferáz enzim (2. ábra).

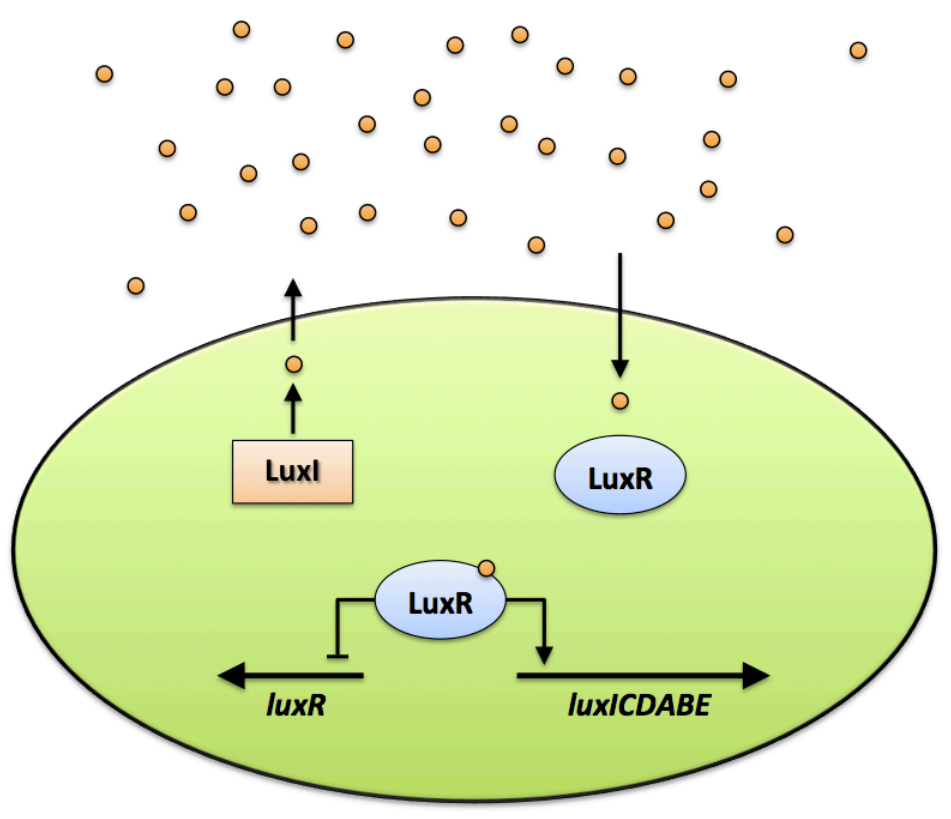

2. ábra: A Vibrio fischeri QS rendszere: A LuxI szintázfehérje által termelt C6-AHL jelmolekulák a kritikus koncentrációt elérve kötőnek a LuxR intracelluláris receptorfehérjéhez. Az így kialakuló C6-AHL-LuxR komplex transzkripciós faktorként müködésbe hozza a luxICDABE operont [13]. A luxI gén transzkripciója által fokozódik az autoinducer termelése (pozitív feedback). Továbbá, a LuxR-autoinducer komplex a luxR promóterhez is kötődik, gátolva a luxR transzkripcióját (negatív feedback). 


\subsubsection{Néhány quorum érzékelés által szabályzott folyamat}

A $V$. fischeri biolumineszcenciája mellett mára több faj QS rendszerét azonosították. A Gram-pozitív és Gram-negatív baktériumok számos biológiai folyamata denzitás függő, melyek közül a legfontosabbak: a szimbiotikus, a virulens és a kompetens állapot létrehozása, a konjugáció, a sporuláció és a mozgás szabályozása, valamint az antibiotikum termelés, az exoenzim termelés és a biofilm képzés kontrollálása. A 1. táblázatban néhány jellemző példát foglaltam össze a quorum érzékelés által koordinált bakteriális fenotípuskról [13].

1. táblázat: Bacillus és Pseudomonas baktériumfajok QS mechanizmus által szabályozott fenotípusai.

\begin{tabular}{|c|c|c|}
\hline Baktériumfaj & Quorum rendszer & Fenotípus \\
\hline B. glumae BGRl & tofIR & $\begin{array}{l}\text { poláris flagellum képzés, úszó mozgás, rajzó } \\
\text { mozgás [14] }\end{array}$ \\
\hline B. thailandensis & btaIR1/btaIR3 & rajzó, ill. „twitching” mozgás [15] \\
\hline B. cenocepacia J 2315 & cepIR, cciIR & rajzó mozgás, biofilm létrehozás [16] \\
\hline B. vietnamiensis $G 4$ & cepIR,bviIR & $\begin{array}{l}\text { rajzó mozgás, biofilm létrehozás, } \\
\text { kitináz termelés [17] }\end{array}$ \\
\hline B. pseudomallei 1710 & bpmlIR & MprA metalloproteáz termelés [18] \\
\hline B. glumae BGRI & tofIR & toxoflavin termelés [14] \\
\hline B. thailandensis & btaIR1/btaIR3 & $\begin{array}{l}\text { lipáz és béta-hemolizin termelés, } \\
\text { rajzó mozgás [15] }\end{array}$ \\
\hline B. subtilis & $\operatorname{com} Q X P A$ & 'surfactin' termelés [19] \\
\hline B. pseudomallei 1710 & bpmIR & $\begin{array}{l}\text { MprA metalloproteáz termelés, virulens állapot } \\
\text { (melioidózis) [18] }\end{array}$ \\
\hline B. pseudomallei K96243 & bpsIR1, bpsIR2, bpsIR3 & virulens állapot (melioidózis) [15, 20-21] \\
\hline P. aerugenosa & lasIR, rhlIR & virulens állapot, rajzó mozgás [22] \\
\hline B. subtilis & $\operatorname{com} Q X P A$ & kompetens állapot [11] \\
\hline B. ambifaria & bafIR & antifungális állapot [23] \\
\hline B. thailandensis & btaIR2 & baktobolin termelés [24-25] \\
\hline B. sp.383 (B. lata 383) & cepIR & pirrolnitrin termelés [26] \\
\hline B. сепосерасіа J2315 & cepIR & ornibaktin termelés [27] \\
\hline
\end{tabular}

\subsubsection{A quorum rendszerek endogén és exogén szabályozása}

A $V$. fischeri QS rendszerében megfigyelték, hogy a luxI és luxR gének egy pozitív indukciós körben vannak, vagyis a rendszer aktiválása esetén gyorsan megnövekszik a termelődő jelmolekula koncentrációja (autoindukció). Ez a pozitív feedback mechanizmus biztosítja, hogy a sejtek egyértelmü és határozott válaszreakciót fejtsenek ki a kritikus koncentrációt elérve. Az AHL alapú QS rendszerekben magas jelkoncentráció esetén az autoindukció mellett egy negatív visszacsatolás biztosítja, hogy a sejt korlátozott mértékben 
termeljen jelmolekulákat [28]. Általánosságban a receptor-autoinducer komplex gátolja a szintáz, vagy a receptor előállításáért felelős gének müködését, felfüggesztve a jelmolekulák, ill. az azok érzékeléséhez szükséges receptorok további termelését. Az autoindukciós- és a stabilizációs kör sémája a 3. ábrán látható.

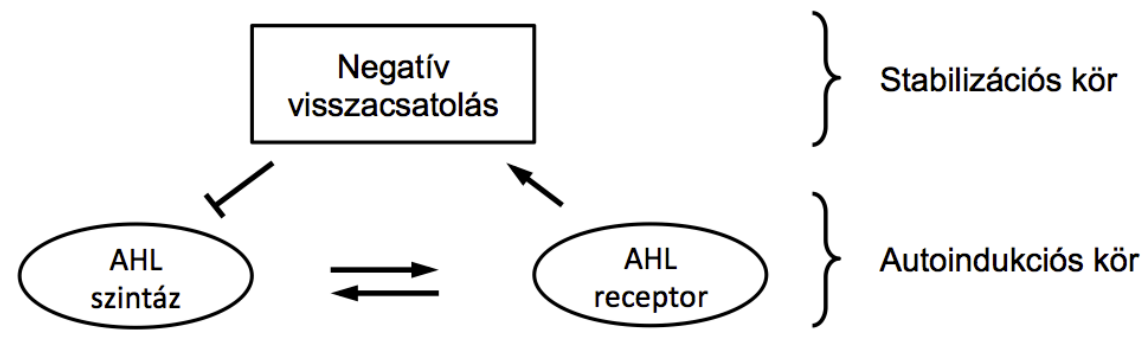

3. ábra: Az AHL alapú QS rendszerek regulációs sémája. A nyilak génaktivációt jelölnek, míg a zárt végú vonal gátlást jelöl [28].

A negatív visszacsatolás egy viszonylag egyszerü mechanizmus, mellyel limitálni lehet a jeltermelést. Az egyik negatív regulátor fehérje az RsaL, mely homo-dimerként kötődik az rsaL-luxI promóterhez [29]. A fehérjét nem expresszáló mutánsok intenzívebben mozognak szilárd felületeken, valamint nagyobb mértékben termelnek virulencia faktorokat, mint a vad típusú sejtek. Egy másik fehérje, az RsaM is hasonló funkcióval rendelkezik, mint az RsaL, mely hiányában az AHL molekulák szintézise megnő [30-31].

A sejtek endogén QS szabályozása mellett további mechanizmusok is léteznek, melyekkel lehetőség nyílik QS rendszerek blokkolására. Ezek közül az egyik mechanizmus a jelmolekulák kémiai lebontása, melyet 'quorum quenching'-nek hívunk [32-33]. Fajok közötti kompetíció esetében a közös niche-en osztozó baktériumok esetében jelentős előnyre tehet szert az egyik faj, ha képes blokkolni a másik faj jelrendszerét annak jelmolekuláinak emésztésével. Két enzimrendszert is azonosítottak, melyek AHL-lebontásra képesek: az $A H L$ laktonázok a jelmolekula lakton gyürüjén található észter kötés hidrolizálják, míg az $A H L$ acilázok a molekula amid kötését acilálják [33-35]. Ezeket az enzimeket többek között Bacillus sp. és Variovorax paradoxus fajokból izolálták, melyek egyébként nem termelnek AHL jelmolekulákat [34, 36]. Később azonosítottak hasonló funkciójú enzimeket AHL termelő fajokból is (Agrobacterium, Pseudomonas). Ennek a jelenségnek is van egy lehetséges evolúciós magyarázata, ugyanis az AHL koncentrációjának csökkenése a stacionárius fázisban figyelhető meg, így a sejtek elkerülhetik a sokszor energiaigényes QS által indukált folyamatok bekapcsolását. Feltételezések szerint ezek az endogén enzimek 
eredendően a sejt metabolikus rendszerének a részei, vagyis nem az AHL inaktiváció az elsődleges funkciójuk.

Az AHL laktongyürüjének hidrolíziséért felelős enzimekkel magasabb rendű élőlények esetében is találkozhatunk: az emlős sejtvonalak által termelt paraoxonáz enzim [37-38] inaktiválja az AHL molekulákat, mely által a szervez képes blokkolni a kórokozó QS rendszerének szabályozása alatt álló virulencia faktorok termelését [39-40]. Néhány növénynél is megfigyelték a QS jelrendszer inaktivációjának képességét, de a pontos mechanizmus egyelöre ismeretlen [41].

A munkám során vizsgált organizmus a Pseudomonas aeruginosa volt, így a továbbiakban annak QS rendszerét ismertetem részletesebben.

\subsection{A Pseudomonas aeruginosa quorum érzékelése}

A Pseudomonas aeruginosa egy Gram-negatív, opportunista patogén baktériumfaj, mely az aerob Gamma-proteobaktériumok osztályán belül a Pesudomonaceae családba tartozik. A baktérium számos élőhelyen, például vízben és talajban is megtalálható, de a baktériumfaj része az emberi bőr természetes flórájának is. Egyetlen poláris flagellummal, valamint számos IV típusú pílussal rendelkezik [42]. Szöveti- és égési sérülések, illetve legyengült immunrendszer esetén gyulladást és szepszist képes előidézni, továbbá jellemzően húgyúti, és felső légúti fertőzéseket okoz. A faj megfelelő környezetben kolonizációra is képes, melyre a legjellemzőbb példa a cisztás fibrózisos (CF) betegek tüdejében kialakuló biofilm [43-44]. A kialakuló baktérium réteg miatt a beteg nem képes oxigént felvenni a tüdő felületén keresztül, ezért a CF betegek számára a $P$. aeruginosa fertőzés többnyire halálos kimenetelü. Mivel a kolónia képzés szempontjából a nedves felületek (pl. katéterek) kedveznek, kórházakban komoly problémát okoznak a Pseudomonas fertőzések.

A P. aeruginosa a quorum érzékelés tanulmányozásának közkedvelt modellorganizmusa, így a rendszer molekuláris háttere nagy részletességgel fel lett tárva, továbbá a faj teljes genomjának szekvenciája ismert, mely az online adatbázisokban folyamatosan frissül (www.pseudomonas.com). Továbbá, különböző, jól feltérképezett genommal rendelkező, különböző kísérleti rendszerekben jól alkalmazható mutánsok állnak a kutatócsoportok rendelkezésére.

A baktériumfajban két QS kör található: a lasI/R [9] és az rhlI/R [45] rendszerek, melyek a luxI/R rendszer homológjai. 


\subsubsection{A LasI/R és $R h I I / R$ rendszer}

A P. aeruginosa két QS rendszere hierarchikus felépítésủ, melynek legfelső szintjén a LasI/R rendszer áll (4. ábra). Az elsődleges rendszerben, a luxI homológ lasI gén által termelt szintáz (LasI) felelős az N-(3-oxo-dodekanoil)-L-homoszerin lakton (C12-AHL) termeléséért, mely a receptorhoz (LasR) kötődve beindítja bizonyos célgének expresszióját. A C12-AHLLasR komplex indukálja a las $I$-t is, mely által létrejön a QS rendszerekre jellemzö autoindukciós kör. Továbbá, az C12-AHL-LasR komplex aktiválja a RhlI/R rendszert is az rhlI expressziója által, valamint indukálja a következő fejezetben bemutatásra kerülő PQS rendszert is. Az RhlI/R rendszerben az RhlI szintáz egy négy szénatomos acil oldalláncú jelmolekulát termel, az N-(3-oxo-butanoil)-L-homoszerin lakton (C4-AHL), mely az RhIR receptorjához kötődve aktiválja a célgéneket. A két rendszer müködése tehát szorosan összefügg és a következő virulencia faktorok termelését szabályozzák: elasztáz, lipáz, proteázok, exotoxin A, rhamnolipidek, hidrogén-cianid, pyocyanin, lektinek, valamint szuperoxid diszmutáz. Ezen felül az említett QS rendszerek felelősek a biofilm képződésért, a rajzó mozgásért, valamint a virulencia kialakulásáért [45].

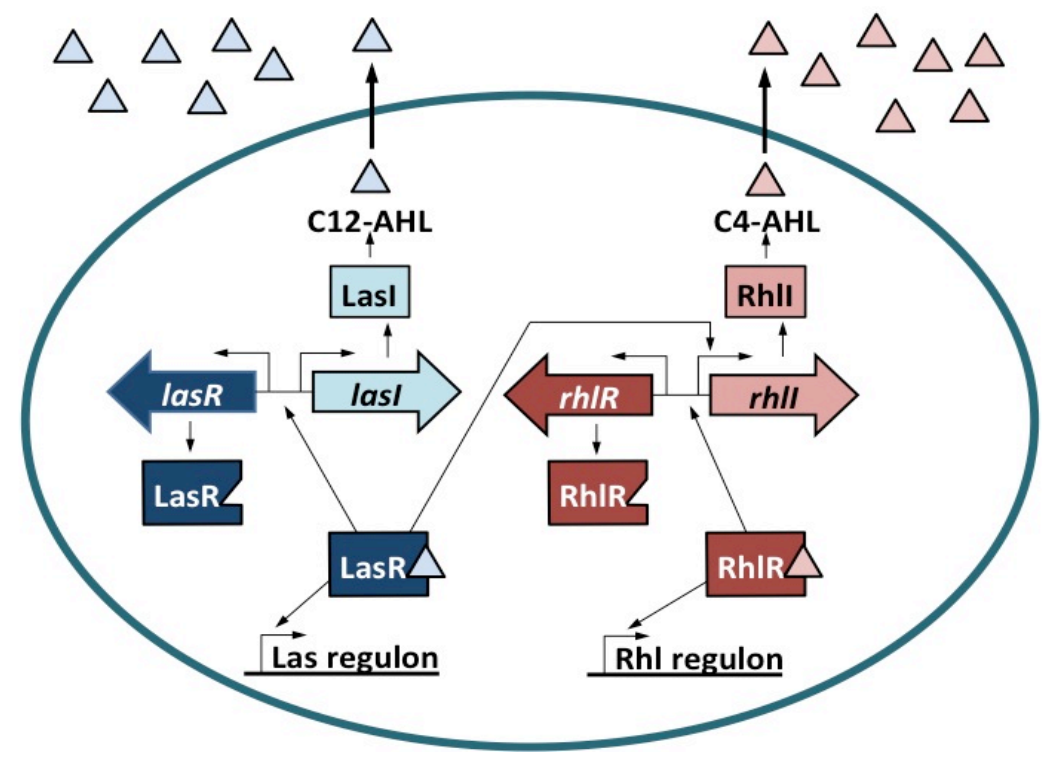

4. ábra: A P. aeruginosa többszintü QS rendszere. A LasI által termelt C12-AHL autoinducer (kék háromszög) a LasR intracelluláris receptorhoz kötődve indukálja a célgének expresszióját. A LasR-C12-AHL komplex felelős az RhlI expressziójáért is, mely a C4-AHL (piros háromszög) autoinducer termeléséért felelös. Az RhlR-C4AHL komplex indítja be az Rhl regulonban található gének expresszióját. 


\subsubsection{PQS rendszer}

A $P$. aeruginosa egy további jelmolekulát is termel, a 2-heptil-3-hidroxi-4-kinolont, melyet röviden 'Pseudomonas Quinolon Signal'-nak (PQS) hívunk. A molekula a Triptofán aminosav bioszintézisének köztiterméke [46-47] és a 4-quinolone-ok családjába tartozik, melyek föként antibiotikus hatásaikról ismertek. A jelmolekula termelődése a stacionárius fázis korai szakaszához [48], a las és az $r h l$ rendszer aktivációja utáni időszakhoz köthető. A PQS-t a pqsABCD operon fehérjéi szintetizálják antranilát prekurzorból [49-50]. A jelmolekula termelése közvetlenül a LasR fehérjétöl függ [46], míg a teljes pqs operon müködését a las rendszer szabályozza [51]. További érdekesség, hogy a PQS jelmolekula hatással van a las operon egyik tagjának, a lasB-nek az expressziójára is [46].

Feltételezések szerint a PQS fontos összekötő kapocs lehet a las és az rhl QS rendszerek között az rhlI transzkripció regulációja által, viszont valószínűleg nincs a populáció sürüségének érzékelésére vonatkozó közvetlen funkciója [52].

A bemutatott AHL és PQS rendszerek mellett a $P$. aeruginosa termel egy ciklikus dipeptidet, a diketopiperazint, mely jelmolekulaként funkcionálhat a fenti QS körökben [53]. A dipeptid ugyanis verseng az AHL molekulákkal a LuxR regulátorhoz kötődésért. Ez által a diketopiperazin gátolhatja a a lasI és rhlI rendszerek negatív visszacsatolását, így közvetlenül befolyásolja az AHL jelmolekulák termelődését.

\subsubsection{A Pseudomonas aeruginosa rajzó mozgása}

A QS rendszerek mechnizmusa egyed szinten valósul meg, viszont a következmények populáció szinten érvényesülnek. Erre szemléletes példa a korábban említett biolumineszcencia jelensége a Vibrio fischeri esetében (áttekintve Ruby által [54]). Emellett egy másik ismert jelenség a $P$. aeruginosa rajzó mozgása ('swarming motility', áttekintve Daniels által [55]), mely a baktériumkolónia gyors helyváltoztató mozgását jelenti. Mivel a rajzó mozgás QS rendszer szabályzása alatt áll, feltételezhető, hogy a túl nagy sejtsűrüség, valamint a kedvezőtlen környezet miatt a kolónia a területen történő optimális eloszlásával próbálja növelni a túlélési esélyeit [56]. Más elméletek szerint a baktériumok nem más sejteket, hanem a környezetük fizikai paramétereit érzékelik [57], vagyis ha a jelmolekula felhalmozódik, akkor az tükrözheti a sejtek szilárdabb felszínen történő elhelyezkedését. Ennek hatására a sejtek olyan mozgásformára válthatnak, mellyel gyorsabban mozoghatnak megfelelő szilárdságú felszínen, a folyadékban történő úszáshoz képest. 
Evolúciós szempontból a koordinált viselkedési mintázatok - pl. a felszín kolonizációja az említett rajzó mozgás által, vagy a biofilm képzés fontos mérföldkövek lehetettek a többsejtűség kialakulásában [58]. A rajzó mozgás jelenséget részletesen Jorgen Henrichsen [59] írta le, aki hat különböző transzlokációs formát különböztetett meg, melyek közül a legismertebb a flagella által hajtott rajzás. Ezt a jelenséget a Pseudomonas fajok mellett leírták Proteus, Vibrio, Bacillus, Clostridium, Escherichia, Salmonella, Azospirillum, Aeromonas, Yersinia, Serratia, Burkholderia, valamint Sinorhizobium fajokban is [60-65]. Az úszással ellentétben, ahol a sejtek az agar táptalaj (0.2-0.4\% agar) csatornáin keresztül úsznak, a rajzó mozgás során a sejtek félig szilárd felszínen (0.4-1.2\% agar) végeznek koordinált helyváltoztatást.

A $P$. aerugniosa esetében a sejteket flagellák hajtják előre. A mozgás további feltétele egy extracelluláris felületaktív anyag, a rhamnolipid termelése. A molekula egy glükolipid, mely glikozil fejből és alkanoil sav farokból áll. A kolónia által termelt rhamnolipid tehát egy nedves, nyálkás környezetet hoz létre, ill. a felületi feszültség csökkentése által lehetőséget teremt a baktériumok szilárd felületeken történő szétterjedésének [66]. A rajzó sejtek esetében több fajnál megfigyelték a sejtek morfológiai változásait: a megnövekedett viszkozitás és az intracelluláris jelek hatására a sejtek megnyúlnak, a nukleoid megsokszorozódik. Ezek mellett, a hatékonyabb mozgás céljából flagellumok száma megsokszorozódik, vagyis a sejtek hiperflagelláltak lesznek.

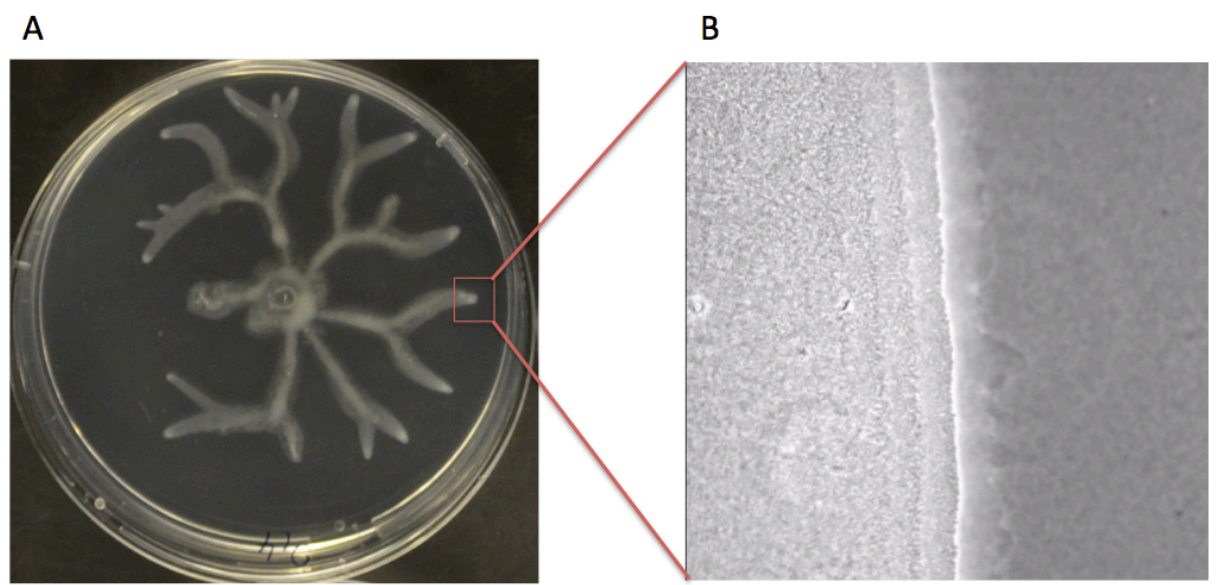

5. ábra: A) A táptalaj közepére oltott $P$. aeruginosa folyadékkultúrából 18-24 óra inkubáció $\left(37 C^{\circ}\right)$ során $^{2}$ alakulnak ki a képen látható fraktálszerü telepek. B) Egy dendrit végének fáziskontraszt mikroszkópos felvételén látható a kolónia határa (100x-os nagyítás). A sejtek a határvonal mentén egyetlen sejtrétegben helyezkednek el, mögötte 2, majd 3, végül sok sejtből álló zónák láthatók. 
Laboratóriumi kísérletek során speciális összetételü agar médium (lásd Függelék, 1. táblázat) közepére cseppentik a $P$. aeruginosa folyadékkultúrát, melyen néhány óra után megindul a rajzó mozgás és jellegzetes dendritszerü nyúlványok képződnek (5. ábra).

A rajzó mozgásnak a gyors helyváltoztatás mellett további gyakorlati jelentősége is van. Például, fontos lépése a biofilm képződésnek [67-68], valamint a növény-baktérium interakciók esetében kiemelt szerepe van a gyökér kolonizációban [2-3].

Mivel a jelenség laboratóriumi körülmények között jól vizsgálható, munkánk alapját a P. aeruginosa rajzó mozgásának megfigyelése képezte.

\subsection{További mikrobiális quorum jelrendszerek}

\subsubsection{Autoinducer-2}

Az AHL alapú QS rendszerek mellett párhuzamosan kifejlődött egy másik rendszer, mely jelmolekulája a bór atomot tartalmazó furanozil-bór-diészter, melyet röviden autoinducer-2-nek nevezünk (AI-2, 6. ábra). A rendszer megtalálható Gram-pozitív és Gramnegatív fajoknál is, és feltételezhetően fontos szerepe lehet a fajok közötti kommunikációban. A molekula prekurzora a DPD (4,5-hidroxi-2,3-pentándion) melyet a LuxS protein állít elő Sadenozin-metioninból, amely egyébként az AHL rendszer prekurzora is [69]. További érdekesség, hogy fajok között lehetnek specifikus eltérések a jelmolekula felépítésében. Például a Vibrio harveyi AI-2 molekulája tartalmaz egy bór atomot, addig a Salmonella jelmolekulája nem. Az AI-2 a LuxP proteinhez kapcsolódik, mellyel komplexet alkotva egy foszforilációs kaszkád indul el, a célgének aktivitását eredményezve [70].

\subsubsection{Oligopeptid autoinducerek}

Az AHL és AI-2 mellett további jelmolekula típusokkal is találkozhatunk a mikrobáknál. Gram-pozitív baktériumok quorum rendszerének jelmolekulái lehetnek oligopeptidek, melyek hosszúsága 5 és 34 aminosav közé esik (6. ábra). Ezek a többnyire poszttranszlációsan módosult peptidek tartalmazhatnak lakton és tiolakton gyürüket, lantioninokat, valamint izoprén csoportokat. Ezekre a peptidekre tehát a komplex biosztintézis jellemző [71]. A peptidek az AHL-ekkel szemben nem képesek passzívan átjutni a membránon, ezért aktív transzport proteinekre van szükség az extracelluláris térbe juttatásukhoz. A jelmolekulák sejtfelszíni receptorokhoz kötődnek, melyek foszforilációs kaszkádhoz kapcsolt szignáltranszdukciós utat indítanak el [72-73]. A receptor fehérjék rendkívül specifikusak az oligopeptidjükre, így elég egyetlen apró változtatás a peptiden és 
nem képes elindítani a szignalizációs folyamatot [74]. Az oligopeptid rendszerekre ismert példa a Bacillus subtilis ComX és CSF rendszere, a Streptococcus pneumoniae által termelt CSP peptid, valamint a Staphylococcus aureus négyféle AIP (Autoinducer Peptide) molekulája [75-77].

\subsubsection{DSF rendszer}

A diffúzibilis szignál faktort (DSF) elsőként Xanthomonas campestrisben azonosították, de további fajok is képesek elöállítani, mint például Xanthomonsa oryzae, Xylella fastidiosa és a Stenotrophomonas maltophilia. A DSF molekula egy telítetlen zsírsav (cisz-11-metil-2 dodecén sav), melyet az rpf klaszterben kódolt RpfF fehérje állít elő [78-79]. Ez a protein nem csak a jelmolekula termeléséért felelős, hanem receptorként is funkcionál.
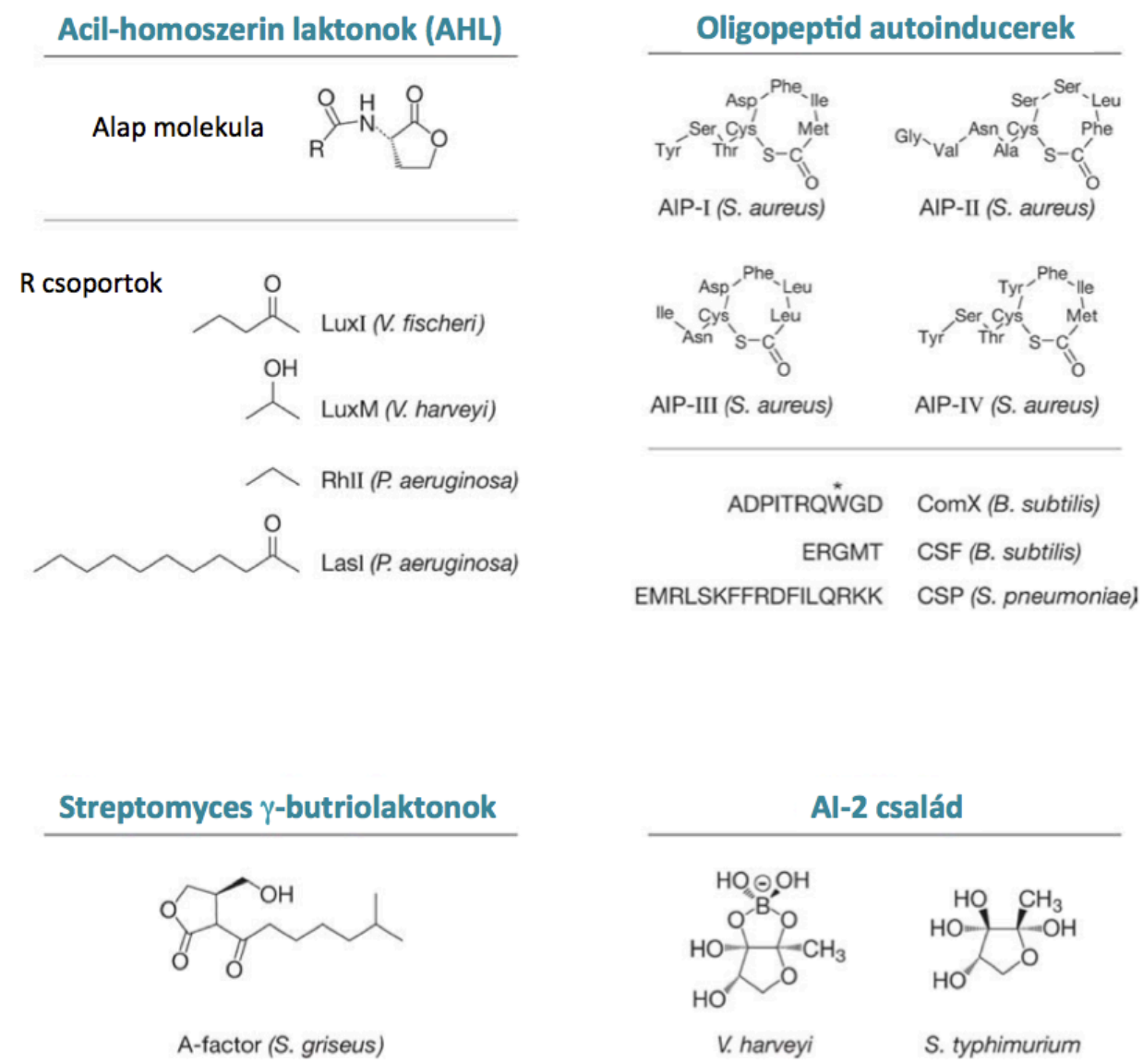

6. ábra: Különböző bakteriális QS rendszerek jelmolekulái [74].

Az rpf/DSF rendszer három fő komponensből áll: RpfF a jelmolekula termeléséért felelős, míg a kétkomponensü RpfC és RpfG rendszer a jelmolekula érzékeléséért, valamint a transzdukcióért felel [80]. Az rpf/DSF rendszer szabályzása alatt állhat például virulencia 
faktor rendszerek müködése, az aggregatív viselkedés, vagy a biofilm képződés. A DSF-hez hasonló rendszert azonosítottak egy Burkholderia fajban (BDSF), melynek szerepét a fajok közötti kommunikációban jelenleg is vizsgálják [81]. A BDSF molekula egyetlen metil csoportban tér el a DSF-től. A BDSF rendszer csak egyetlen komponensből áll, szemben a Xanthomonas DSF quorum rendszerével [82]. A 6. ábra a különböző bakteriális QS rendszerek szignálmolekuláit foglalja össze.

\subsubsection{Gombák, valamint gomba-baktérium közösségek QS jelrendszerei}

Az emberi testben a baktériumok sok esetben alkotnak közösséget egysejtü gombákkal, mely komoly egészségügyi problémákhoz vezethet [83-85]. A Candida albicans a szervezetünkben általánosan elforduló, alapvetően ártalmatlan gombafaj, viszont gyenge immunrendszerrel rendelkező egyénekben súlyos fertőzést okozhat. A C. albicans gyakran társul patogén baktériumokkal: orális fertőzéseknél Staphylococcus-szal, égési sérüléseknél Pseudomonas és Staphylococcus fajokkal, intraabdominális fertőzések esetében az Enterobacteriaceae tagjaival, valamint a légzési traktus fertőzéseinél Pseudomonas-szal. Ezen felül a C. albicans sokszor található meg az élesztő-szerü Malassezia társaságában katéterek felszínén. Valószínü, hogy ezek a közös fertőzések nem véletlenül jönnek rendszeresen létre, hanem specifikus molekulák koordinációja mellett alakul ki a jellemző összetételü sejtközösség.

A C. albicans többféle formában fordul elő: sarjadzó formában, valamint fonalas hifa, vagy más néven pszeudohifa formában, továbbá képes poliszacharid-mátrix alapú biofilm közösséget képezni. Az egyes állapotok közötti átmenetet kölönböző külső és belső jelek irányítják. Ilyen jelmolekula a farnezol (7. ábra), melyet a C. albicans sejtek termelnek és ami a sejtsürüségtől függően elnyomja a filamentációt. Ez volt az első QS rendszer, amit gombákban fedeztek fel [86]. A tirozol (7. ábra) a C. albicans egy másik QS jelmolekulája, mely hatására alacsony sejtsürüségü kultúrában lerövidül a lag fázis, anélkül, hogy az exponenciális fázis megváltozna [87]. A S. cerevisiae-ben is müködik QS rendszer: a feniletanol és a triptofol (7. ábra) a sejtsürüségtől függően indítja be a pszeudohifás növekedést. A legtöbb ismert gomba jelmolekula illékony, ezáltal egymástól távolabb elhelyezkedő szesszilis sejtek között is történhet információcsere.

A C. albicans és a $P$. aeruginosa gyakran hasonló környezetben fordulnak elö, és több módon hatnak kölcsönösen egymásra. A P. aeruginosa képes biofilmet képezni a C. ablicans telepeken, ill. elpusztítani a hifát fenazinok [88] és foszfolipáz C [89] termelésével. 


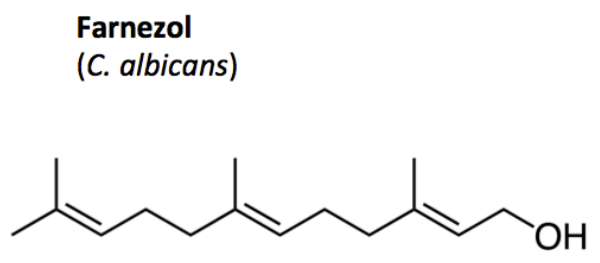<smiles>OCCc1c[nH]c2ccccc12</smiles>

Tirozol

(C. albicans

S. cerevisiae)<smiles>OCCc1ccc(O)cc1</smiles>

Feniletanol

(C. albicans

S. cerevisiae)

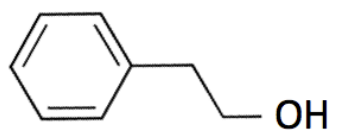

7. ábra: Néhány gombafaj QS rendszerének jelmolekulái [90].

Másrészről viszont a két faj képes kevert biofilmet létrehozni abban az esetben, ha $a$ C. albicans nem hifa, hanem sarjadzó állapotban van. A jelenség kialakulásához mindkét résztvevő által termelt jelmolekulákra szükség van. A $P$. aeruginosa által termelt AHL jelmolekulák ugyanis gátolják a $C$. albicans hifáinak kialakulását, így a gombasejtek a közös biofilmképzésre alkalmas sarjadzó állapotban maradnak. Ezen felül, a C. albicans a farnesol és további eddig azonosítatlan faktorok által hatással van a $P$. aerugionsa quorum rendszerére $[88,91]$.

\subsection{Polimikrobiális konzorciumok és stabilitásuk}

Csoportunk egyik korábbi munkájában leírtuk, hogy vad típusú $P$. aeruginosa jelmolekula termelésére képtelen, de a "közjavak" ('public goods') termelésére képes mutánssal stabil közösséget formálhat [92]. A kooperációra, vagyis a közjavak termelésére képtelen mutáns viszont gyors elszaporodása után a vad sejtekből álló közösség összeomlását és pusztulását eredményezi.

Bizonyos fertőzések esetén a résztvevő fajok hatással vannak egymásra, így képesek befolyásolni a fertőzés kifejlődését (lásd. 1.4. fejezet). Ennek hátterében kommunikációs átfedés is állhat, ekkor a fajok képesek értelmezni a másik faj által termelt jelmolekulákat is. A jelenséget fajok közötti szignalizációnak nevezzük [93-94]. Erre a jelenségre egy részletesen leírt példa a következő, három fajból álló rendszer: az olíva fa egyik kórokozója a Pseudomonas savastanoi pv. savastanoi (PSV). Mellette két további, nem patogén baktérium 
faj is elő szokott fordulni, nevezetesen a Pantoea agglomerans (PA) [95], valamint a Erwinia toletana (ET) [96]. Ismert, hogy a három baktériumfaj együtt gyorsabban növekszik, mint külön-külön [97]. Laboratóriumi kísérletekkel igazolták, hogy a PSV, a PA és az ET képesek egymás jelmolekuláira reagálni [97]. A három faj együttmüködésében a következő QS interakciókat lehet felírni: PSV és ET között szimmetrikus kapcsolat áll fent, vagyis kölcsönösen képesek reagálni egymás jelmolekuláira, valamint felhasználni az egymás által termelt közjavakat (8. ábra). A PSV és PV között viszont egyoldalú a kapcsolat, ugyanis a PSV képes reagálni a PV által termelt jelmolekulákra, viszont fordítva PV erre nem képes.

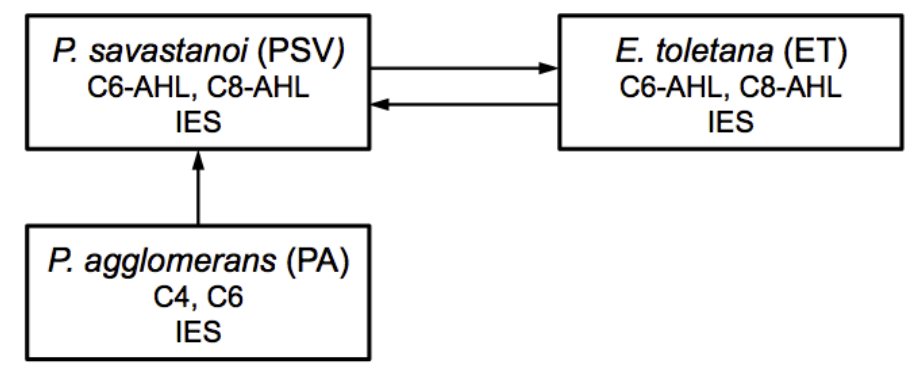

8. ábra: A bakteriális jelek és közjavak megosztása a három baktériumfaj esetében. A PSV és ET ugyanazokat az AHL molekulákat használják a QS szabályozásához: N-(3-oxo-hexanoil)-L-homoszerin lakton (C6-AHL) és N(3-oxo-oktanoil)-L-homoszerin lakton (C8-AHL), ami a szimmetrikus megosztás egy példája. A PA viszont két másik jelmolekulát termel - N-butanoil-L-homoszerin lakton (C4) és N-hexanoil-L-homoszerin lakton (C6) melyekre a PSV képes reagálni, melyre a PA nem képes. Emellett mindhárom faj termel indolecetsavat, mely a tumorképződésért felelős növényi hormon, ami által a gazdanövény tápanyagokat mobilizál a fertőzés helyszínére [97].

Általánosságban tehát szimmetrikus kapcsolatról beszélünk A és B faj között, ha a két faj képes reagálni a saját és a másik faj jelmolekuláira, vagy képesek felhasználni az egymás által termelt közjavakat (9. ábra). Aszimmetrikus kapcsolat esetén a B-vel jelölt faj reagál az A faj által termelt szignálmolekulákra, de $\mathbf{A}$ faj nem képes értelmezni a $\mathbf{B}$ által termelt jelmolekulákat, illetve $\mathbf{B}$ faj képes felhasználni az A faj által termelt közjavakat, de fordítva ez nem teljesül. Ebben az esetben B faj viszonzás nélkül kizsákmányolja a másik faj QS rendszerét.

A bemutatott háromszereplős konzorciumnak van egy további érdekessége: az indolecetsav (IES) növényi hormon termelése, mely nem QS szabályozás alatt áll [98]. Az említett hormon szerepet játszik a tumorszövet kialakulásában a gazda növényben, mely feltétele a baktériumok növekedéséhez szükséges csomó létrejöttének. Annak ellenére, hogy a PSV az elsődleges fertőző ágens - mely a másik két faj jelenléte nélkül is képes fertőzést, 
vagy tumort indukálni -, rajta kívül a másik két faj is termel IES-t, mely tekinthető közjónak [97], mellyel mindhárom faj hozzájárul a megfelelő környezet kialakításához.

1. séma

$(\mathrm{A} \rightleftarrows \mathrm{B} \bigcirc \quad$ Szimmetrikus megosztás

2. séma

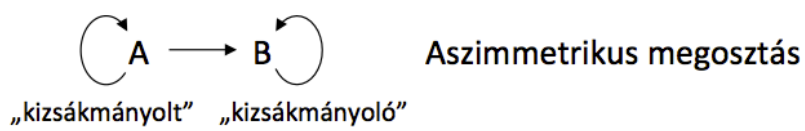

9. ábra: A jelek és közjavak fajok közötti megosztásának különböző lehetőségei a QS szempontjából. 1. Séma: Szimmetrikus megosztás: Az A és B faj kölcsönösen képesek reagálni egymás jelrendszerére, vagy képesek felhasználni az egymás által termelt közjavakat. 2. séma: Aszimmetrikus megosztás: B faj képes reagálni az A faj által termelt jelekre, vagy közjavakra, viszont A faj erre nem képes. A körkörös nyilak azt jelzik, hogy mindegyik faj képes értelmezni, ill. felhasználni a saját maga által termelt jelmolekulákat és a termelt közjavakat.

A bemutatott jelenség volt az egyik fő motivációja munkám utolsó fejezetében tárgyalt kompetíciós szimulációk vizsgálatának (lásd 4.3. fejezet). Ugyanis felmerült a kérdés, hogy vajon a jelmolekulák és a közjavak szimmetrikus, ill. aszimmetrikus megosztása mennyiben járul hozzá a bakteriális konzorciumok stabilitásához.

\subsection{Baktériumpopulációk számítógépes modelljei}

Biológiai közösségek modellezésére számos, különböző alapokon nyugvó in silico módszer létezik, melyek közül a szakirodalomban található legfontosabb példákat fogom bemutatni a következőkben. A felsorolt modellek különböző kérdések megválaszolására születtek, de mindegyiket alkalmazták baktériumkolóniák növekedésének modellezésére és jellemzésére.

\subsubsection{Kawasaki modell (reakció-diffúziós modell)}

Kawasaki és mtsai 1997-ben publikáltak egy ún. kontinuum modellt, mellyel Bacillus subtilis kolóniák Petri-csészében történő növekedését vizsgálták [99]. A rendszerben a baktériumkolóniát és a tápanyagot is diffúzibilis, folytonos egységeknek tekintették, melyek viselkedését a kémiai modellekből ismert reakció-diffúziós egyenletekkel írták le. A modell segítségével sikerült in silico reprodukálni a laboratóriumi kísérleteket, melyeknél a sejtkolóniákat különböző viszkozitású és tápanyag tartalmú Petri-csészék közepére oltották le. 
A kísérletek során a fenti paraméterektől függően különböző morfológiájú kolóniákat figyeltek meg: abban az esetben, ha az agar médium sürüsége alacsony volt, míg a tápanyag koncentráció magas, kör alakú kolóniák alakultak ki. A magasabb sürüségü táptalajon azonban egyre szabálytalanabb telepek képződtek. Továbbá, ha megnövelt sürüségü médiumban lecsökkentették a tápanyag koncentrációt, akkor elágazó kolóniákat figyeltek meg. Ezeknek a nyúlványoknak, vagy más néven dendriteknek a kialakulásának hátterében a limitált diffúzió áll, ugyanis a sűrű agar médium esetében nem áll rendelkezésre elegendő lokális tápanyag a sejtek számára. A növekedéshez szükséges tápanyagok diffúzióval jutnak el a felhasználás, vagyis a dendrit helyére a szomszédos területekről, és az így kialakult tápanyagban szegényebb régiókon nem képes növekedni a kolónia.

A nyúlványok sürüsége a táptalaj viszkozitásától függött. Mivel magasabb viszkozitású táptalajban kevésbé hatékonyan diffundál a táplálék, így kevesebb nyúlvány képződött, mint alacsonyabb agar sürüségü táptalajon. A két fő kolónia mintázatot DBM-nek (Dense Branching Morphology) és DLA-nak (Diffusion Limited Aggregation Pattern) nevezzük (10. ábra).

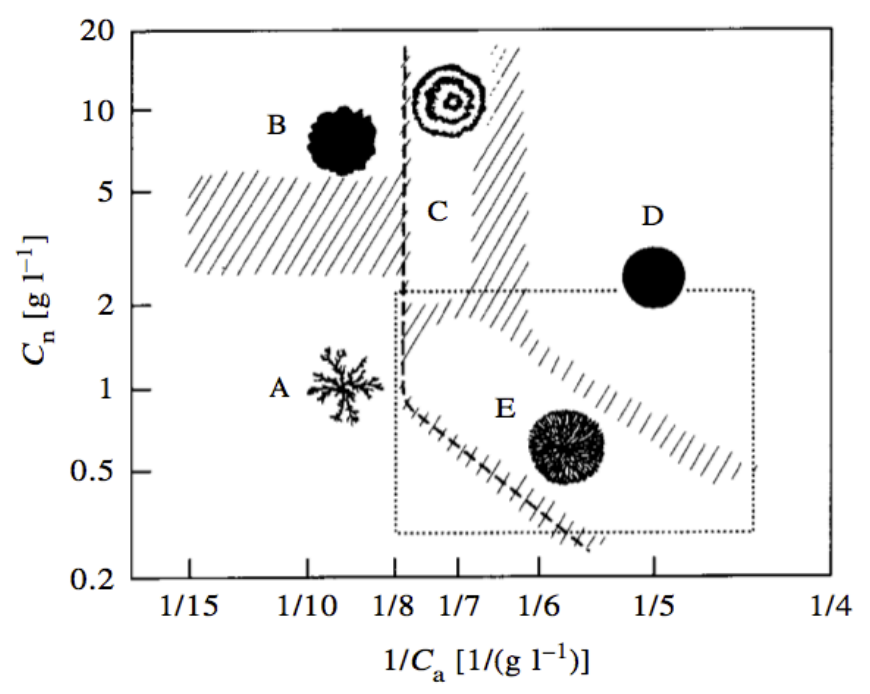

10. ábra: A különböző viszkozitású és tápanyagtartalmú médiumokon kialakult baktérium kolónia mintázatok. Az ábra vízszintes tengelyén az agar koncentráció reciproka, míg a függőleges tengelyen a tápanyag koncentrációt ábrázolták. Az „A” jelölésű kolóniatípus a tipikus DLA-ra, míg az „E” kolónia a DMB-re megfigyelhető mintázat [99].

A számítógépes rendszerben a fenti jelenséget a következő módon modellezték: a baktériumkolónia és a tápanyag egy 2D felszínen diffundált, mely diszkrét szegmensekre volt felosztva. Az idő szintén diszkretizált a rendszerben, vagyis ciklusonként számolták ki az aktuális koncentráció értékeket. 
A baktériumok koncentrációjának és a tápanyagszintnek a változását következő reakció-diffúziós egyenletekkel írták le:

$$
\begin{aligned}
& \frac{\partial n}{\partial t}=D_{n} * \nabla^{2} n-f(b, n) \\
& \frac{\partial n}{\partial t}=\nabla \cdot\left\{D_{b} \nabla \mathrm{b}\right\}+\Theta f(n, b)
\end{aligned}
$$

ahol $t$ az időt, $n$ a tápanyag koncentrációt, $b$ a baktériumpopuláció sürüségét, valamint $D_{n}$ a tápanyag, míg $D_{b}$ a baktériumok diffúziós állandóját jelölik. A szimulációk során hasonló mintázatok születtek, mint az in vitro kísérletek esetében, vagyis a kolónia morfológiája jelentősen függött a médium viszkozitásától, valamint a tápanyag koncentrációtól. A számítógépes szimulációk során kapott kolóniák a 11. ábrán láthatók.
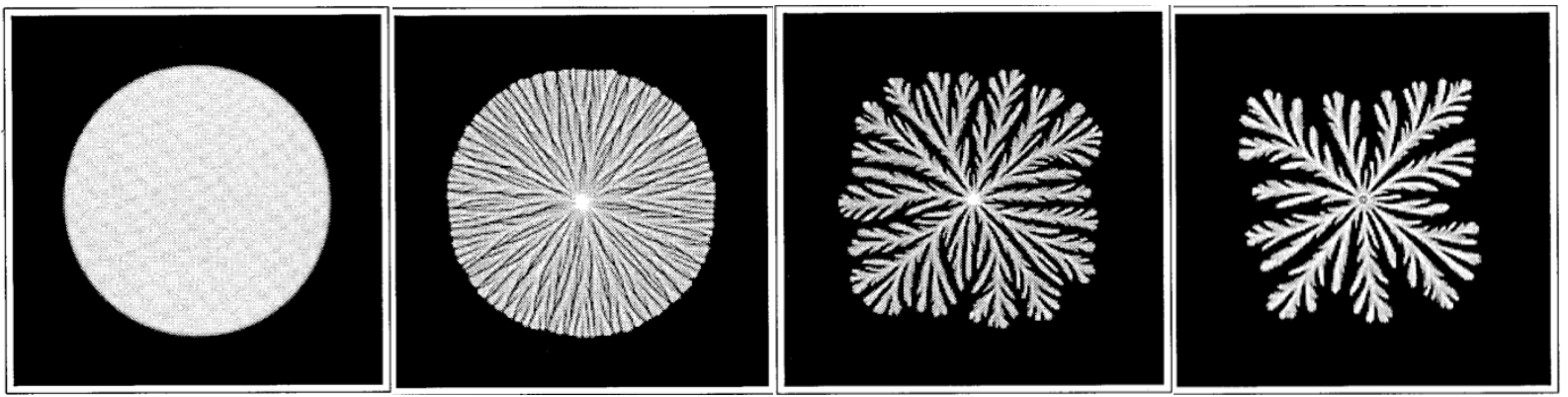

11. ábra: A Kawasaki modell eredményeként született kolóniák alakja, különböző kiindulási feltételek mellett [99]. A baloldali ábrán alacsony médium, ill. magas tápanyag koncentráció mellett kialakult kör alakú kolónia látható. Mellette, egy magasabb viszkozitású médium felületén létrejött, DBM-szerű kolónia ábrája figyelhető meg. A jobb oldali két képen az egyre csökkenő tápanyag esetén kialakult DLA kolóniákra láthatunk példákat.

A kontinuum modellek alkalmasak homogén rendszerek diffúziójának modellezésére, azonban a bemutatott Kawasaki modellben a populációt nem mint egyedek, hanem egyetlen folytonos egységként reprezentálták. Ez által a modell nem ad információt a populáció egyes egyedeinek metabolikus, vagy genetikai állapotáról.

\subsubsection{Reynolds modell (ágens alapú modell)}

A baktériumokat ábrázolhatjuk különálló, önálló döntések meghozására képes entitásokként, ún. ágensekként, melyek sokaságából épül fel a modellezett populáció. Az ágensek tényleges fizikai koordinátákkal rendelkeznek, illetve egyéb paraméterekkel is jellemezhetők, mint pl. sebesség, életkor, vagy raktározott energia. Az ágensek előre 
meghatározott eljárások szerint müködnek, azonban ezek a szabályok tartalmazhatnak sztochasztikus elemeket, ill. létrehozhatunk tanulásra képes ágenseket is, melyek hatékonyabban képesek alkalmazkodni a változó környezetükhöz [100].

Annak ellenére, hogy az ágensek különálló egyedek, a belőlük felépülő rendszer bizonyos esetekben komplexebb funkciókra képes, mint azt a különálló ágensek tulajdonságaiból és interakciójából feltételezni lehetne. A lehetséges döntéseket elöre definiáljuk, melyet tekinthetünk genetikailag örökölhető információnak abban az esetben, ha az ágens képes reprodukcióra. A multi-ágens rendszerekkel, melyekben legalább kétféle ágens szerepel egy közös környezetben, hatékonyan lehet szimulálni a kooperációs ill. kompetíciós mechanizmusokat. Ez utóbbi esetében a külön „fajba” tartozó ágensek azonos erőforrásokért (pl. táplálék, tér) versenyeznek, és többnyire kialakul egy győztes és egy vesztes faj. Kooperáció esetén viszont az ágensek együttmüködnek, ezáltal olyan funkciókat is képesek megvalósítani, melyre különálló egyedekként nem lennének képesek. Például, egy baktériumkolónia olyan területekre juthat el kollektív mozgás által, ahová az egyes egyedek önmagukban nem lennének képesek eljutni. A következőben bemutatásra kerülő ágens modell ugyan nem baktériumkolóniák növekedésének vizsgálatára lett kifejlesztve, viszont segítségével szemléletesen be lehet mutatni a modelltípus főbb jellemzőit.

1987-ben Craig W. Reynolds és mtsai. kifejlesztettek egy ágens alapú modellt, mellyel madárrajok mozgását szimulálták [101]. Ebben a modellben a madarak vagyis az ágensek saját szemszögükből érzékelték a 3D teret és a szomszédos egyedeket. Repülési irányukat és sebességüket három, előre definiált szabály szerint változtatták meg, a lokális környezetükben érzékelt információk alapján. A három szabály fontossági sorrendben a következő:

1. „ „Ütközés elkerülése (szeparáció)”: az ágensek igyekeznek elkerülni az ütközéseket azáltal, hogy nem mennek egymáshoz túlságosan közel

2. „Sebesség illesztése”: az ágensek hozzáigazítják a sebességüket a szomszédos ágensek sebességéhez

3. „Raj együttmaradása (kohézió)”: az ágensek igyekeznek együtt maradni a szomszédos ágensekkel

Az ágensek a döntéseiket tehát a fenti három egyszerü szabály alapján hozzák meg, mely eredményeként realisztikusan lehet modellezni a rajok komplex mozgását és interakcióit. A modellben, a futási idő csökkentése érdekében egy adott ágens csak limitált számú szomszédos ágens paramétereit vette figyelembe, ezáltal gyorsabban hozhattak 
döntéseket, illetve azt is lehetővé tette, hogy a raj kettéválva majd újraegyesülve kikerüljön egy fizikai akadályt. A rendszerben minden ágens egyenértékü volt, vagyis nem létezett kijelölt döntéshozó egyed, továbbá a program futása során nem befolyásolták egyik ágens mozgását sem.

Biológiai szemszögből az ágensek ideális jelöltek baktériumkolóniák, valamint a kooperáció és kommunikáció modellezésére. Segítségével vizsgálhatjuk a koordinált mozgást, illetve a fajok közötti kompetíciót.

Az ágens alapú modell fontos lépés volt a baktérium modellek fejlődésében, mivel az egyedek komoly hangsúlyt kapnak a magasabb szintü folyamatok megfigyelése mellett. Viszont a modellben nem cél a tápanyag és egyéb kémiai jelek diffúziójának megvalósítása, a Reynolds modellben nem létezik a médium számítógépes reprezentációja.

\subsubsection{Ben-Jacob modell (hibrid modell)}

Hibrid modelleket különböző modellek integrálásával hozhatunk létre. Például a makroszkópikus kontinuum modell és a mikroszkópikus ágens alapú modell egyesítésével egy olyan hibrid modellt kapunk, mely alkalmasabb lehet kolóniák viselkedésének leírására, mint a két modell külön-külön. Ebben a rendszerben a baktériumokat ágensekként reprezentáljuk, melyek a kémiai környezet (tápanyag, ill. a baktériumok által termelt anyagok koncentrációja) alapján hoznak döntéseket, míg a diffúzibilis kémiai anyagok koncentrációjának változását reakció-diffúziós egyenletekkel írjuk le.

Eschel Ben-Jacob és Vicsek Tamás csoportjai 1994-ben publikáltak egy hibrid modellt, mely segítségével kolóniák növekedését, valamint a populációban megjelenő mutációk kolóniára kifejtett hatását modellezték [102-103]. A modell alapjául szolgáló in vitro kísérletek során $P$. dendritiformis var. dendron sejtkultúrát agar médium közepére oltották le, melyből elágazó mintázatú baktérium telep képződött (12. ábra). Ha a populációban olyan mutáns baktériumok is jelen voltak, melyek nagyobb növekedési rátával rendelkeztek, a leszármazott sejtek egy jóval sürübb, legyező-szerü kolónia ágat alkottak (12. ábra).

Az említett jelenséget sikerült egy hibrid-modell (ún. „Communicating Walkers”) segítségével reprodukálni. A modellben az ágensek 2D felszínen mozogtak, mely egységnyi cellákra van felosztva. Az ágensek a metabolikus aktivitásukhoz szükséges energiát a környezetben található táplálékból fedezték. Elegendő energia felhalmozása esetén az ágensek osztódtak, energia hiányában inaktiválódtak. 


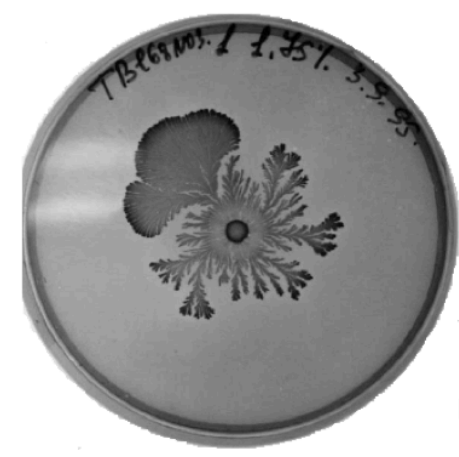

A

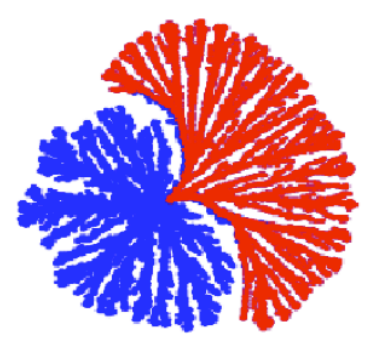

B

12. ábra: A. In vitro kísérletből származó kolónia, mely a jellemző kolónia morfológiát mutatja. A) legyező-szerü nyúlvány gyorsabban osztódó mutáns egyedekből áll. B) Az in silico modell esetében hasonló mintázatot alakult ki: a kék szín a vad típusú sejteket, míg a piros szín a gyorsabban osztódó mutánsokat jelöli [104].

Az ágensek random mozoghattak a kolónia határain belül, viszont ha egy ágens megpróbálta átlépni a kolónia határát, akkor mozgás nem valósult meg és a rendszer rögzítette a próbálkozást. Elegendő próbálkozás esetén az adott cella is a kolónia tagjává vált, melybe bármelyik ágens léphet. Ezzel a megoldással lehet modellezni a kolónia által termelt "kooperációs faktorok" (pl. nyálkaanyagok) jelenlétét, melyek szükségesek a kolónia terjeszkedéséhez. A modellben a termelt kémiai anyagok, valamint a táplálék diffúzióját a Kawasaki modellből is ismert reakció-diffúziós egyenlettel analóg módon írták le.

A sejtek osztódását a következő módon valósították meg: az ágensek rendelkeztek belső energiaszinttel, ami függött a sejtek környezetétől és a belső metabolizmusuktól: a tápanyagfelvétel által a sejtek energiaszintje növekedett, amely ha elért egy küszöbszintet, akkor osztódás következett be. A belső energia változását a 3. egyenlet írja le:

$$
\frac{d E_{i}}{d t}=\kappa * C_{\text {consumed }}-\frac{E_{m}}{\tau_{R}}
$$

ahol $E_{i}$ az $i$. ágens energiaszintje, $C_{\text {consumed }}$ az ágens tápanyagfogyasztásának, valamint a rendelkezésre álló tápláléknak a minimuma, $\kappa$ a tápanyag energiává alakítását, $\tau_{R}$ a reprodukciós időt, míg $E_{m}$ a bekövetkezett energiaveszteséget írja le.

A bemutatott Ben-Jacob-féle hibrid modell az ágensek és a kémiai környezet szeparált modellezése miatt optimális választás lehet quorum érzékelés modellezésére. Ezért ezt a rendszert vettük alapul a saját hibrid modellünk felépítéséhez. 


\subsubsection{Gerlee modell (sejtautomata modell)}

A sejtautomata fogalmát Neumann János vezette be az 1950-es években [105]. A sejtautomaták általában négyzetrácsba, vagy hatszögbe rendezett cellákból (ún. sejtekből) állnak, melyek különféle, véges állapotokkal rendelkeznek. A sejtautomata celláinak állapota ciklikusan frissül a meghatározott szabályok szerint. Az egyes sejtek állapota többnyire az adott sejt, illetve a szomszédos sejtek előző állapotától függ.

A sejtautomaták egy konkrét biológiai megvalósítása a Gerlee és mtsai. által 2007-ben publikált modell, mely segítségével sikerült a már korábban is bemutatott jellemző növekedési mintázatokat reprodukálni [106]. A koncepció, melyet a baktériumok reprezentációjára alkalmaztak, jelentősen eltér az eddigi modellekben használt megoldásoktól: egy 2D felszínt $N^{*} N$ cellára osztották fel, melyek három állapotot vehettek fel: lehettek üresek, ill. tartalmazhattak aktív, vagy inaktív sejteket. A táplálék diffúzióját minden iterációs lépésben reakció-diffúziós egyenlet írta le. A baktériumok a táplálékfogyasztással fedezték az osztódáshoz szükséges energiát, mely ha egy kritikus szint alá csökkent, akkor a sejtek inaktiválódtak. Osztódás során az utódsejt egy szomszédos cellába került, továbbá mindkét sejt életkora nullázódott. A szimulációk eredményeképpen hasonló telepmintázatok születtek, mint a korábbi modellek esetében. A morfológia a sejtek tápanyagfelvételétől függött: alacsony tápanyagfogyasztás esetén kör alakú kolóniák képződtek, míg a sejtek tápanyagfelvételének fokozásával fraktálszerü telepek alakultak ki (13. ábra).
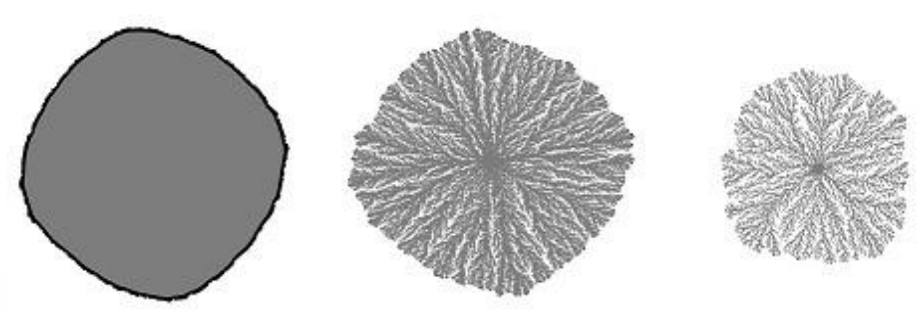

13. ábra: A Gerlee modell által keletkezett baktériumtelepek morfológiája. Bal oldalon alacsony tápanyagfelvételü sejtekböl kialakult, kör alakú kolóniát láthatunk. Középen, ill. jobb oldalon egyre növelték a sejtek tápanyagfelvételét, így kialakultak a fraktálszerü dendritek [106].

A bemutatott modellekkel sikeresen lehet in silico reprodukálni a különféle kolóniamorfológiákat, de ezek a modellek önmagukban nem alkalmasak a quorum érzékelés szimulációjára. A kontinuum modellekből hiányzik a sejtek egyed szintű reprezentációja, illetve az ágens alapú modellek esetében a sejtek egyrészt nem rendelkeznek megfelelő belső 
szabályrendszerrel, másrészről nincsenek dinamikus kapcsolatban környezetükkel a tápanyagfelvételen kívül. A quorum érzékelés hatékony modellezéséhez azonban szükség van újabb, a sejtek által termelt kémiai komponensek, a kommunikációs jel és a közjavak reprezentációjára, melyek szabadon diffundálnak a környezetben. Így munkánk során egy olyan hibrid ágens modellt fejlesztettünk ki, mely egy kvalitatív szempontból helyes quorum érzékelési modellnek tekinthető [107]. A modell részletes bemutatására az Módszerek 3.4. fejezetében kerül sor.

\subsection{A quorum érzékelés laboratóriumi modelljei}

$\mathrm{Az}$ in silico modellek mellett említést érdemelnek az alapvető laboratóriumi módszerek is, melyek nélkül nem lehetne behatóan vizsgálni a mikrobiális közösségeket. Fontos megjegyezni, hogy a laboratóriumi in vitro rendszerek is csak modellek, amelyek a vizsgált rendszer - tehát a természetben élő baktériumközösségek - viselkedését csak nagyon korlátozott körülmények között modellezi. A homogén, steril körülmények közötti növekedés ugyanis nyilvánvalóan távol áll a strukturált környezetben, változó természeti körülmények között lezajló reális folyamatoktól. Ráadásul, a QS baktériumok jellemző módon változtatják életmódjukat, pl. meg kell élniük egy rovar-vektor felületén vagy tápcsatornájában, majd meg kell élniük egy növény tápcsatorna hálózatának mikrofluidikai körülményei között is. Két alapvető sejttenyésztési technika áll rendelkezésre a QS vizsgálatára: a folyadékkultúra és a szilárd agar médium.

Folyadékkultúrák esetében tápanyagban és ásványi anyagokban gazdag LB ('Lysogeny Broth') oldatban növesztjük a sejteket, melyben a kritikus sejtkoncentrációt elérve bekapcsolnak a QS által szabályzott gének. A rázatott folyadékkultúrában a sejtpopuláció mérete a mikrobiológiában jól ismert szigmoid növekedési görbével jellemezhető, mely a következő fázisokra tagolható: lag fázis, log fázis, stacionárius fázis és regressziós fázis. Mindegyik növekedési fázisnak jellemző génexpressziós mintázata van. A QS génjei jellemzően a késői log fázisban, ill. a stacionárius fázis elején expresszálódnak.

Speciális, erre a célra fejlesztett szilárd táptalajon lehetőségünk van a rajzó kolóniák vizsgálatára. A rajzó mozgás egy rendkívül érzékeny, QS által szabályozott folyamat, amihez alacsony agar $(0.5 \%)$ és glükóz $(0.2 \%)$ tartalmú táptalajra van szükség. A médium pontos összetétele a Függelék 1. táblázatában található. A táptalajok közepére egy éjszakán át növesztett (ún. "overnight") sejtkultúrát csöppentve néhány óra inkubáció után beindul a 
rajzás folyamata, mely speciális morfológiájú, az átlagosnál jóval gyorsabban növekedő kolóniákat hoz létre (lásd 1.3.3. fejezet, 5. A ábra).

A bemutatott technikák mellett további, speciális eszközök állnak rendelkezésünkre, melyekkel vizsgálhatjuk a QS mechanizmusát. Mikrofluidikai eszközökben sejt szinten vizsgáljuk a QS jelenségeket, kontrollált jelkoncentráció és egyéb környezeti paraméterek mellett. Továbbá, lehetőség nyílik arra, hogy QS által szabályzott folyamatokat elválasszuk a sejtsűrüségtől, mivel ezekben a rendszerekben a kolóniától, illetve annak sürüségétől függetlenül vizsgálhatjuk a különböző QS körök müködését.

Számos mikrofabrikációs technika áll rendelkezésre QS jelenségének vizsgálatára, mint pl. áramlásos mikrocsatorna rendszer [108], víz-olaj emulziós rendszer [109], valamint mikroárok modellek [110]. Az utóbbi két rendszerben a csapdázott sejtek rendkívül kis térfogatban helyezkednek el, így az általuk termelt jelmolekula hamar eléri a küszöbkoncentrációt. Ezáltal a sejt azt fogja érzékelni, hogy a populáció mérete elérte a kritikus szintet és expresszálja a QS szabályzás alatt álló géneket. 


\section{Célkitüzések}

Vizsgálataink során az alábbi célkitűzéseket fogalmaztuk meg:

- Egy egyszerüsített, ágens alapú hibrid modell létrehozása, mely alkalmas a $P$. aeruginosa (vad típusú, ill. különböző QS deléciós mutánsok) quorum érzékelés által szabályzott rajzásának kvalitatív modellezésére.

- P. aeruginosa törzsek rajzásának in vitro és in silico vizsgálata exogén jel jelenlétében és hiányában.

- Stabilis közösségek kialakulási feltételeinek tisztázása.

- A modell továbbfejlesztése a jelanyag és a közjó fajok közötti megosztásának, ill. annak következményeinek vizsgálatára.

- A QS jeleket, kooperációs faktorokat és a táplálékot különböző mértékben megosztó baktériumtörzsek együtt-rajzásának in silico vizsgálata, mely segítségével választ kaphatunk arra, hogy a baktériumtörzsek közötti különböző mértékủ kommunikáció és a kooperáció milyen hatással van a populáció stabilitására és átlagos fitneszére. 


\section{Módszerek}

\subsection{Baktériumtörzsek és a sejttenyésztés körülményei}

A kísérletek során használt $P$. aeruginosa PUPa3 törzset rizs riszoszférájából izolálták Indiában [111]. A vad típusú ('Wild Type', WT) törzsben mindkét QS rendszer, vagyis a LasI/R és RhlI/R is megfelelően funkcionál (14. ábra).

A két QS rendszer szempontjából többféle mutáns törzs állítható elő a szintáz gének (lasI, rhlI), illetve a transzkripciós regulátor fehérjék termeléséért felelös gének (lasR, rhlR) inaktiválásával. Azokat a null mutánsokat, melyekben mindkét szintáz, ill. regulátor rendszer inaktív, rendre SN ('Signal Negative', $\Delta l a s I / r h l l)$ és SB ('Signal Blind', $\Delta l a s R / r h l R$ ) törzseknek nevezzük.
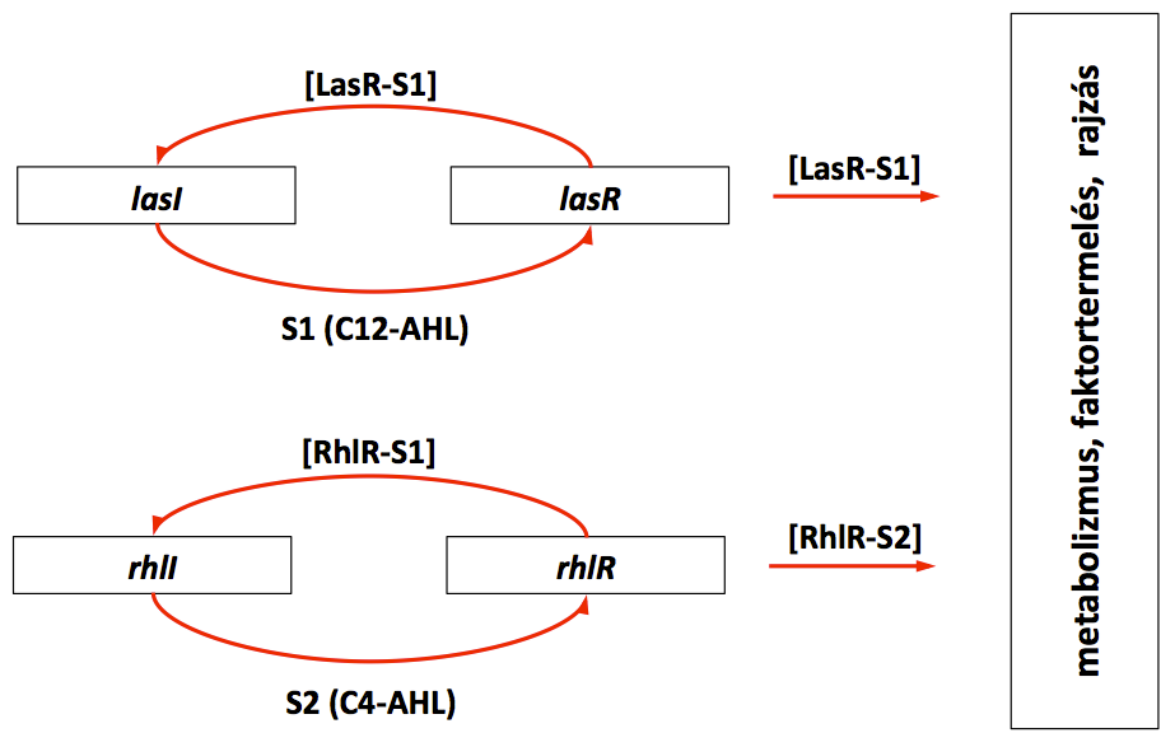

14. ábra: A P. aeruginosa lasI/R és rhlI/R rendszerének sematikus felépítése. A piros nyilak a génaktivációt jelölik.

A kísérletek során használt QS deléciós mutánsokat a 2. táblázatban foglaltam össze. A mutáns törzseket inszerciós inaktivációval készítettük el Steindler és mtsai. munkája alapján [112].

A rajzási kísérletek során M8 agar médiumot használtunk, mely az $\mathrm{M} 9$ médium $\mathrm{NH}_{4} \mathrm{Cl}$ mentes változata [111]. A táptalaj $0.5 \%$ agart, $0.2 \%$ glükózt és $0.05 \%$ glutamint tartalmaz (lásd Függelék, 1. táblázat). A szabványos méretü ( 90 mm átmérőjű) Petri-csészékbe kiöntött, majd megszilárdult táptalaj közepére baktérium szuszpenziót oltottunk $(0.5 \mu 1)$, melyeket $30^{\circ} \mathrm{C}$-on inkubáltunk a rajzás ideje alatt. A kísérletek során használt C4-AHL és C12-AHL 
molekulákat a Sigma-Aldrich cégtől rendeltük, melyeket $2 \mu \mathrm{M}$ koncentrációban adtunk a táptalajhoz.

2. táblázat: A kísérletek során használt különböző QS null mutáns törzsek rajzási fenotípusainak összefoglaló táblázata. A $\Delta$ rhlR és SB mutánsok hozzáadott jel esetében sem képesek rajzó mozgásra, mivel nem rendelkeznek receptorfehérjével, melyhez a jelmolekulák kötődnek.

\begin{tabular}{ll}
\hline Mutáns törzs & Rajzási fenotípus \\
\hline$\Delta l a s I$ & önálló rajzás \\
$\Delta l a s R$ & önálló rajzás \\
$\Delta r h l I$ & rajzás csak hozzáadott jel esetén \\
$\Delta r h l R$ & nem képes rajzásra \\
SN $(\Delta l a s I / r h l l)$ & rajzás csak hozzáadott jel esetén \\
SB $(\Delta l a s R / r h l R)$ & nem képes rajzásra \\
\hline
\end{tabular}

\subsection{A hibrid modell implementálása}

A Netotea-féle hibrid rendszer [107] első verziója Java programozási nyelven íródott, melyet a későbbiekben MATLAB programozási környezetben fejlesztettünk tovább. A két verzió ugyanazon algoritmus alapján müködik, viszont a MATLAB verzió tervezése során kiemelt figyelmet fordítottunk a forráskód optimalizációjára, mely által a szimulációk is gyorsabbak lett. Az új keretrendszerrel hatékonyabban lehet kezelni a nagyméretü adatstruktúrákat, valamint az optimalizált függvényekkel rövidebb idő alatt kaphattunk eredményt ugyanarra a szimulációra, amit a Java verzióban is lefuttattunk. Emellett a MATLAB-ban lehetőségünk nyílt párhuzamos futtatásra is, mely komoly elönyt jelentett számos szimuláció futtatásakor. Az adatok kiértékelése is egyszerübb volt a MATLAB-ban, mivel előre megírt és tesztelt függvényeket használhattunk az adatok feldolgozása során.

\subsection{A szimulációk hardveres környezete}

Egy átlagos szimuláció 10-20 perc alatt lefutott akár egy átlagos teljesítményü asztali PC-n is, viszont a paramétertér hozzávetőleges feltérképezéséhez több száz szimulációt kellett szisztematikusan lefuttatni. Ehhez a trieszti ICGEB-ben található számítógép klasztert használtuk. A linux klaszter egy darab frontend kiszolgálóból és 20 darab backend gépből állt, melyek mindegyike $2.2 \mathrm{GHz}$-es processzorokkal és 2 GB memóriával rendelkezett. Így a klaszteren párhuzamosan $20 \mathrm{db}$ szimulációt futtathattunk, így kevesebb, mint 24 óra alatt lefutott egy köteg szimuláció (726db szimuláció, egyenként max. 40000 lépéssel, lásd 4.3.1. fejezet). 


\subsection{A modell bemutatása}

A következőkben ismertetni fogom, hogyan modelleztük a közösséget alkotó baktérium sejteket, a velük kölcsönhatásban lévő környezetet, továbbá a rendszerben lezajló kémiai jelenségeket. A fejezet végén pedig bemutatom a kiértékelésénél alkalmazott legfontosabb módszereket.

\subsubsection{A baktériumok modellezése}

Modellünkben a $P$. aeruginosa sejteket random mozgást végző, pontszerű ágensekként reprezentáljuk, melyek kölcsönhatásban vannak a környezetükkel az általuk termelt kémiai ágensek, valamint a tápanyag felvétele révén. A populáció tagjai döntéseiket önállóan, egymástól függetlenül hozzák meg a környezetben lévő kémiai anyagok koncentrációja alapján. A modellben az ágensek csak egyetlen quorum rendszerrel rendelkeznek, és csak egyféle jelmolekula (S - "Signal") segítségével kommunikálnak egymással, amely megfeleltethetö a $P$. aeruginosa C4-AHL és C12-AHL jelmolekuláinak (15. ábra). A quorum állapot elérésekor, vagyis ha a szignálmolekula koncentrációja meghalad egy bizonyos küszöböt, a baktériumsejtek a "genetikai programjuknak" megfelelően különböző anyagokat kezdenek termelni (pl. felületaktív rhamnolipid, sziderofórok, különféle toxinok, antibiotikumok és proteázok), melyeket szintén egyetlen általános kooperációs faktorként (F "Factor") modellezünk. A faktor küszöbkoncentrációjának elérésével indul be a rajzás jelensége, mely során jelentősen megváltozik a sejtek metabolizmusa és mozgási intenzitásása.

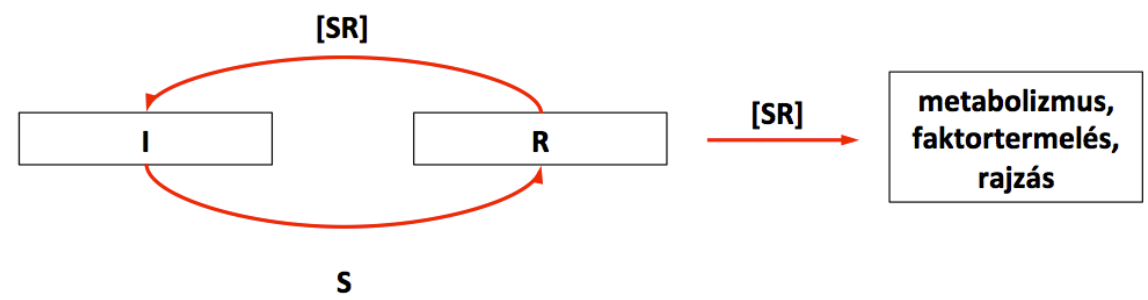

15. ábra: Az ágens modell egyszerüsített QS rendszere: I: indukciós fehérje, mely a S (jelmolekula) elő́llításáért felel. R: receptor fehérje. SR: jel-receptor komplex, mely a kritikus koncentrációt elérve megváltoztatja az ágensek aktivitását. A piros nyilak az elméleti modellben az aktivációt jelölik, mely hatására az ágensek állapotot váltanak.

Ezek alapján a modellben az ágensek három állapotot vehetnek fel a környezetben található jel és faktor koncentrációknak megfelelően: alapállapotban (planktonikus állapot) az 
ágensek kis mennyiségben jelmolekulákat termelnek, továbbá alacsony metabolizmussal és mozgási intenzitással jellemezhetők. A populáció sürüségével arányosan nő a jelkoncentráció is, mely ha eléri a küszöbkoncentrációt, akkor az ágensek aktivált állapotba kerülnek és megkezdik a faktor termelését. Ha a jel és a faktor koncentrációja is küszöb feletti, akkor az ágensek a metabolikusan aktív, rajzó állapotba kerülnek (lásd 1.3.3. fejezet), mely a mozgási sebesség növekedését jelenti (16. ábra).

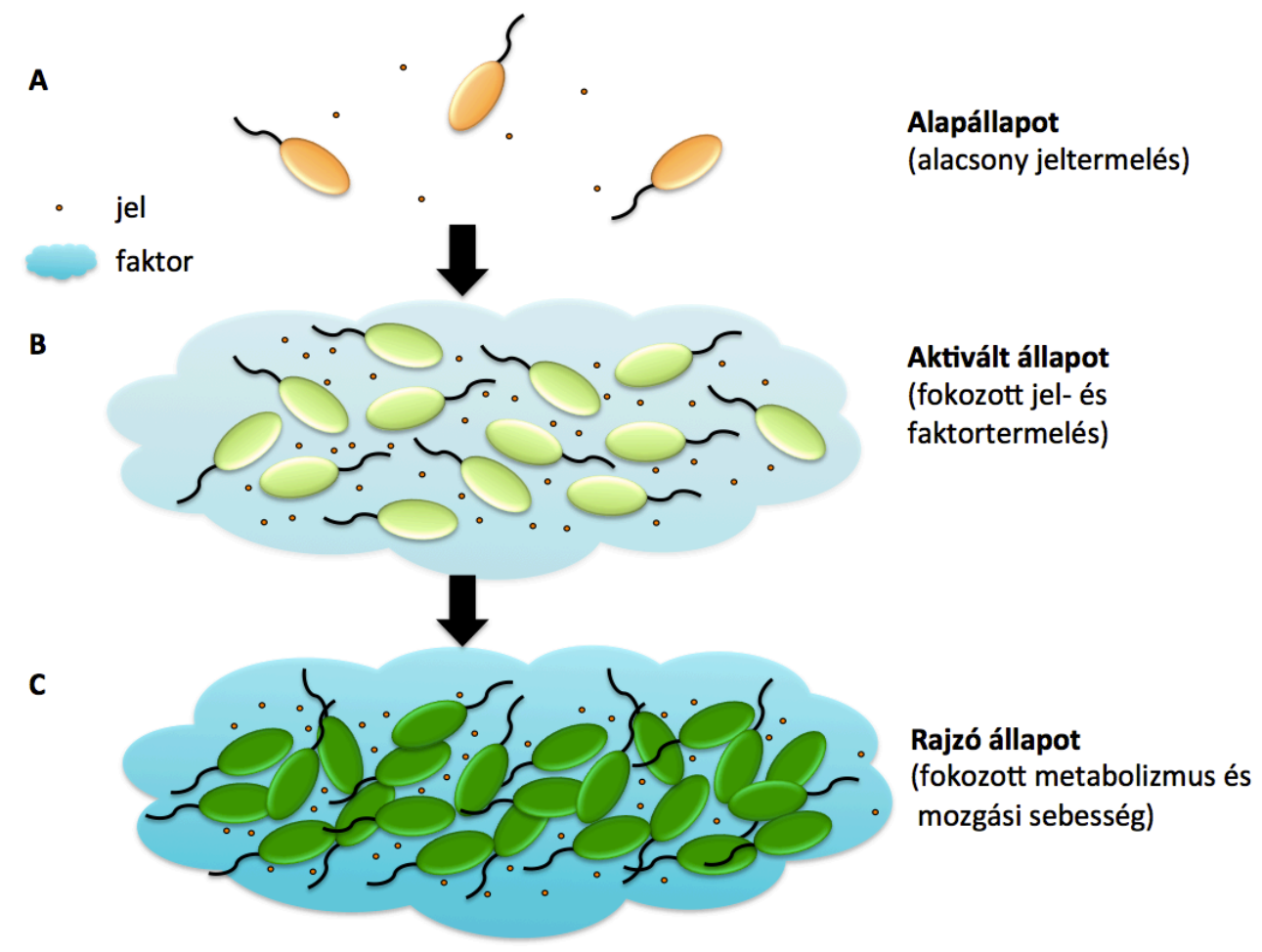

16. ábra: Az ágensek három állapota, melyek a környezetben található jel és faktor koncentrációtól függnek. Alapállapotban (A) a jel és faktor koncentráció küszöb alatti. Ha a jelkoncentráció eléri a küszöböt, akkor az ágensek aktivált állapotba kerülnek (B). Ha a jel és faktor koncentráció is küszöb feletti, akkor az ágensek rajzó állapotba kerülnek, mely fokozott metabolizmussal és megnövekedett mozgási sebességgel jár (C).

$\mathrm{Az}$ ágens modellben is létrehoztuk a laboratóriumi kísérletekél használt törzsek modelljeit, melyek egyetlen QS rendszerrel rendelkeznek: a WT ágensek képesek S és F termelésre, valamint reagálni azokra. Az SN mutáns ágensek viszont bár képesek $\mathrm{F}$ termelésére, nem képesek jelmolekulát előállítani. Az SB mutánsok képesek S termelésre, viszont soha nem állítanak elő F-et.

Mivel a baktériumsejtek kémiai anyagokat termelnek és mozgást végeznek, mely folyamatok energiát emésztenek fel, szükség volt egy egyszerü metabolikus modellre, ami a következőképpen írható le: az ágensek a szimuláció minden lépésében állapotuktól függő mértékben energiát vesznek fel a környezetükből, táplálék formájában. Ennek az energiának 
egy részét extracelluláris anyagok termelésére, metabolikus folyamatokra, valamint mozgásra fordítják, a fennmaradó részt pedig elraktározzák. $t=0$ időpillanatban a populáció egyedeinek raktározott energiája véletlenszerüen meghatározott. Az eneriga állapot változását a következő egyenlettel írhatjuk le:

$$
\mathrm{E}(\mathrm{t}+1)=\mathrm{E}(\mathrm{t})+\mathrm{E}(\text { food })-\mathrm{E}(\mathrm{S})-\mathrm{E}(\mathrm{F})-\mathrm{E}(\text { metabolism })
$$

ahol $E(t)$ és $E(t+1)$ az ágens energiaszintje $t$, ill. $t+1$ időpillanatban. $E(S)$ és $E(F)$ a szignál és faktor termelésére fordított energiát jelöli, míg az E(metabolism) az ágensek alapanyagcseréjére utal. Ha elegendő táplálék van a környezetben, akkor az ágensek minden lépésben elraktározzák a felvett és az elhasznált energia közötti különbséget. Ha ez a raktározott energia elér egy bizonyos küszöbszintet, akkor osztódás történik, mely során két alapállapotú ágens keletkezik. Természetesen az osztódás csak akkor következik be, ha elegendő hely áll rendelkezésre a két utódágens számára (lásd 3.4.2. fejezet). Ha a szimuláció során az ágensek környezetében elfogy a táplálék, vagyis nem képesek további energiát felvenni, akkor a tárolt energia felélése után az ágensek inaktiválódnak és nem vesznek részt a program további müködésében.

\subsubsection{A tér és a környezet modellezése}

Modellünkben a teret téglalap alakú felszínnel reprezentáljuk, mely folyamatos kölcsönhatásban van az ágensekkel, továbbá lehetőséget biztosít azok felszíni mozgására.

Ennek a "szimulációs térnek" ('racetrack') a két hosszanti oldalán periodikus határfeltételt alkalmazunk, vagyis ha egy ágens a random mozgásának következtében megpróbál kilépni a szimulációs tér egyik oldalán, akkor ugyanaz az ágens átkerül a tér szemközti oldalára, így az ágensek gyakorlatilag nem képesek elhagyni a felszínt (17. ábra). A szimulációs tér a start vonalon zárt, melyet az ágensek nem képesek átlépni.

A fent leírt felszín a periodikus permfeltételek miatt lényegében egy hengerpalástnak felel meg, amely egyik irányban végtelen hosszúságú. Ez az elrendezés a kolóniák nyúlványainak modellezésére szolgál, így "dendrit modellnek" nevezzük (17. ábra). Ezek a nyúlványok ugyanis valóban közel állandó szélességü alakzatok, melyek egy irányban növekednek. A szimulációs tér felszínét egységnyi élhosszúságú négyzetekre osztjuk, melyek a reakció-diffúziós modell megoldásához szükségesek (lásd 3.4.3. fejezet). Továbbá, a 
cellánkénti sejtszám korlátozásával elkerülhetjük, hogy túlzottan nagy sejtsűrüség alakuljon ki a modell táptalajon. Modellünkben cellánként max. $10 \mathrm{db}$ ágens tartózkodhat.
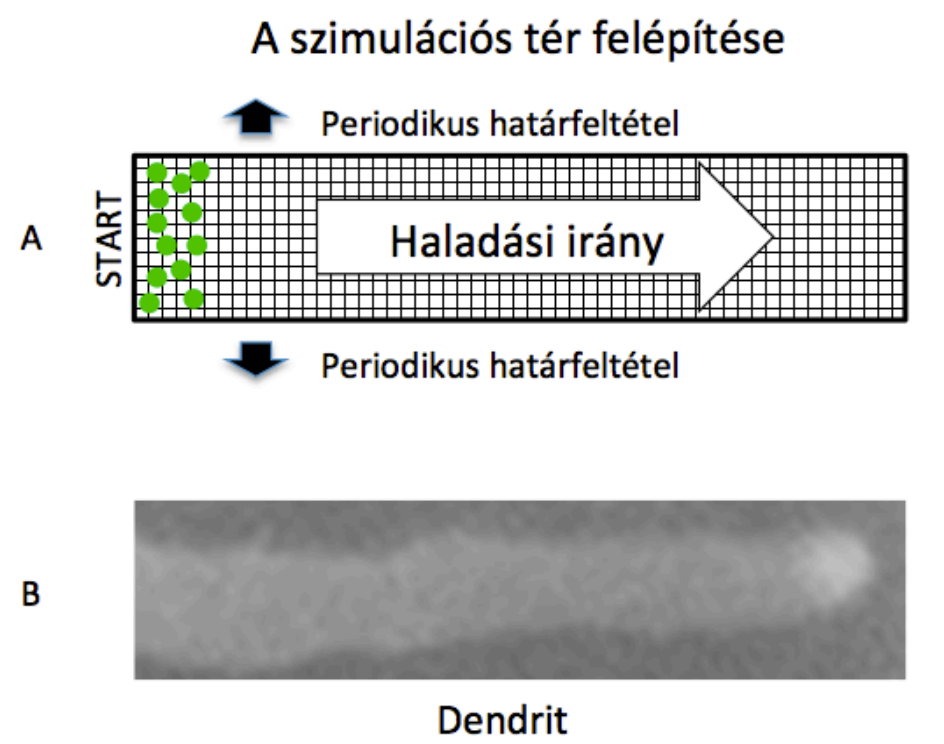

17. ábra: A) Az agar felszín modellje, mely célja egy baktérium kolónia nyúlvány kialakulásának értelmezése (dendrit modell). Kiinduláskor a zöld korongokkal jelölt ágenseket a szimulációs tér elejére helyezzük, melyek a szimuláció indításakor a táplálékban gazdag terület irányába fognak haladni. A felszín két hosszanti oldalán periodikus határfeltétel érvényesül. B) Egy rajzó dendrit ág mikroszkópos felvétele.

Mikroszkópos felvételeken jól látszódik, hogy a rajzó baktérium kolónia egy felületaktív anyagot választ ki, ami a felszínt síkosítja. Ezen a jól definiált határral rendelkező, nedves területen rajzanak a sejtek (lásd 1.3.3. fejezet, 5. B ábra). A "kolónia határt" a következő módon modelleztük: az ágensek csak olyan cellákat vehetnek birtokba a szimulációs térben, melyek egy "virtuális határon" belül helyezkednek el. A szimuláció kezdetén az ágensek a számukra kijelölt cellákban helyezkednek el a startvonal mentén. A szimuláció során folyamatosan terjeszkedik a kolónia határa a következő szabály alapján: minden cellához tartozik egy egyedsürüséget leíró változó, mely értéke abban az esetben növekszik, ha a szomszédos cellából megpróbál rálépni egy ágens a vizsgált cellára, melynek faktor koncentrációja nagyobb, mint 0 . Ha egy adott cella változójának értéke elér egy küszöbértéket („,border advancement threshold”, lásd. Függelék 2. táblázat), akkor onnantól kezdve azt a cellát is birtokba vehetik az ágensek. Ha viszont a cella változója küszöbérték alatti, akkor az ágens pozícióváltása meghiúsul. 


\subsubsection{A diffúzió modellezése}

A laboratóriumi kísérletek során a rajzó $P$. aeruginosa kolóniákat $0.5 \%$ koncentrációjú agar táptalajon növesztik. Ebben a közegben a jelmolekulák, a termelt faktorok, valamint a táplálék is képes diffundálni, modellünkbe tehát be kellett építeni a diffúzió folyamatát is. A diffúzió modellezésére számos implicit és explicit módszer létezik [113]. A hibrid modellünkben mi egy véges elem módszereknél ismert közelítést alkalmaztunk.

Modellünkben az általános reakció-diffúziós modellt használtuk, mely a kémiai anyagok térbeli koncentráció változása mellett figyelembe veszi a kémiai reakcióik hatására bekövetkező mennyiségi változásokat is. A reakció-diffúziós rendszert a következő lineáris parciális differenciálegyenlettel írhatjuk le:

$$
\frac{\partial u}{\partial t}=D \nabla^{2} u-R u
$$

ahol $D$ a diffúziós koefficiens, $u$ az anyag koncentrációja, $R$ pedig a bomlási állandó. A modellben a tápanyagot kémiailag stabilnak tekintjük, ezért annak bomlási állandója 0 . A szignál és a faktor viszont a szabad diffúzió mellett idővel lebomlik, ezért azok bomlási állandója nagyobb, mint 0 (a modellben használt bomlási állandókat lásd a Függelékben).

Ahogy azt az előző alfejezetben ismertettük, az egyenlet megoldásához a szimulációs tér felszínét diszkrét cellákra osztjuk fel, melyekben az adott anyag eloszlását egyenletesnek tekintjük. Továbbá, a szimulációs tér két szélén alkalmazott periodikus határfeltételt is figyelembe vesszük a számítások során.

A modell első verziójában a reakció-diffúziós egyenletet numerikusan a Runge-Kutta módszerrel oldottuk meg, mely hosszabb szimulációk esetében a számolási időt jelentősen megnövelte. Ezért szükségünk volt egy olyan módszerre, amely hasonlóan pontos eredményt ad, viszont erőforrás igénye jelentősen kisebb. A későbbi modellünkbe a tesztelések alapján végül az Euler-módszert választottuk, mely egy feltételesen stabil explicit numerikus módszer. Az általánosan használt Euler-módszer viszonylag pontosan közelíti a megoldást és a többi, általunk tesztelt módszerhez képest lényegesen gyorsabban kaptunk végeredményt. A megoldás a következő egyenlettel írható fel:

$$
y_{n+1}=y_{n}+h * f\left(x_{n}, y_{n}\right) \quad n=0,1, \ldots N-1
$$

ahol $y$ a keresett megoldás, $h$ a lépésköz, $f$ pedig a derivált függvény. 
A reakció-diffúziós egyenlet megoldásának gyorsabb közelítése által a szimulációk futási ideje hozzávetőleg egy nagyságrenddel csökkent az eredetileg használt Runge-Kutta módszerhez képest.

\subsubsection{A program algoritmusa és müködése}

A szimuláció kezdetén meghatározott számú, alapállapotú ágenst helyezünk el véletlenszerüen a startvonal közelében. A program ciklikusan müködik, és mindegyik iterációban az ágensek adott hosszúságú lépést tesznek meg a felszínen véletlen irányba, valamint táplálékot fogyasztanak és kémiai anyagokat termelnek az aktuális állapotuknak megfelelően. Továbbá, minden ciklusban végrehajtjuk a diffúziós eljárást a táplálékra és a termelt anyagokra.

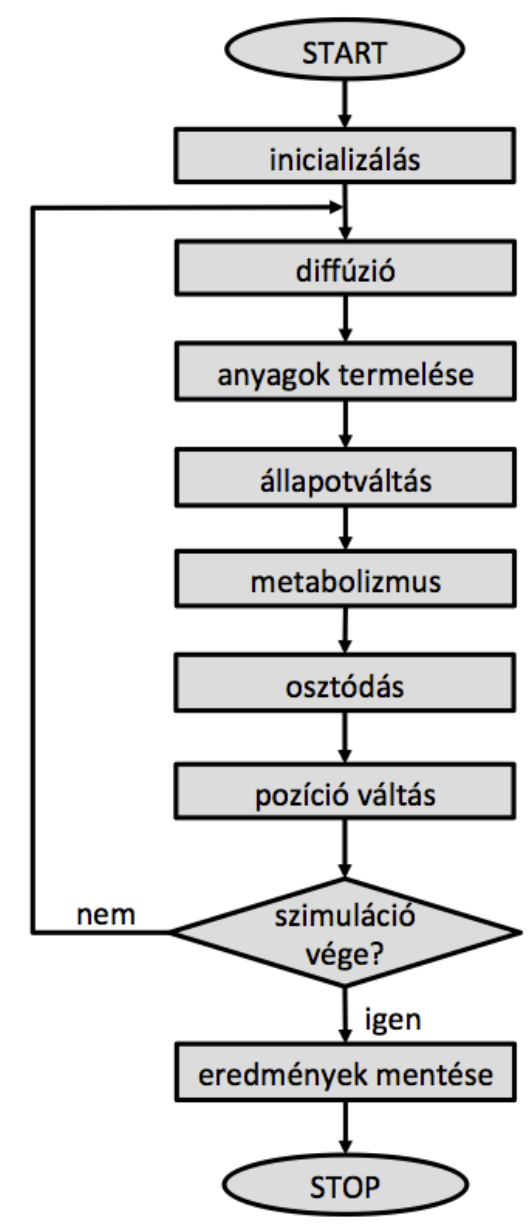

18. ábra: A program müködésének folyamatábrája. A főciklusnak két kilépési feltétele van: vagy az összes ágens inaktiválódott, vagy a főciklus eléri a maximális lépésszámot. 
A ciklusok során az ágensek érzékelik a környezetüket és a korábban ismertetett módon állapotot váltanak a körülményektöl függően. A szimuláció akkor áll le, ha az összes ágens inaktiválódott a kolóniában, vagy ha a föciklus eléri a felhasználó által megadott maximális lépésszámot (18. ábra).

Olyan kolóniák modellezése esetén (pl. WT sejtek), melyek képesek stabil rajzó populációt kialakítani, a szimuláció során spontán kialakul egy ún. aktív zóna, melyben a küszöb feletti jel és faktor koncentráció miatt az ágensek rajzó állapotban vannak. Ez a zóna az állandósult (stacioner) állapot elérése után egyenletes sebességgel halad a tápanyagban gazdag régió irányába a maximális lépésszám eléréséig (19. ábra). Ez egyensúlyi állapotnak tekinthető, mivel hozzávetőleg ugyanannyi ágens keletkezik egységnyi idő alatt, mint amennyi ágens a zóna startvonalhoz közeli felén inaktiválódik a tápanyaghiány miatt, tehát a populáció nagysága közel állandó.

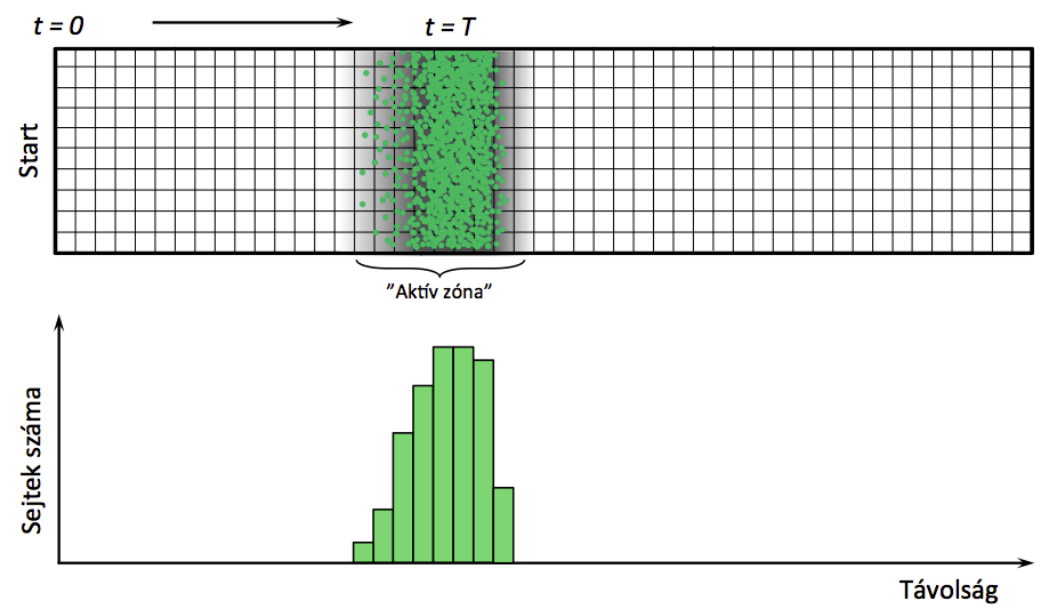

19. ábra: A szimuláció során kialakuló ún. aktív zónában az ágensek (zöld pontok) nagy része rajzó állapotban van, mivel a jel és faktor koncentrációja meghaladja a küszöbszintet. Az így kialakult rajzó kolónia egyenletes sebességgel halad a tápanyagban gazdag régió felé.

Az Függelék 2. táblázatában találhatók a szimulációkban használt legfontosabb paraméterek, melyek többsége szimbólikus, vagyis nincsenek tényleges, fizikailag mérhető értékekkel kalibrálva. A modellel végzett szimulációk elsősorban kvalitatív eredményeket adnak, melyekböl különböző tendenciákra következtethetünk.

\subsubsection{Az eredmények feldolgozása}

A következőkben röviden kitérnék azokra a specifikus modell elemekre, melyeket a két fajból álló közösségek kommunikációjának és kooperációjának modellezése során 
használtunk fel a (lásd 4.3. fejezet) . Elsőként bemutatom, hogyan modelleztük a fajok közötti jel, faktor és táplálék megosztást, mely alapján egy 3D paraméterteret térképezhettünk fel szisztematikusan. Utána bemutatnám a két legfontosabb paramétert, melyekkel numerikusan jellemezhettük a szimulációk kimeneteleit. Továbbá, ismertetni fogok egy ábrázolási módszert, mellyel hatékonyan lehetett szemléltetni a szimulációk legfontosabb eredményeit a fentebb említett 3D paramétertérben.

\section{A jel, faktor és táplálék megosztásának modellezése}

A laboratóriumi monokultúrák esetében, ahol csak egyetlen faj tartózkodik a táptalajon, a jel, a faktor és a táplálék megosztottsága egyértelmü: a vad típusú sejtek képesek a környezetükben található többi fajtárs jelére reagálni, illetve a jel hatására elóállított közjavak a populáció összes tagjának az előnyére szolgálnak. Ezen felül, a sejtek ugyanazt a táplálékot fogyasztják a médiumból.

Két baktériumfaj együttélése esetén azonban különböző kommunikációs (másik által termelt jel érzékelése), kooperációs (egymás közjavainak felhasználása), valamint metabolikus (ugyanazt a táplálékot fogyasztják-e, vagy sem) kölcsönhatási sémákat állíthatunk fel. Például, a jelmolekulák szempontjából két szélső eset létezik:

a) a két faj egyáltalán nem képes reagálni egymás jelmolekulájára

b) a két faj vagy ugyanazt a jelmolekulát termeli, vagy a receptor fehérjék képesek mindkét faj által termelt jelmolekulával kölcsönhatásba lépni (promiszkuitás).

Ahhoz, hogy megvizsgálhassuk a két szélső eset közötti átmenetet, ún. megosztási koefficienseket definiáltunk, melyekkel tetszőleges mértékben definiálhatjuk, hogy az ágensek milyen érzékenységgel reagáljanak a különböző diffúzibilis anyagokra. Rendre „,a”-val és „,b”vel jelöltük adott faj érzékenységét a másik faj által termelt jelre és faktorra, míg „„”-vel a másik faj táplálékából történő fogyasztás mértékét jelöltük. Az a, b és c koefficiens 0 és 1.0 közötti értéket vehet fel. Például, ha az egyik faj ('Species1', Sp1) csak a saját maga által termelt jelre képes reagálni, a másik faj ('Species2', Sp2) jelére viszont érzéketlen, akkor a szimuláció során a következő egyenletet használtuk:

$$
\mathrm{S}_{\mathrm{Sp} 1}=1.0 * \mathrm{~S}_{1}+0 * \mathrm{~S}_{2}
$$


ahol $S_{S p 1}$ az első faj összesített jelérzékenységét jelöli, míg $S_{1}$ és $S_{2}$ rendre az első és második faj jelére vonatkozó érzékenység. Ha az egyik faj (Sp1) a saját- és a másik faj táplálékából is egyenlő arányban képes fogyasztani, akkor azt a következő módon írhatjuk fel:

$$
\mathrm{N}_{\mathrm{Sp} 1}=0.5 * \mathrm{~N}_{1}+0.5 * \mathrm{~N}_{2}
$$

ahol $N_{S p 1}$ az első faj teljes táplálékfogyasztását jelöli, míg $N_{l}$ és $N_{2}$ rendre az első és második faj által fogyasztott táplálék.

Munkánk során kétféle kompetíciós esetet vizsgáltunk, nevezetesen a szimmetrikus megosztást és a kizsákmányolást (vagy aszimmetrikus megosztást). Ezeket az eseteket fel lehet írni az imént bemutatott változók megfelelő használatával (3. táblázat). Aszimmetrikus megosztás esetén a kizsákmányolt faj nem képes érzékelni a kizsákmányoló faj által termelt anyagokat, illetve felhasználni annak táplálékát, ezért a kizsákmányolt faj mindhárom megosztási koefficiense 0 az összes szimulációban.

3. táblázat: A versengő fajok megosztási koefficiens értékei szimmetrikus megosztás és kizsákmányolás esetén.

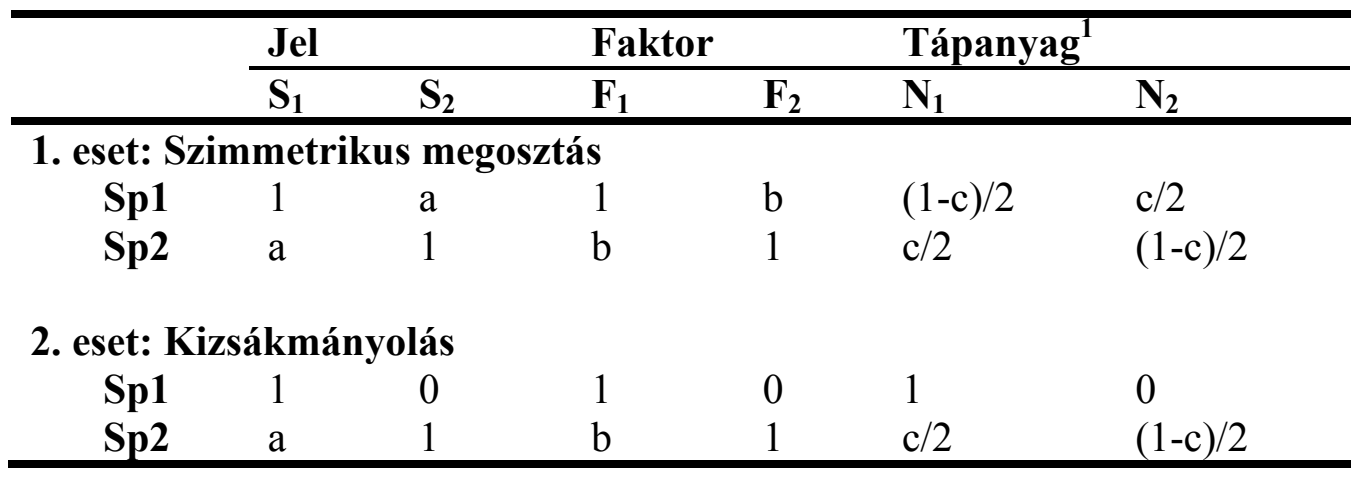

${ }^{1}$ Megjegyzés: az 1/2-es szorzóra azért van szükség a tápanyag esetében, mert az ágensek tápanyagfelvétele korlátozott minden ciklusban, vagyis minden esetben teljesülnie kell a következö feltételnek: $N_{1}+N_{2}=1$. Erre a korlátozásra a jel és a faktor esetében nincs szükség, mivel ott csak az érzékenység változik.

A fenti kompetíciós eseteket a következő módon szimuláltuk: a versengő fajokból 1000-1000 darab ágenst helyeztük el véletlenszerűen a szimulációs térben, meghatározott megosztási paraméterekkel. A szimulációk maximum 40.000 lépésig futottak, ami az általunk választott metabolikus és osztódási paraméterek tekintetében kb. 500 generációt jelentett. $\mathrm{Az}$ a, b és c értékeket 0 és 1.0 között növeltük, 0.1 lépésközzel, így feltérképezve a paraméter teret. 


\section{A szimulációs eredmények feldolgozása és kiértékelése}

A program a szimuláció főbb paramétereit egy .csv formátumú szöveges fájlból olvassa be és a futás végén szintén táblázatos formában menti el a szimuláció főbb adatait. A program kétféle üzemmódban futtatható: normál üzemmódban meghatározott lépésenként elmentjük a populáció főbb paramétereit (pl. egyes fajok egyedszáma, adott állapotú sejtek száma, a kolónia átlagsebessége, stb.) egy szöveges fájlba. Így lehetőségünk van részletesen elemezni, milyen változások következnek be a populációban az idö függvényében. A statisztikus üzemmódot viszont arra fejlesztettük ki, hogy tömegesen futtathassunk szimulációkat, melyeknek csak a végeredményét mentjük el. Az így kapott eredményeket táblázatba foglaltuk, melyen további statisztikai vizsgálatokat folytathatunk. Ennek céljából igyekeztünk olyan paramétereket definiálni, melyek egyértelműen tükrözik a populáció végállapotát. Ezek közül a relatív fitneszt és a szegregációs indexet emelném ki [114].

\section{a. Relatív fitnesz: a versengő populációk numerikus karakterizálása}

$\mathrm{Az}$ ágens populációkat kezdetben az stacioner állapot során kialakult átlagos méretükkel jellemeztük. Azonban a több faj kompetíciója, továbbá a megosztási koefficiensek bevezetésé miatt definiálnunk kellett egy változót, melynek kiszámításával jellemezni lehet az stacioner populációk méretét a referencia populációhoz képest. Az ágenspopulációk rátermettségét a Mitri és mtsai. által használt fitnesszel írjuk le, melyet a populáció kezdeti is végső mérete alapján határozunk meg [115]. Az adott faj fitneszét következő képlettel írjuk le:

$$
\mathrm{F}=\frac{1}{\Delta \mathrm{t}} \log _{2} \frac{\mathrm{N}_{\mathrm{end}}}{\mathrm{N}_{\mathrm{start}}}
$$

ahol $F$ a fitnesz érték, $\Delta t$ az eltelt időt, míg $N_{\text {start }}$ és $N_{\text {end }}$ a populáció méretét jelöli a szimuláció kezdetén és végén. A fitnesz egy mértékegység nélküli mennyiség, melyet, ha elosztunk egy referencia faj fitneszével, akkor megkapjuk a vonatkozó faj relativ fitneszét:

$$
\mathrm{F}_{\mathrm{rel}}=\frac{\log _{2}\left(\mathrm{~N}_{\mathrm{end}} / \mathrm{N}_{\text {start }}\right)}{\log _{2}\left(\mathrm{~N}_{\text {end,ref }} / \mathrm{N}_{\text {start,ref }}\right)}
$$

melyben $F_{r e l}$ a relatív fitnesz, $N_{\text {start,ref és }} N_{\text {end,ref }}$ pedig a referencia populáció kiindulási és végső méretét jelöli. Szimulációink során a referencia populációnak minden esetben az adott fajnak ugyanabban a környezetben, konkurens faj nélkül növekvő populációját vettük. Vagyis ebben az esetben az $F_{r e l}$ azt a fitnesz változást fejezi ki, mely a kolónia formálásból adódik. A gyakorlatban, ha $F_{r e l}$ nagyobb, mint 1.00 , akkor az adott faj egyedszáma nagyobb lesz a 
kialakult közösségben, mintha a másik faj nélkül növekedne a szimulációs térben. Vagyis számára előnyös közösséget kialakítania konkurens fajjal. Ha azonban $F_{r e l}$ értéke 1.00-nál kisebb, akkor kevesebb ágens lesz adott fajból az stacioner konzorciumban, vagyis számára hátrányos közösséget alkotni a másik fajjal.

\section{b. Szegregációs index: a rajzó populációk térbeli szétválásának jellemzése}

Modellünkben a rajzó kolóniák egyenletes sebességgel haladnak a szimulációs térben a táplálékban gazdag régió irányába. A szimuláció során nyomon követhetjük a populációk túlélését, vagy összeomlását az ágensek létszámának ciklusonkénti ellenörzésével. A véletlenszerüen kevert populációkból (cellánként 5-5 egyed fajonként) kiinduló szimulációk során a kolóniák térbeli elrendeződése is változik az idő előrehaladtával, mely többféle kimenetet mutathat: bizonyos kolóniák idővel szétválnak, míg mások kevert állapotban maradnak legalább 500 generáción keresztül (20. ábra).
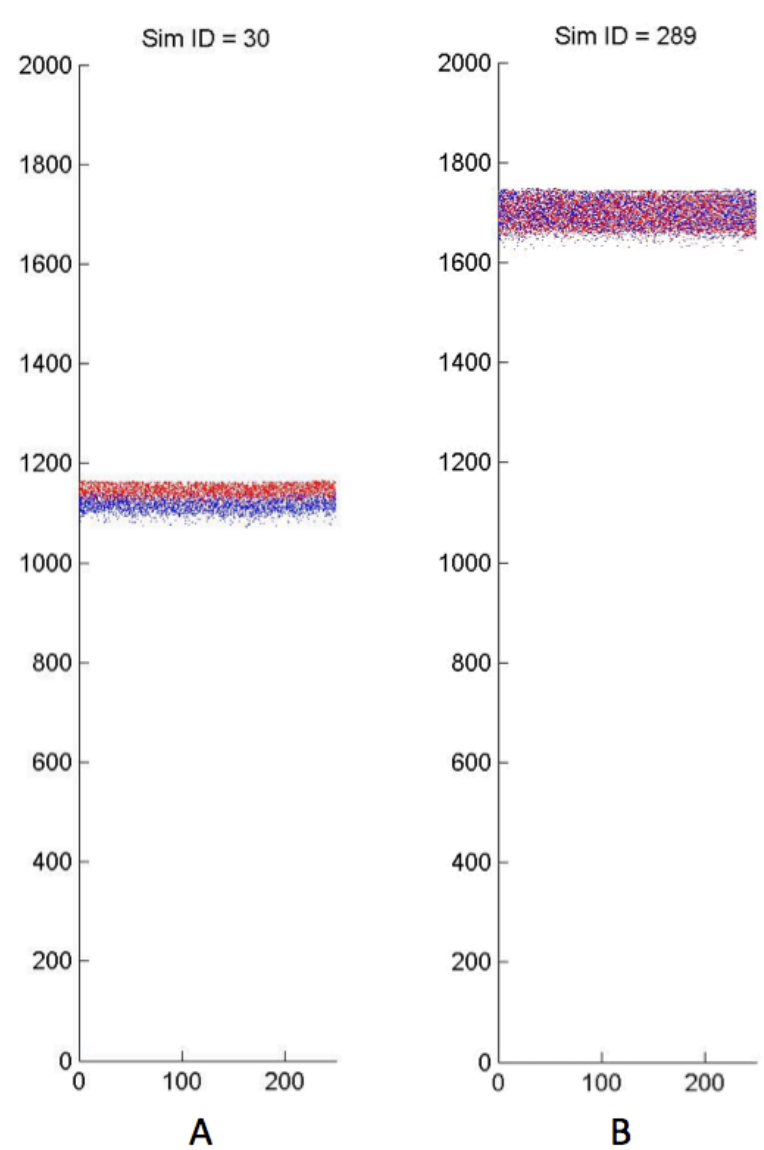

20. ábra: 2 faj együttes szimulációja során különböző jel- és faktormegosztás esetében szegregáló populációk (A), vagy kevert populációk (B) jönnek létre (részletesen lásd 4.3.1. fejezet). Sim ID: a szimuláció azonosítója 
Mitri és mtsai [115] a jelenséget egy intuitív szegregációs index segítségével írták le Nadell és mtsai munkája alapján [116]. Módszerük az adott ágens legközelebbi szomszédainak számolására épül. Ezt a számítást a populáció minden tagjára el kell végezni, minden egyes ciklusban, így az algoritmus futási ideje $O\left(n^{2}\right)$ komplexitású, ahol $n$ az ágensek számát jelöli. Mivel meglehetősen nagy egyedszámú kolóniákkal dolgoztunk - melyekben akár 50000 ágens is lehet a stacioner populációban -, keresnünk kellett egy kevésbé számolásigényes módszert, amivel jellemezni lehet a populációk szétválását.

Ehhez kihasználtuk a modellünknek azt a tulajdonságát, hogy a szimulációs tér cellákra van felosztva, így könnyedén megszámolhatjuk, hogy egy adott cellában hány db ágens helyezkedik el fajonként. Például, 2 faj esetében kiszámolhatjuk az i-edik cellasorhoz tartozó $n_{1}(i)$ és $n_{2}(i)$ értékeket, mely az adott faj egyedszámát jelenti az i-edik sorban (lásd 20. ábra). Ha az i-edik sorban található összes ágens számát $N(i)$-vel jelöljük, akkor az $n_{s}(i) / N(i)$ hányadossal megadhatjuk az adott $\mathrm{S}$ faj arányát az adott sorban. Ha a populációk szegregálnak, akkor ez az érték 1 lesz az egyik fajra nézve, míg a másikra 0 . Teljesen kevert populációk esetében mindkét fajra nézve 1/2 körüli értéket fogunk kapni minden sorra.

Az szegregációs index $(S)$ számításához a soronkénti maximális egyedszám értékek átlagát vesszük:

$$
\mathrm{S}=\frac{\sum_{i} \max \left(n_{i}\right)}{\mathrm{N}_{\text {population }}}
$$

ahol $\max \left(n_{i}\right)$ a domináns faj sejtszáma az i-edik sorban, míg $N_{\text {population }}$ az összes egyed számát jelöli. Két faj esetében $S$ értéke $1 / 2$ és 1 közé esik, míg $n$ db faj esetében $1 / n$ és 1 közötti értéket kapunk. Az egyszerübb összehasonlítás érdekében $\mathrm{S}$ értékét normalizáltuk, mely által vizsgált fajok számától független értékeket kapunk. A normalizált szegregációs index $\left(S_{N}\right)$ számítása a következő:

$$
\mathrm{S}_{\mathrm{N}}=\frac{\mathrm{S}-1 / \mathrm{N}_{\text {species }}}{1-1 / \mathrm{N}_{\text {species }}}
$$

ahol $S$ az előző egyenletben használt szegregációs index, míg $N_{\text {species }}$ a szimulációban résztvevő fajok számát jelöli. Teljes szétválás esetében $S_{N}$ értéke 1-hez, míg kevert populációk esetében 0-hoz közelít. A normalizált szegregációs index számításához szükséges idő egyenesen arányos az ágensek számával $(n)$, vagyis futásideje $O(n)$ komplexitású. 


\section{Az eredmények vizualizálása a paramétertér függvényében}

A paramétertér feltérképezéséhez nagyszámú különálló szimulációt futtattunk, melyek átfogó értelmezéséhez hőtérképeket készítettünk. Ezeken az ábrákon a szignál és faktor megosztás, valamint a táplálék megosztás függvényében ábrázoltuk a szimuláció különböző paramétereit. Az 21. A ábrán látható hőtérképeken pl. a relatív fitnesz-t ábrázoltuk oly módon, hogy különböző $F_{r e l}$ értékekhez különböző árnyalatot rendeltünk. A jel megosztását az xtengelyen, míg a faktor megosztását az y-tengelyen ábrázoltam. A ábra bal felső fekete régiója azt jelenti ebben a példában, hogy abban a térben a szimulációk 0 körüli szegregációs indexnél érték el a szimuláció végét, vagyis a populációk stabil, kevert közösséget formáltak (lásd 4.3. fejezet).

Hasonló módon ábrákat készíthetünk a szimulációk egyéb jellemző paramétereiből, mint a szegregációs index, de az is vizualizálható és kvalitatív módon értékelhető, hogy egy adott szimuláció kihalással, vagy a két faj stabil együttélésével záródott-e.

Az eredmények globális áttekintéséhez a fenti hőtérképeket egyszerre ábrázoltuk egy 3D ábrán, melynek z-tengelye a táplálék megosztást jelenti (21. B ábra). Így a különböző táplálékmegosztáshoz tartozó hőtérképeket egymás felett ábrázolhattuk egyetlen ábrán.

A

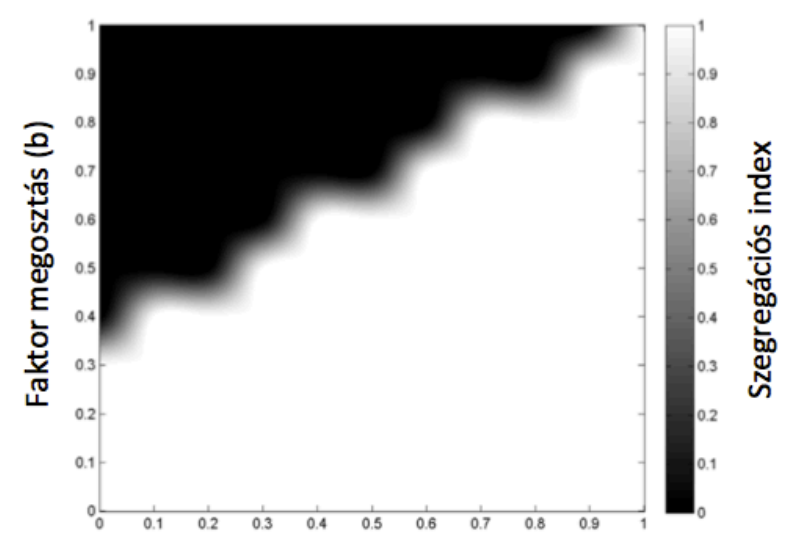

Jel megosztás (a)
B

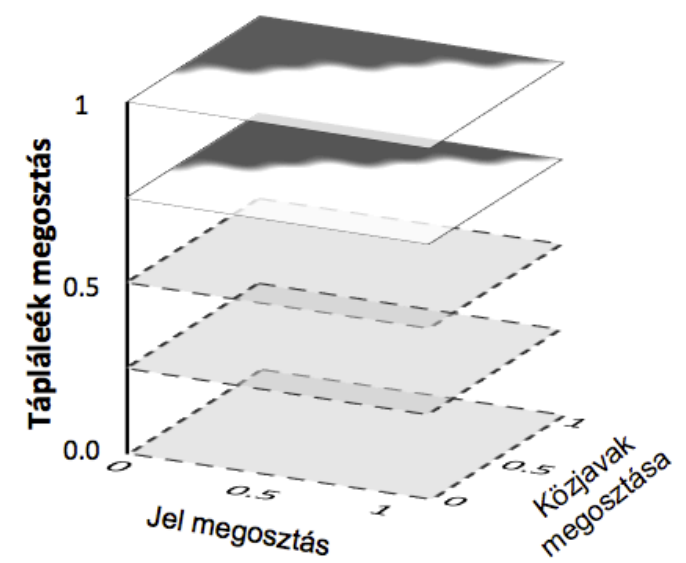

21. ábra: A) A szegregációs index hőtérképes ábrázolása jel és faktor megosztásának függvényében. A fekete terület azt a paramétertartományt reprezentálja, melyben a a két versengó populáció stabil, kevert közösséget formál, vagyis a szegregációs index értéke 0.5 alatti. Az eredmények a jel és faktor, valamint a tápanyag aszimmetrikus megosztásának szimulációjából származnak, ahol a c-vel jelölt tápanyag megosztási koefficiens 0.6. B) A különböző tápanyag megosztási értékek alapján készült hőtérképeket másik típusú 3D ábrán is szemléltethetjük, melynek z tengelyén a különböző tápanyag megosztási hőtérképeket ábrázoltuk egymás felett. 


\section{Eredmények és diszkusszió}

Eredményeinket három témakörben fogom bemutatni. A 4.1. fejezetben ismertetem azokat az in vitro és in silico kísérleteket, melyekkel igazoltuk, hogy a rendszerünk alkalmas a P. aeruginosa vad típusú és QS deléciós mutáns törzsek rajzásának modellezésére. A 4.2. fejezetben kevert populációk rajzási mintázatait vizsgáltuk meg laboratóriumi kísérletekkel, ill. szimulációkkal és választ kerestünk az eredmények során tapasztalt lokális összeomlás jelenségére. Az utolsó, 4.3. fejezetben egy in silico tanulmányt ismertetek, melyben azonos térben versengő fajok kooperációját és kommunikációját vizsgáltunk meg a jel, faktor és táplálék megosztásának függvényében.

\subsection{P. aeruginosa rajzásának in vitro és in silico vizsgálata}

\subsubsection{A rajzás in vitro vizsgálata exogén jel hiányában és jelenlétében}

A $P$. aeruginosa QS által szabályzott rajzása molekuláris szinten jól leírt jelenség. A szabályzó folyamatok további pontosabb megértése érdekében laboratóriumi körülmények között is megvizsgáltuk meg a jelmolekulák rajzásra kifejtett hatását. A kísérletek során vad típusú (WT) P. aeruginosa (PUPa3 törzs) és QS deléciós mutáns törzsekkel (SN és SB) dolgozunk (lásd Módszerek).
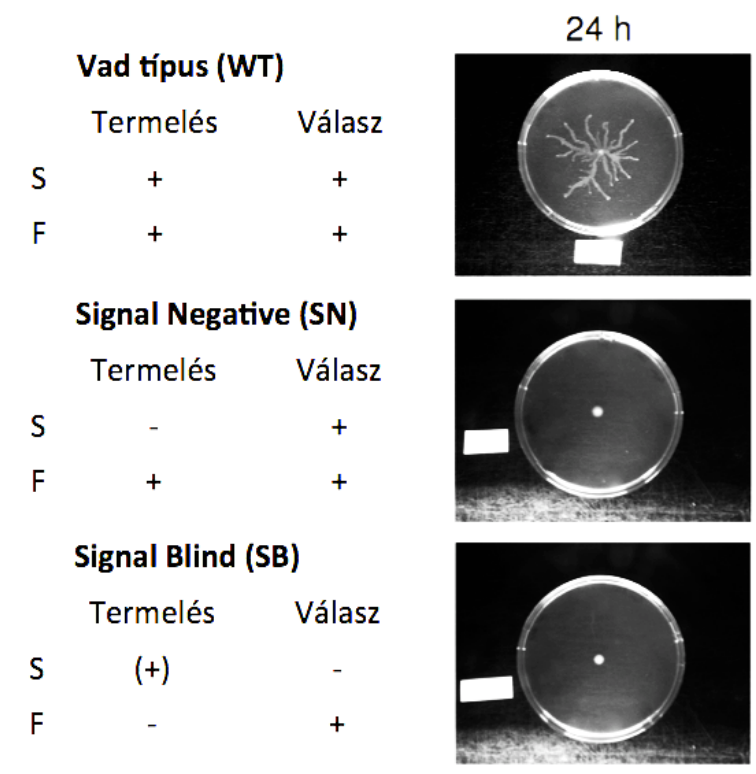

22. ábra: P. aeruginosa rajzása agar médiumon. A sejtek fenotípusait az ábra bal oldalán jelöltem. A Petricsészés ábrákon láthatjuk, hogy csak a WT sejtek voltak képesek rajzó kolóniát képezniAz SB esetében a zárójel azt jelenti, hogy a sejtek rendelkeznek alapszintü jeltermeléssel, amely rajzás esetében nem fokozódik, mivel a mutáció miatt hiányzik a QS szabályzórendszerükből az autoindukciós kör. 
A különböző törzsek rajzását az 22. és 23. ábrán foglaltam össze. Külsőleg hozzáadott (exogén) jel hiányában csak a WT sejtek voltak képesek rajzó kolóniát kialakítani az inkubációs idő alatt (22. ábra).

Exogén jellel kezelt táptalajon viszont az SN mutáns is kialakított rajzó kolóniákat (23. ábra). Az SB mutánsok viszont egyik esetben sem voltak képesek rajzásra.

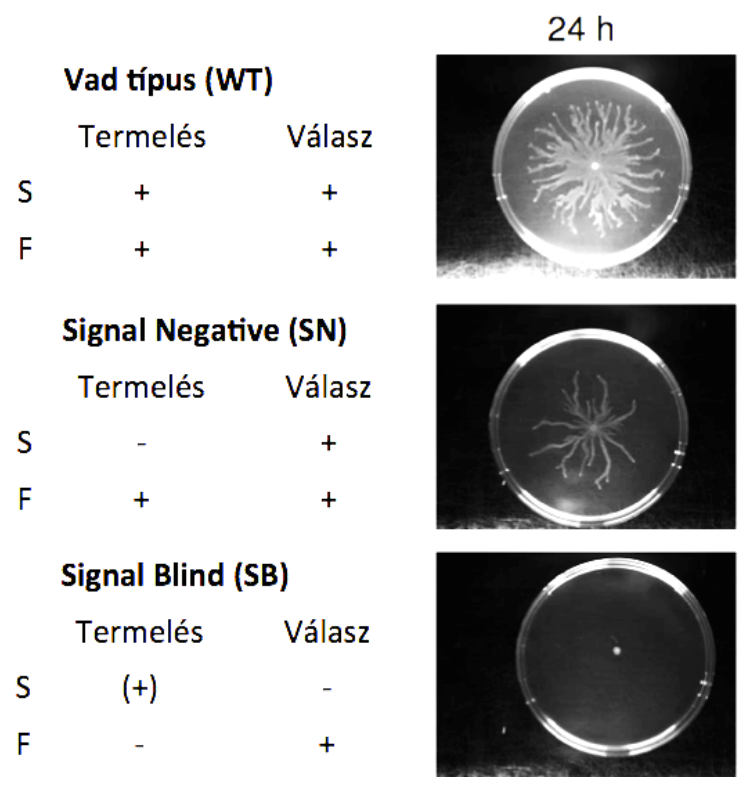

23. ábra: Külső jel hatására a WT mellett az SN mutánsok is rajzásnak indultak. A laboratóriumi kísérletek esetében az agar médiumhoz AHL jelmolekulát adtunk, $2 \mu \mathrm{M}$ koncentrációban. A WT sejtek hasonló mintázatot produkáltak, mint külső jel hiányában (lásd 22. ábra).

\subsubsection{A rajzás in silico vizsgálata exogén jel hiányában és jelenlétében}

A laboratóriumi kísérletek mellett elvégeztük az előző fejezetben bemutatott kísérletek in silico megfelelöit. Külső jel hiányában csak a WT ágensek voltak képesek rajzó kolóniát kialakítani (24. A ábra). A táptalajhoz adott jelmolekulákat a szimulációs rendszerben úgy modelleztük, hogy a teljes szimulációs térben küszöb feletti koncentrációra állítottuk $\mathrm{S}$ értékét. Az exogén jelmolekula jelenlétében a WT mellett az SN mutánsok is képesek voltak rajzásra (24. B ábra). Viszont akárcsak a laboratóriumi kísérletek esetében, az SB mutánsok a szimulációkban sem voltak képesek rajzó kolóniát kialakítani, még S jelenlétében sem. 
A. Szimulációk exogén jel hiányában

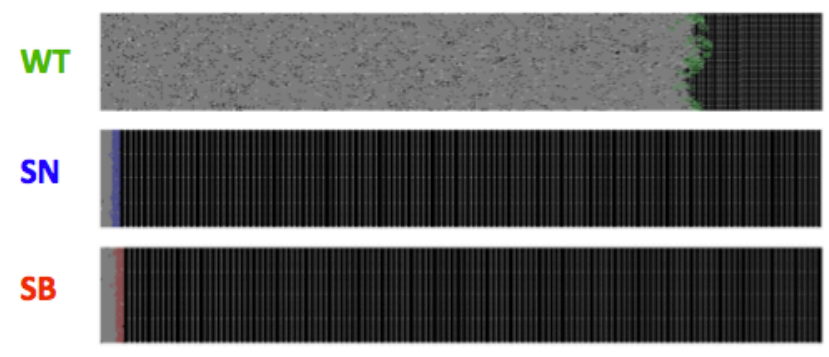

B. Szimulációk exogén jellel

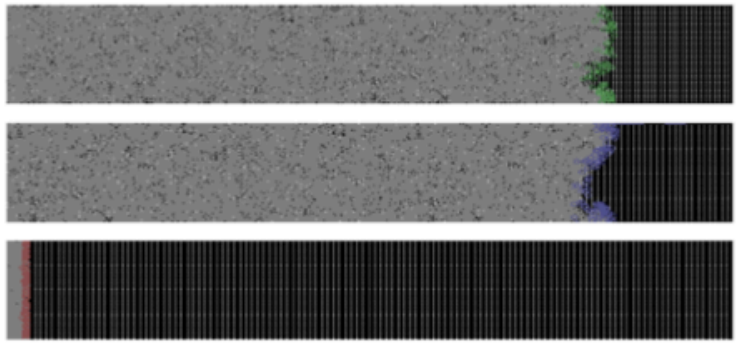

24. ábra: A) Exogén jel hiányában a szimulációk során csak a WT ágensek (zöld színnel jelölve) alkottak stabil rajzó populációt. B) Exogén jel (S) küszöb feletti koncentrációja mellett az SN ágensek is rajzásnak indultak. Viszont az SB mutánsok egyik esetben sem voltak képesek rajzó kolóniát létrehozni, ahogy azt a laboratóriumi kísérleteknél is tapasztaltuk.

\subsubsection{Sürüség függő aktiváció ágens populációkban}

A QS definíció szerint sejtsürüség függő választ jelent a populáció szintjén (lásd 1.2.1. fejezet), melyet részletesen vizsgálhattunk az ágens modellünk segítségével. A szimuláció indításakor planktonikus állapotú ágensek voltak a szimulációs térben (cellánként $1 \mathrm{db}$ ágens), melyek először aktív állapotba kerültek a jel küszöbkoncentrációjának elérésekor. Az állapotváltozás mellett a populáció mérete is növekedésnek indult, mivel az ágensek a táplálkozás révén folyamatosan energiát halmoztak fel és osztódásnak indultak. Rövid időn belül szinte az egész kolónia rajzó állapotba került, mivel a faktor koncentrációja is gyorsan elérte a küszöbszintet. A jelenség időbeli lefolyását a 25. ábrán foglaltam össze: a felső diagramon a populációban található ágensek állapotainak eloszlását ábrázoltam az idő függvényében. Az alsó diagramon láthatjuk, hogy a cellánkénti sejtszám, vagyis a sejtsürüség növekedésével összhangban váltottak állapotot az ágensek.

A modellel megvizsgálhattuk tehát a QS korai szakaszában lezajló állapotváltozásokat. 


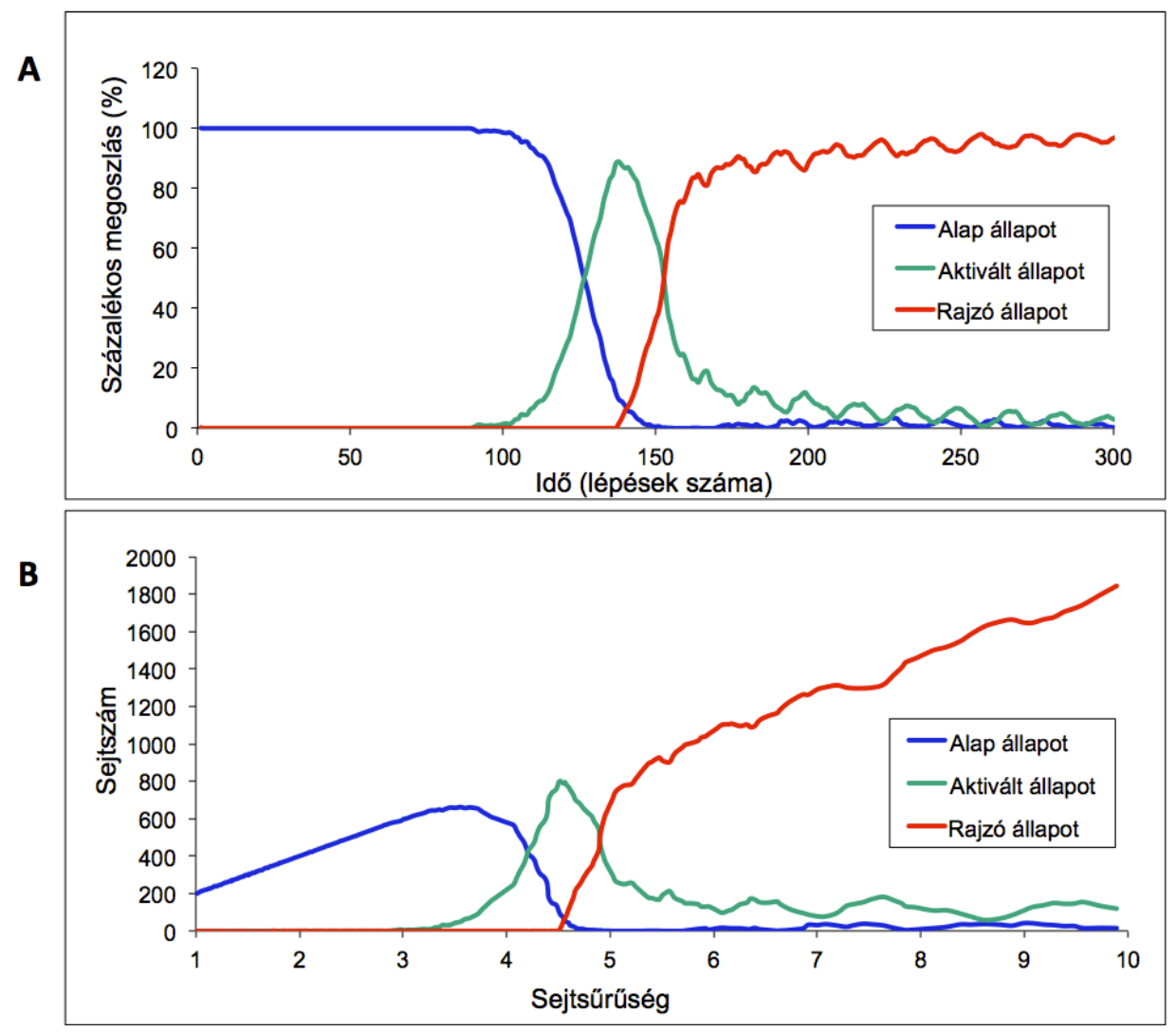

25. ábra: A) A planktonikus (kék), a faktort termelö, de még nem rajzó (zöld), ill. a rajzó (piros) ágensek százalékos megoszlása a populációban az idő függvényében. Kis idő elteltével szinte az egész populáció rajzó állapotba került. B) Az ágensek állapota a sürüség függvényében. Megfigyelhető, hogy egy bizonyos sejtsürüség felett a populáció összetétele jelentősen megváltozott, mivel a populáció rajzó állapotba került. Vagyis a modell jól szimulálja a sűrüségfüggő állapotváltást. A felső ábrán látható oszcillációk a diszkrét modellezés melléktermékei.

\subsubsection{Kémiai jelek követésének modellezése}

A fentebb bemutatott szimulációk esetében a rajzó baktériumok a tápanyagban gazdag területek irányába haladtak. A rajzáshoz a táplálékon kívül jelmolekulákra is szükség van, így feltételezhető, hogy a sejtek képesek egy olyan nyomvonalat követni, mely hozzáadott jelmolekulát tartalmaz. A 26. ábra egy ilyen szimulációt illusztrál, mely során kijelöltünk a szimulációs tér felszínén egy olyan mesterséges nyomvonalat, melynek területén a jelmolekula koncentrációja küszöb feletti. A szimuláció során SN mutánst használtunk, mely nem képes jelet termelni, de képes reagálni annak jelenlétére. Eredményeink alapján a rajzó kolónia a random mozgás ellenére követte a mesterségesen kialakított ösvényt. Ezzel a szimulációval bemutattuk, hogy ez az egyszerü gén-aktivációs modell nem csak a sejtsűrüségre adott válaszreakciót képes szimulálni, hanem a baktériumok jelkövetését is, mely megfigyelhető pl. gazda/szimbionta, ill. növény/patogén interakcióknál. 


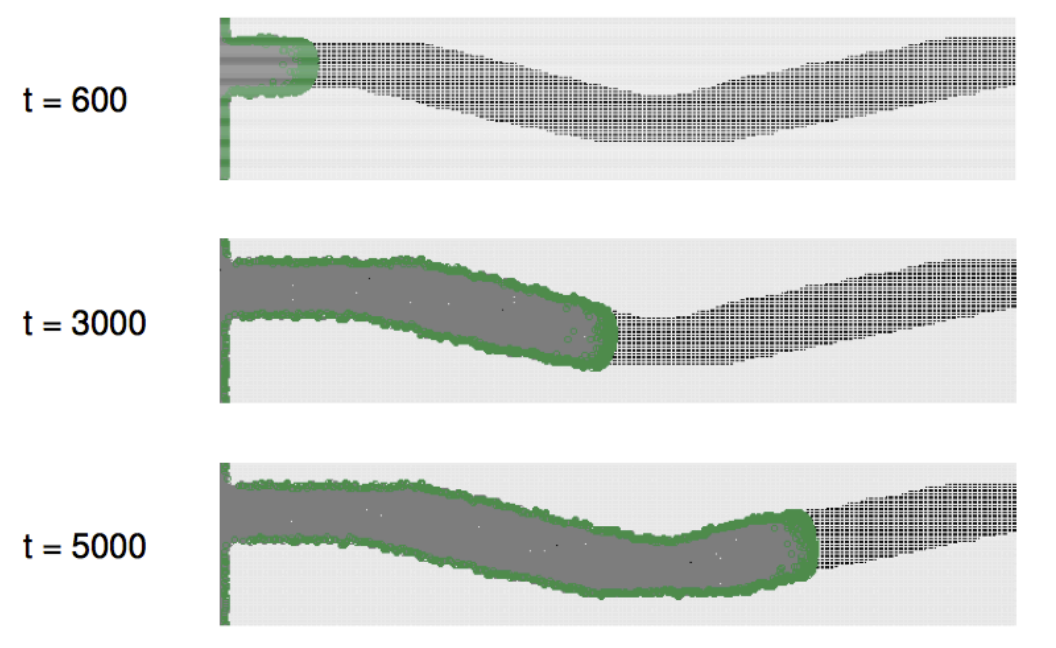

26. ábra: A szimulációhoz egy szabálytalan alakú, mesterséges nyomvonalat készítettünk, mely területén a jelmolekula koncentrációja küszöb feletti, továbbá ezen a területen a jel nem diffundál és nem bomlik el. A szimuláció során SN típusú ágenseket használtunk, melyek nem képesek jel termelésére, de képesek arra válaszreakciót mutatni. A rajzás csak a kijelölt útvonalon történik. Az egyes ábrák különböző időpillanatokban készültek a szimuláció során. 


\subsection{A baktériumpopuláció lokális összeomlása csaló mutánsok megjelenése esetén}

A mikrobiális közösségek jelentős előnyre tesznek szert a kooperáció, vagyis a termelt jelmolekulák és közjavak megosztása révén a nem kooperáló kolóniákhoz képest. Másrészről a sejtek között állandó kompetíció áll fenn a táplálékért és a térért, ami alapján feltételezhetjük, hogy a két ellentétes irányú folyamat között valamiféle egyensúly áll fenn. A nem kooperáló, ún. csaló mutánsok rendkívül gyorsan képesek elterjedni a populációban, aminek drasztikus következményei lehetnek a teljes közösségre nézve. A következőben ismertetni fogok egy hipotézist a lokális kommunikáció lehetséges hatásáról, valamint egy kísérleti rendszert, melyben a különböző QS mutánsok közösségre kifejtett hatását tanulmányoztuk és melyet a modellünk segítségévek in silico is szimuláltunk.

\subsubsection{Lokális és globális kommunikáció mikrobiális közösségekben}

A baktériumok több fajból álló közösségeiben a résztvevő fajok együttesen használják fel a környezeti erőforrásokat és viszonylag stabil, hosszú időn keresztül együttélő konzorciumokat alkothatnak. Bizonyos feltételek teljesülése esetén a kolóniák jól tolerálják a csaló mutánsok megjelenését, melyek sok esetben a teljes közösség pusztulását okozhatják. Egy lehetséges védelmi mechanizmusról állítottunk fel hipotézist, melyet ebben a fejezetben ismertetek röviden.

A közösségek stabilitásának fogalmán egyrészt érthetünk funkcionális stabilitást, mely esetében minden olyan jelleg jelen van egy közösségben, ami a teljes közösség túléléshez szükséges. Ezen felül beszélhetünk a stabilitás metagenomikai szintjéről is, vagyis a közösség megfelelö génkészlettel rendelkezik ahhoz, hogy közösség hosszútávon müködőképes legyen.

Egy mikrobiális közösséget elképzelhetünk olyan részlegesen átfedő al-struktúrák összességeként, melyek lokálisan kommunikálnak egymással diffúzibilis jelmolekulák segítségével (27. ábra). Ezek az al-strukturák biztosíthatják a közösség stabilitását, ugyanis ha megjelenik egy csaló mutáns törzs, vagy egy nem kooperáló faj kerül a rendszerbe, akkor az al-struktúra szétesése biztosítja a kolónia további részeinek zavartalan müködését. Ezzel szemben, globális kommunikáció valósul meg pl. rázatott folyadékkultúrákban, melyekben a sejtek által termelt jelmolekula az egész közösségre hatással van (27. ábra). Ezek a rendszerek sérülékenyebbek, mivel nincs lehetőség a csaló mutánsok eliminálására, melyek megjelenése esetén az egész közösség elpusztulhat [117-118]. 


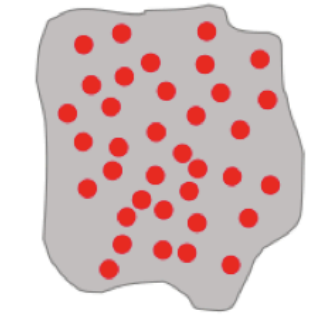

Globálisan kommunikáló közösség

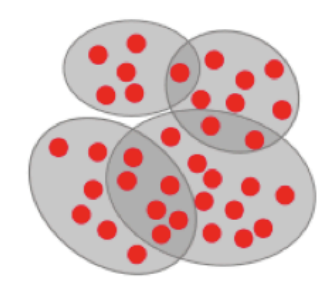

Lokálisan kommunikáló közösség

27. ábra: A) A globális kommunikáció sémája, mely során a populáció összes tagja kölcsönhatásban van egymással. pl. rázatott folyadékkultúrák esetében beszélhetünk globális kommunikációról. B) A lokális kommunikáció során a sejtek csak a közelebbi szomszédjaikkal vannak interakcióban. Szilárd felszínen, ill. strukturált környezetben, biofilmekben alakulhatnak ki lokálisan kommunikáló egységek, ún. al-struktúrák, melyek átfedésben vannak egymással.

Az általunk felállított hipotézis alapján a rajzó kolónia képes lokalizálni a nem kooperáló mutánsokat. Ez alapján feltételezhetjük, hogy a lokális közösségek kialakulása hozzájárulhat a stabil közösségek kialakulásához, speciális védelmi mechanizmusok (pl. antibiotikumok termelése, extracelluláris mátrix, stb.) nélkül is. Ennek az egyszerü védelmi rendszernek a hatására a QS mutánsok nem tudják elözönleni a populációt, melynek végzetes következményei lehetnek. A hipotézisben nem feltételezzük, hogy a mikrobiális kommunikáció alapvetően lokális, inkább a globális- és lokális kommunikáció egyensúlyaként tekinthetünk rá. Ugyanis egy biofilmben, vagy egy rajzó kolóniában a távolabbi sejtek kisebb valószínüséggel kerülnek interakcióba egy adott sejttel, mint a közvetlen környezetében lévő szomszédos sejtekkel. Ezek az al-struktúrák átfedésben vannak egymással, továbbá, ha az alstukrturák sugarának mérete növekszik, vagyis a kolónia egyre távolabbi sejtjeit is képesek befolyásolni, akkor a kommunikáció egyre inkább globálisnak tekinthető.

\subsubsection{A kísérleti rendszer bemutatása}

Az in vitro és in silico kísérletek során azokat a törzseket használtuk, melyeket a 3.1. fejezet 2. táblázatában ismertettem. A laboratóriumi kísérletek eredményei alapján elmondható, hogy az $\Delta r h l$ mutánsok egyáltalán nem képesek a rajzásra, a $\Delta l a s$ mutánsok viszont igen, bár kisebb hatékonysággal, mint a vad típusú sejtek.

A LasI/R rendszer tehát kevésbé fontos szerepet tölt be a rajzó mozgás során, mint az RhlI/R rendszer. Ez utóbbi felelős ugyanis a rhamnolipid termelésért, mely a rajzás egyik szükséges feltétele. Mindkét rendszer kiütésével azonban végérvényesen elvesztik a sejtek a rajzási képességüket [112]. A kísérletek során a keletkezett kolóniákat három csoportba 
soroltuk be a morfológiájuk alapján: rajzó, nem rajzó és összeomlott kolóniák (28. ábra, jobb felső sarok). A szintázban hiányt szenvedő mutánsok ("I mutánsok") nem képesek az AHL termelésre ("információs csalók"), viszont külső jelmolekulák esetében expresszálódnak a faktorok termeléséért felelős gének. A receptort nem expresszáló mutánsok ("R mutánsok") viszont bár képesek jelmolekulákat termelni, nem képesek faktor molekulák előállítására, ami jelentős metabolikus előnyhöz juttatja őket a faktorokat termelő sejtekhez képest ("közjó csalók").

\subsubsection{Vad típusú és különböző QS deléciós mutánsok együtt-rajzása}

A rajzási kooperációt a különböző törzsek 1:1 arányú keverékéből alkotott mesterséges közösségek közös táptalajra történő oltásával tanulmányoztuk (28. ábra). Az együtt-rajzás tényét egyértelmüen lehetett detektálni, mivel a különböző mutánsok különböző antibiotikum markereket hordoztak a genomjukban, így csak az egyik törzs önállóan nem lett volna képes rajzásra az antibiotikumokat tartalmazó táptalajon.

Megfigyeltük, hogy a kevert kolóniák eltérő kolóniamintázatokat mutattak, mint a monokultúrás tenyészetek: a szintáz gének deléciója esetén (SN mutánsok, $\Delta l a s I, \Delta r h l I)$ a kolóniák nem képesek önálló rajzára, viszont a vad típusú sejtekkel együtt képesek arra, bár lassabb sebességgel, mint ha a vad típus egyedül lenne. Az SB mutánsok viszont a vad típussal együtt sem képesek stabil rajzó kolóniát létrehozni. A kolónia ugyanis idővel összeomlik és a növekedés megáll.

A $\Delta r h l I$ mutánsok szintén csak intakt RhlI/R rendszerrel rendelkező partnerrel képesek kevert rajzó kolóniát kialakítani, mivel a jelmolekulát termelő sejtek biztosítják a teljes kolónia rajzásához szükséges jelmolekula mennyiséget. Másrészről, a $\Delta r h l I$ és $\Delta r h l R$ mutánsok nem képesek önálló rajzó kolóniát kialakítani, mivel egyik résztvevőnek sincs intakt RhlI/R rendszere, ez által hiányzik az autoinduktív kör, mely a jelmolekula termelést fokozza. 


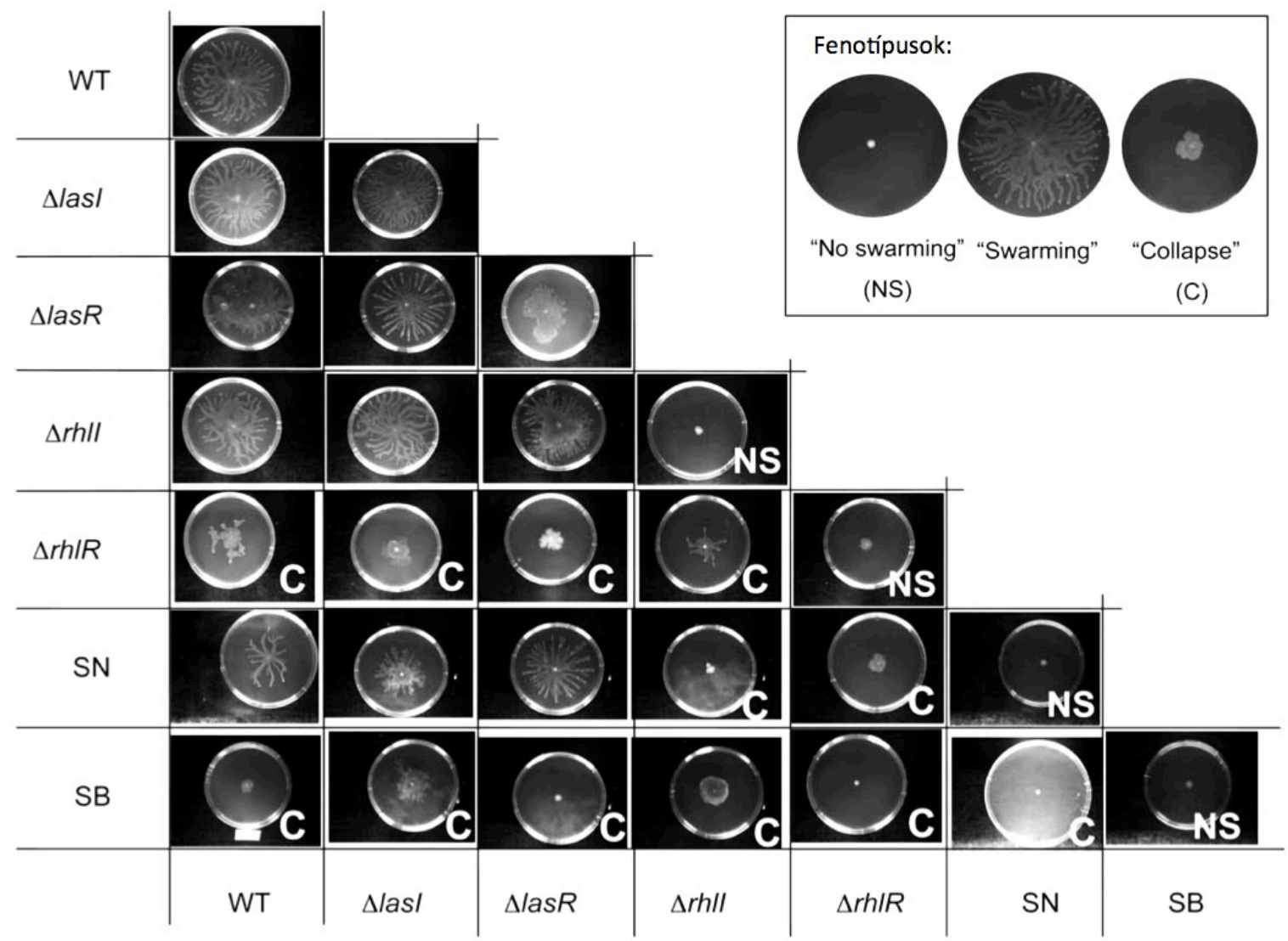

28. ábra: P. aeruginosa PUPa3 sejtek rajzása és együtt-rajzása QS deléciós mutánsokkal. A táblázatban az összes lehetséges kombinációt ábrázoltuk. A monokultúrás kolóniák a fóátlóban láthatók. C: "collapse", összeomlott kolónia; NS: "no-swarming". A $\Delta r h l R$ és az SB mutánsok a kevert kultúták esetén összeomlást okoznak.

\subsubsection{Kolóniadinamika in vitro kísérleteknél: rajzás és összeomlás}

Megvizsgáltuk, hogyan változik a populáció összetétele az idő függvényében, ezért a rajzás során rendszeres időközönként mintát vettünk a populációból és megvizsgáltuk annak összetételét. A kísérletek során megfigyeltük, hogy minden esetben mindkét törzs jelen volt a dendritekben, viszont különböző arányokban: a rajzás végére a deléciós mutánsok minden esetben nagyobb arányba voltak jelen a populációban, mint a vad típusú sejtek (29. ábra). A jelenség mögött valószínüleg a metabolikus előny állhat, mivel a deléciós mutánsok esetében nagyszámú gén marad inaktív.

Ennek fényében az $R$ mutánsok nagyobb metabolikus előnnyel rendelkezhetnek, mint az I mutánsok, mivel sokkal nagyobb arányban vannak jelen a közösségben. Az utóbbiak képesek kialakítani rajzó kevert kolóniákat, viszont az $R$ mutánsok kör alakú telepeket képeznek, melyek növekedése limitált az azonos összetételű agar-médium ellenére. Ez 'quorum összeomlásnak' nevezzük, ugyanis a nem kooperáló mutánsok aránya egy olyan 
kritikus küszöböt ér el, ami miatt a kooperáló sejtek már nem képesek a teljes kolónia rajzásához szükséges mennyiségben a közjavakat elöállítani.
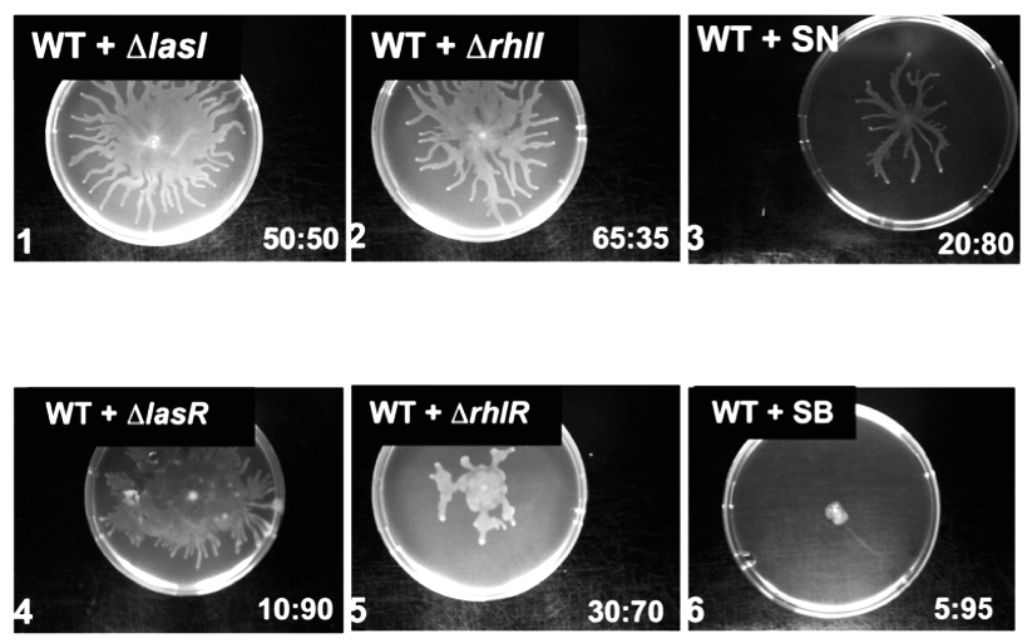

29. ábra: A P. aeuginosa PUPa3 (WT) együtt-rajzása különböző QS mutánsokkal. A WT és mutáns törzseket 1:1 arányban oltották le a rajzó táptalajok közepére. A kísérletek végére különböző WT:mutáns arányok alakultak ki, melyet a képek jobb alsó sarkában vannak feltüntetve. Az arányok a kísérlet végén a dendritek végéből/kolónia széléröl vett minták alapján elvégzett CFU számlálások alapján készültek el. WT együtt-rajzása $\Delta$ lasI (1), $\Delta$ rhlI (2) és dupla $\Delta l a s I / r h l I(\mathrm{SN}, 3)$ mutánsokkal tipikus rajzó kolóniákat eredményezett. A vad típusú $P$. aeruginosa $\Delta r h l R(5)$ mutánssal csökkent mértékü rajzást produkált, és dupla $\Delta l a s R / r h l R(\mathrm{SB}, 6)$ mutánssal gyakorlatilag nem képezet rajzó telepeket. WT $+\Delta l a s R$ kolóniák esetében viszont tapasztaltunk rajzó kolóniákat, viszont a rajzás lassabb volt, mint a WT esetében.

A jelenséget tehát két kategóriába soroltuk: a) stabil rajzás, mely során a kevert kolónia folyamatosan fenntartja rajzó állapotát, ill. b) átmeneti (tranziens) rajzás, mely esetében vagy a csaló mutáns, vagy a kooperáló partner tünik el a rajzó kolóniából. Az utóbbi esetben beszélünk quorum összeomlásról, mely által a kolónia stagnáló állapotba kerül.

Az agar-médiumos kísérletek esetében homogén kevert kultúrákat oltottunk a táptalaj közepére, de a felszínen szabadon növekvő kultúrák idővel elvesztik a homogenitásukat és csak nagyon kis területi egységeken tekinthetjük kevertnek a kolóniát. Felmerül a kérdés, hogy az összeomlás a teljes populációt érinti, vagy csak a lokális környezetükre vannak hatással a csaló sejtek. A kérdés megválaszolásához SB mutánsokat injektáltunk a rajzó WT kolónia növekvő dendritjeinek végére (30. ábra). A kezelt dendritek növekedése megállt, míg a többi, kezeletlen dendrit normális ütemben növekedett tovább. Néhány ritka esetben a rajzó kolónia sikeresen túlhaladt az SB kolónián és folytatta a növekedést. Mindkét esetben a csaló sejtek lokalizálva maradtak, vagy az összeomlás által, vagy azért, mert az SB sejtek nem csatlakoztak a rajzó WT kolóniához. Feltételezhető tehát, hogy a rajzás a lokális kommunikáción, ill. kooperáción alapul, mely által lehetőség van a QS csalók izolálására. Ez 
közvetett magyarázatot adhat arra, miért limitáltak a csaló sejtek lehetőségei a mozgó kolóniában, ugyanis bármelyik ágban jelennek meg a mutánsok, az adott dendrit összeomlása nem lesz hatással a többi ág növekedésére.

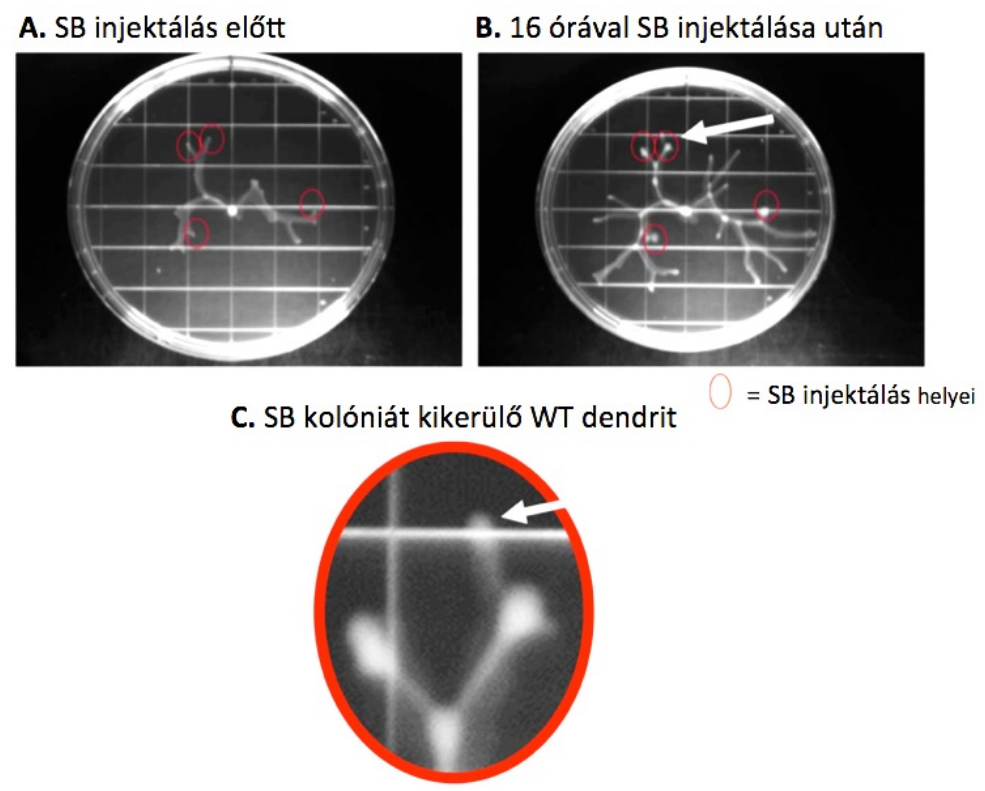

30. ábra: A) Rajzó vad típusú $P$. aeruginosa kolónia növekvő dendritjeinek végére SB mutáns sejteket oltottunk (kb. $10^{8}$ CFU mennyiségben), a vörös körökkel jelölt ágakra. B) A kezelt dendritek növekedése megállt, míg a többi ág normális ütemben növekedett. C) Néhány esetben a rajzó kolónia "kiszabadult" az SB kolóniából (fehér nyíl). Az így növekvő dendrit vagy egyáltalán nem tartalmazott SB sejteket, vagy csak elenyésző mennyiségben $(<1 \%)$. A B és C ábrák 16 órával az SB mutáns leoltása után készültek.

\subsubsection{Populációdinamika in silico modellezése}

A számítógépes szimulációk sok esetben ötleteket nyújthatnak arról, hogyan függ össze a génreguláció a kísérletből származó populációdinamikai eredményekkel. Ezért megpróbáltuk értelmezni a fenti QS deléciós mutánsokkal végzett laboratóriumi kísérleteket az általunk készített hibrid ágens modellel. A szimulációk során WT, SN és SB mutáns ágenseket használtunk, mivel a modellünkben csak 1 db QS rendszer van értelmezve.

Az egyszerűsített modellünk esetében a kevert kolóniák hasonló viselkedési mintázatokat produkálták, mint a Petri csészés kísérleteknél (31. ábra). Vad típusú monokultúra esetében kialakult a stabil, rajzó kolónia. WT+SN kevert kolóniában az SN ágensek aránya beállt egy konstans értékre, mely mellett továbbra is megmaradt a rajzás, viszont kisebb sebességgel, mint a vad típusú kolónia esetében. A harmadik esetben, WT+SB ágensekből álló kolóniánál a rajzás megindulása után a populáció rövid időn belül összeomlott, a növekedés megállt. Az ábrán látható, hogy az utóbbi esetben a WT ágensek 
aránya radikálisan lecsökkent a populációban és a többségben maradt SB ágensek nem voltak képesek fenntartani a rajzást, mivel nem képesek faktort termelni.

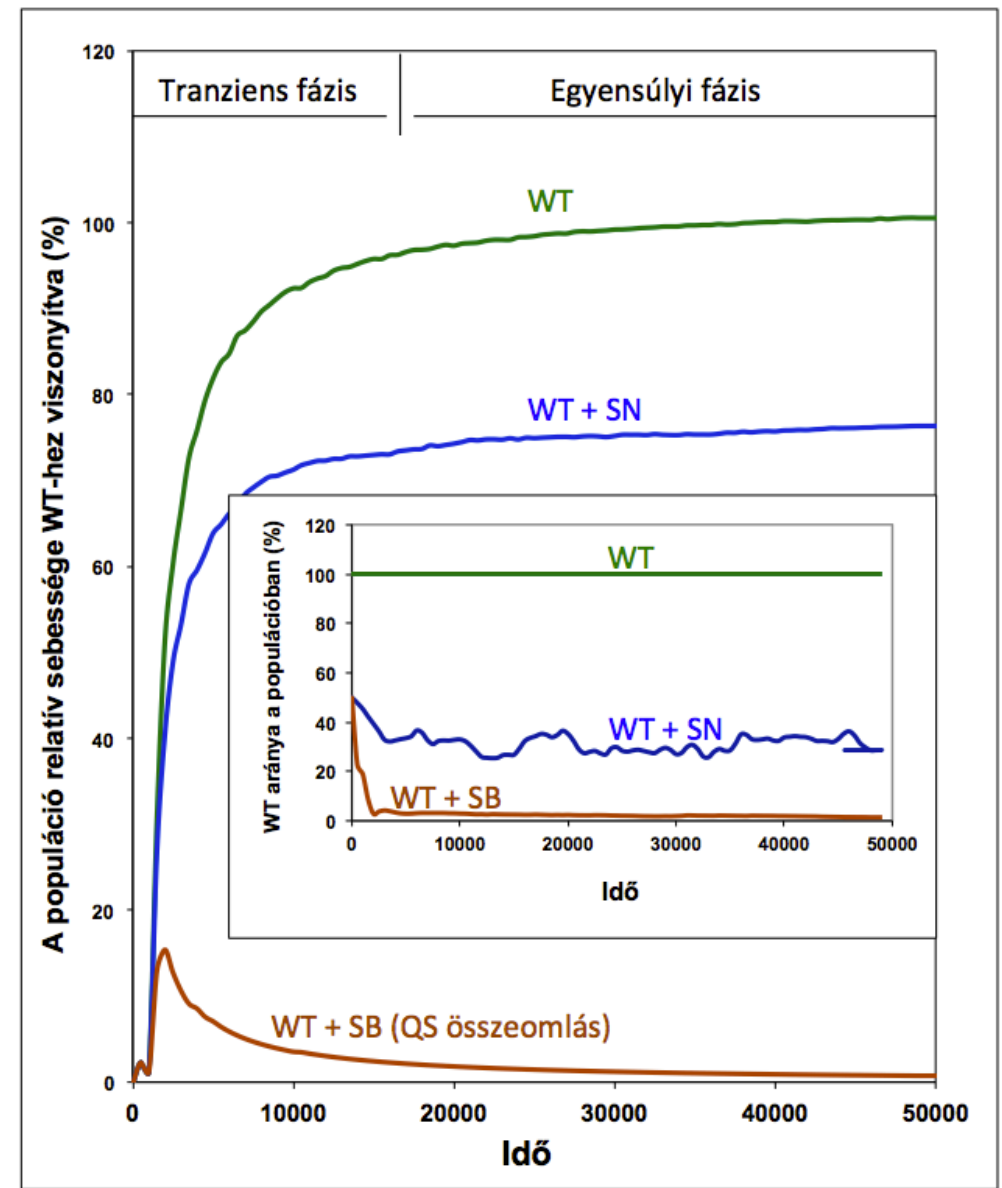

31. ábra: A rajzás in silico vizsgálatához tiszta WT (zöld görbe), ill. kevert populációkat (WT+SN, kék görbe; WT+SB, piros görbe) hoztunk létre. Ez utóbbiak esetében a kiindulási populáció 1:1 arányban tartalmazta a vad típusú és a mutáns törzset. A rajzó populációk növekedése telítési göbével írható le, melyre a kezdeti gyors növekedés után egy tranziens szakasz jellemzö, mely után a populáció egyensúlyba kerül. Ebben a stacioner állapotban a kolónia sebessége és nagysága konstans. Látható, hogy a WT+SN esetben kialakul egy stacioner populáció, mely állapot elérése lassabban következik be, mint a csak WT-böl álló populáció esetében. A WT+SB nem képes közös rajzásra, a populáció ebben az esetben összeomlik.

Az stacioner populációk százalékos összetételét és sebességét az 4. táblázatban foglaltam össze. A relatív szaporodási rátákon ('relative division rate', rDR) - melyet úgy képzünk, hogy a mutáns ágensek osztódási rátáját elosztjuk a vad típusú ágensek osztódási rátájával - jól látszik, hogy az SN mutáns ágensek kismértékü szaporodási előnnyel rendelkeznek a vad típusú ágensekhez képest.

Ennek megfelelően az stacioner populációban a WT-k aránya kisebb, mint ha a WT ágensek egyedül lennének a rendszerben, továbbá a populáció nagysága és sebessége is kisebb. Az SB mutánsok viszont jelentős szaporodási előnnyel rendelkeznek, így hamar 
túlnövik a WT ágenseket. Ennek hatására a populációból eltünnek a kooperáló sejtek, mely által megszünik a rajzáshoz nélkülözhetetlen közjavak termelése, vagyis a populáció összeomlik.

4. táblázat: A különböző kevert populációkkal indított szimulációk legfontosabb jellemzői. A WT+SN szimulációknál az SN sejtek némi előnnyel rendelkeztek a WT-hez képest (rDR), így nagyobb arányban voltak jelen a stacioner kolóniában. Az SN sejtek kooperálnak, viszont nem kommunikálnak, így szaporodási előnyük miatt kisebb méretű és lassabb sebességü populációkat képeztek. A WT+SB szimulációk esetén az SB sejtek egyrészt nem kooperálnak, mástrészről jelentős szaporodási előnnyel rendelkeznek a WT-hez képest. Így rövid időn belül kiszorították a kooperáló partnert a populációból, mely által megszünt a rajzáshoz szükséges faktorok termelése és a kolónia összeomlott.

\begin{tabular}{lllll}
\hline Törzsek (rDR) & $\begin{array}{l}\text { Populáció nagysága } \\
\text { WT-re nézve (\%) }\end{array}$ & $\begin{array}{l}\text { WT ágensek } \\
\text { aránya }(\%)\end{array}$ & Sebesség & $\begin{array}{l}\text { Rajzó ágensek } \\
\text { aránya (\%) }\end{array}$ \\
\hline WT (1.00) & 100 & 100 & 100 & 100 \\
WT+SN (1.03) & 77 & 24.0 & 75 & 99 \\
WT+SB (1.79) & 1 & 0.1 & 0 & 0 \\
\hline
\end{tabular}

Megvizsgáltuk, hogyan változik a fenti kevert populációk esetében a jel és a faktor koncentrációja a rendszerben (32. ábra).
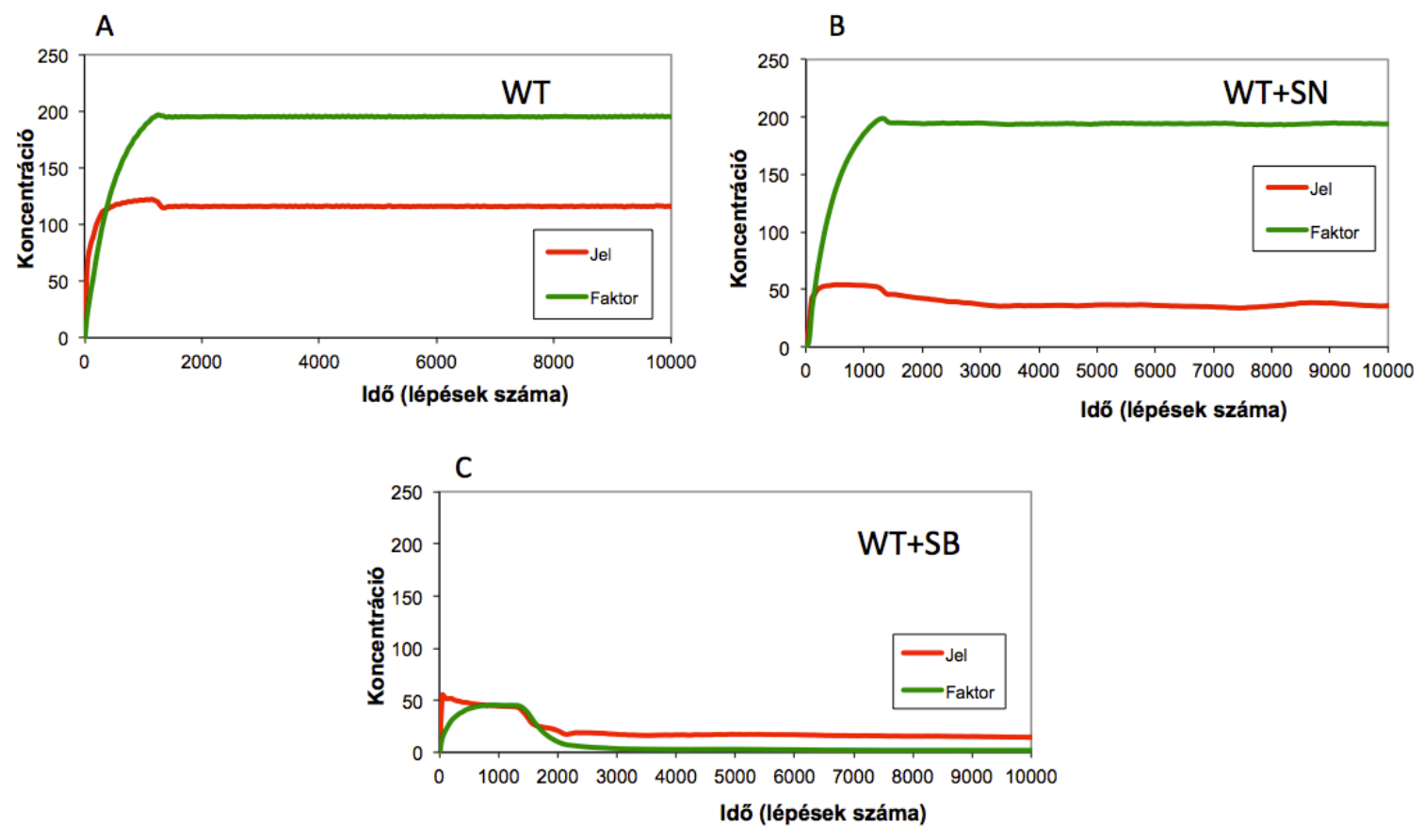

32. ábra: A jel és faktor koncentrációjának változása az idő függvényében. A) WT ágensekkel indított szimuláció jel- és faktorkoncentrációja. B) A WT+SN kevert kultúra adatai alapján látható, hogy a jelkoncentráció jelentősen alacsonyabb a WT-hez képest. C) WT+SB konzorcium jel és faktorkoncentrációjának adatai. Összeomlás után a faktor koncentrációja drasztikusan csökken, és a jelkoncentráció is jelentősen alacsony. Az SB ágensek ugyanis nem képesek faktorokat termelni, és a WT ágensek kiszorításával irreverzibilis módon szüntetik meg a kolónia rajzását. 
Látható, hogy WT+SN kevert populáció esetében a faktorok mennyisége közel azonos, mint a WT populáció esetében. Azonban a jel mennyisége alcsonyabb, vagyis feltételezhető, hogy a WT+SN konzorcium esetében a jelmolekula a limitáló tényező. WT+SB konzorcium esetében a jel koncentráció csökkenése mellett a faktor koncentrációja szinte nullára csökken a rendszerben. Ez egy irreverzibilis változásnak tekinthető, mivel külső jel hozzáadásával már nem állítható vissza az egyensúly.

A rajzó kevert kolóniák összetétele nem függ a kiindulási arányoktól, ugyanis pl. ha az SB csaló mutáns csak elenyésző mennyiségben van jelen a kolóniában, idővel akkor is túl fogja nőni a kooperáló partnert és bekövetkezik az összeomlás (33. ábra).
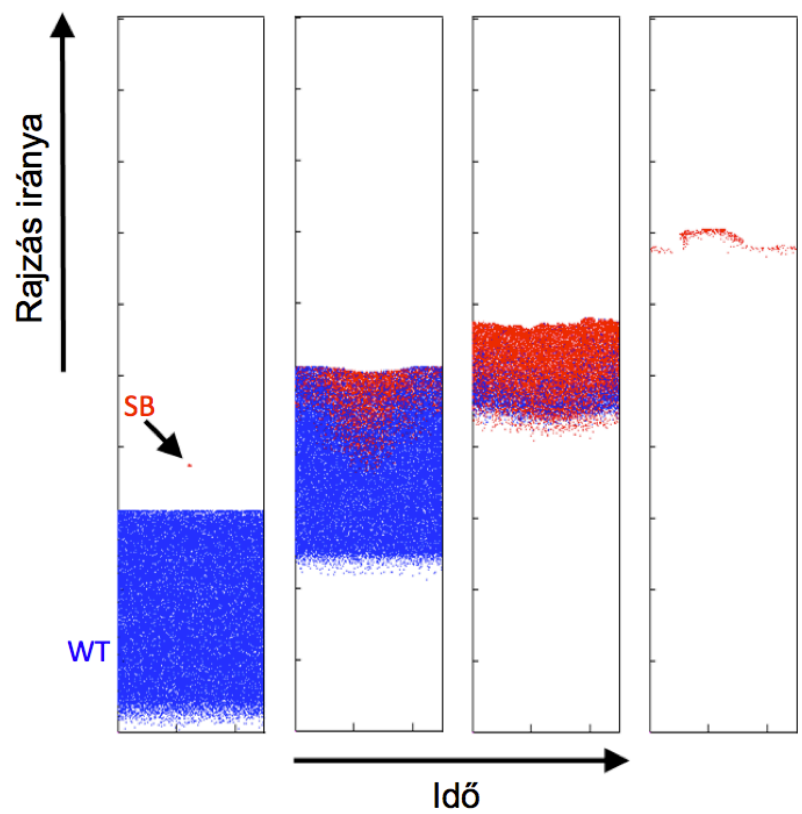

33. ábra: A rajzó WT kolónia (kb. 25.000 ágens) találkozása 10 db SB mutánssal (nyíllal jelölve). A mutáns ágensek rövid időn belül túlnövik a WT sejteket, ami a kolónia összeomlásához vezet. 


\subsection{A kooperáció és kommunikáció in silico vizsgálata két fajból álló közösségekben}

A több fajból álló kolóniák figyelemreméltóan stabil közösségeket képesek kialakítani annak ellenére, hogy a közösséget alkotó fajok gyakorlatilag kompetícióban állnak egymással a közös erőforrásokért. Mindemellett, ezek a konzorciumok rendkívül ellenállóak lehetnek a környezeti változásokkal szemben. A komplementer metabolikus kapcsolat mellett gyakran a QS rendszerek között is létezik átfedés (lásd 1.5. fejezet). Az ágens modellünk segítségével megvizsgáltuk, milyen hatással van a közösség stabilitására, valamint az egyes fajok fitneszére, ha a fajok között a jel, a faktor és táplálék különböző mértékben megosztott.

\subsubsection{A szimulációs rendszer bemutatása}

A kompetíciós szimulációk során két különböző fajból egyenlő számú (1000-1000 db) egyedet helyeztünk a 2D szimulációs tér elejére. A felszínen kétféle tápanyag volt elérhető a két faj számára és alapértelmezésként mindegyik faj csak a saját táplálékán tudott növekedni. Ebben a modellben olyan szimulációs környezetet alkalmaztunk, melyben az adott faj egyedeinek kommunikálniuk és kooperálniuk kellett ahhoz, hogy rajzó állapotba kerüljenek, jelentősen megnövelve így túlélési esélyeiket. Az életképes fajok ebben az esetben egy olyan állandó sebességgel mozgó és közel állandó nagyságú kolóniát alakítottak ki, mely egyenesen haladt elöre a táptalajon a tápanyagban gazdag terület felé. Egy ilyen kolóniát akkor tekintettünk stabilnak, ha a populáció mérete legalább 500 generáción keresztül állandó volt. A nem életképes populációk megrekedtek az alapállapotban és nem tudtak tovább haladni, így a tápanyag felélése után elpusztultak. Ezáltal viszonylag könnyen meg lehetett különböztetni az életképes és a nem életképes kolóniákat.

A szimmetrikus és aszimmetrikus megosztás implementálásához definiáltunk egy koefficienst mindegyik fajra, mely ha 0 volt, akkor nem volt megosztás a fajok között, 1 esetében viszont teljes volt a megosztás (lásd Módszerek 3.4.5. fejezet). A fenti koefficienst bevezettük a szignál (' $a$ '), a faktor (' $b$ ') és a tápanyag megosztásra ('c') is. E három változóval a teljes „kompetíciós teret” lefedhetjük, vagyis pl. $a=b=c=0$ a versengő fajok teljes függetlenséget reprezentálja, míg $a=b=c=1.0$ a teljes megosztást jelenti. Ahhoz, hogy feltérképezzük a kompetíciós teret, különböző szimulációkat futtattunk, melyben a fenti három koefficienst 0 és 1.0 között változtattuk 0.1 lépésközzel ( $c$ esetében 0.2 lépésközzel). Így összesen 11 x 11 x $5=726$ db szimulációt kellett lefuttatni. A szimulációk végeredményeként a versengő populációk különböző pozíciókban voltak egymáshoz képest a 
szimulációs térben. A modellezés során előforduló lehetséges kimenetelek leírásához előzetes szimulációkat futtattunk le. A kapott eredményeket a következőképpen osztályoztuk:

a. Ko-lokalizáció ("co-swarming"): Ebben az esetben a két faj homogén, kevert közösséget alkotott (34. A ábra), mely legalább 500 generáción keresztül fennmarad. A szegregációs koefficines ebben az esetben közel 0 , a relatív fitnesz meghaladhatja az 1-et, vagyis mindkét faj gyorsabban növekedik, mintha egyedül lenne.

b. Nyerés, kompetitív kizárás: csak az egyik faj alkot stabil populációt, míg a másik populáció a fennmaradó táplálék függvényében vagy kihal, vagy egy kisméretü, stagnáló populációt alkot (34. B ábra). A szimulációkat elemezve azt találtuk, hogy kétféle nyerő szituáció létezik: Az egyik esetben bármelyik faj lehet győztes, nagyjából egyenlő eséllyel. Ezt az esetet „sztochasztikus kizárásnak” nevezzük. A másik esetben mindig ugyanaz a faj nyert, melyet „,kompetitív kizárásnak” neveztünk el. A kizárás nagyjából ugyanúgy zajlik le mindkét esetben: a vesztes faj hátramarad a szimulációs térben a győztes fajhoz képest (lásd 34. B ábra), miközben a távolság egyre nőtt az idő elörehaladtával. A vesztes populáció vagy nagyon kis mérettel, de fennmaradt a szimuláció során, vagy fokozatosan eltünt. A nyertes relatív fitnesze 1.0 volt minden esetben.

c. Szegregáció: a két populáció egymástól függetlenül haladt elöre oly módon, hogy az egyik haladt elöl, míg a másik faj lemaradva haladt közvetlenül a másik mögött (34. C1 ábra). Ezeknél az eseteknél is két kimenetelt állapíthattunk meg: az egyik esetben mindig ugyanaz a faj (a jobb kompetítor) került a táplálékhoz közelebb. Ez "kompetítív szegregációnak" neveztük. A másik esetben bármelyik faj lehetett győztes, vagyis kerülhetett előre, melyet "sztochasztikus szegregációnak" hívunk. Mindkét esetben az elöl haladó faj relatív fitnesze 1.0 volt, míg a lemaradó fajé kisebb, mint 1.0, ami extrém esetben 0-hoz konvergált. A szimulációk ismétlése esetén kialakultak ún. „keresztezett”, sakktábla-szerü szegregációk is, melynél az egyik faj volt az első pozícióban a szimulációs tér egy bizonyos felében, míg máshol ugyanez a faj volt lemaradva (34. C2 ábra). Azon a részen, ahol az adott faj vezetett, a relatív fitnesz 1.0-hoz közeli volt, míg a másik esetben a relatív fitnesz 1.0-nál alacsonyabb volt. 


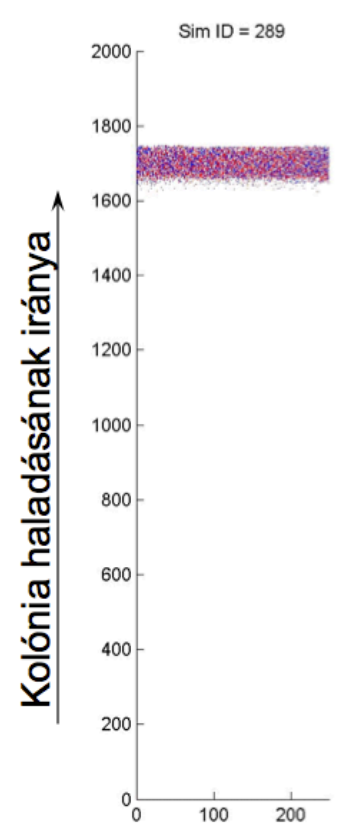

A

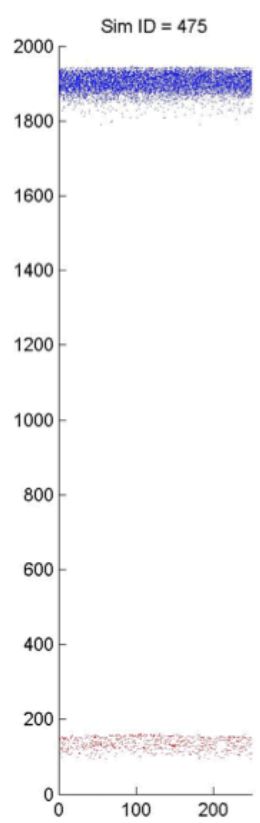

B

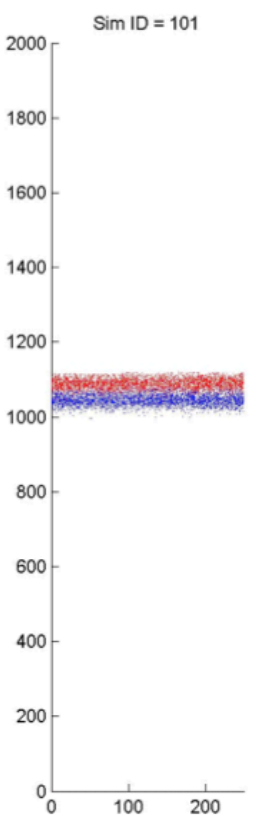

C1

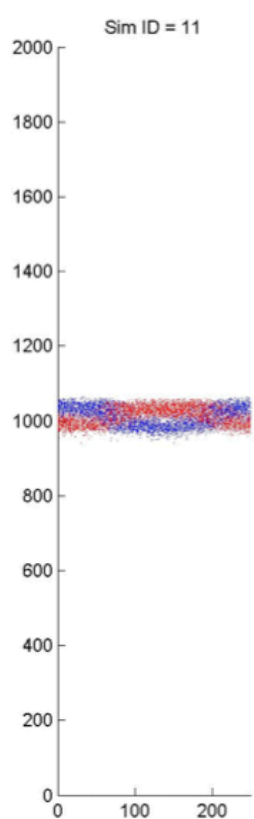

C2

34. ábra: A kompetíció különböző kimenetelei a szimulációs rendszerben. A piros és kék pontok a két fajt reprezentálják a szimulációs térben. A) Stabil, kevert populáció (ko-lokalizáció). Ebben az esetben mindkét faj rajzó állapotban van. B) Nyerés, mely során a nyertes faj egy stabil, rajzó kolóniát alakít ki (kék pontok), míg a másik faj vagy egy stagnáló populációt képez, vagy kihal, a tápanyag mennyiségétől függően. C1) Szegregáló populációk, ahol a piros pontokkal jelzett populáció helyezkedik el a tápanyagban gazdag területekhez közelebb. C2) Mozaik-szerü szegregáció: bizonyos területeken az egyik, míg máshol a másik faj helyezkedik el a közelebb az erőforrásokhoz. Sim ID: a szimuláció azonosítója

\subsubsection{Quorum érzékelés nélküli kompetíció}

Kiindulásként olyan populációkkal végeztünk szimulációkat, melyek nem voltak képesek quorum érzékelésre. Mivel ezekben az esetekben a fajok nem termelnek jelet és faktort - mely által nem képesek állapotot váltani - a növekedés mértékét a tápanyagfelvétel határozza meg.

Az első kísérletekben a szimmetrikus megosztást vizsgáltuk, vagyis mindkét faj elsődlegesen a saját tápanyagát fogyasztotta, valamint a másik faj táplálékából is képes volt fogyasztani. Ez utóbbit a táplálék megosztási koefficiens (c) által határoztuk meg, mely esetben $0 \leq c \leq 1.0$. Ha $c=1.0$, akkor mindkét faj azonos tápanyagforrást fogyaszt, mely esetében sztochasztikus kizárást tapasztaltunk, vagyis az egyik faj 50\%-os valószínűséggel halt ki. Ebben az esetben a kolónia átlagos relatív fitnesze 0.5-re csökkent (az egyik faj relatív fitnesze 1 , a másiké 0 volt). Ha a tápanyag nem volt megosztva $(c=0)$, mindkét faj túlélt sztochasztikus szétválás mellett. Ebben az esetben vagy az egyik, vagy a másik faj került a szimulációs térben előrébb, viszont a hátul maradt faj nem került hátrányba, mivel az a saját 
táplálékát fogyasztotta, ami a másik faj számára indifferens volt. A populáció átlagos fitnesze ebben az esetben 1 körüli volt.

A két szélsőérték között folytonos átmenetet figyeltünk meg, vagyis a sztochasztikus szétválás volt a domináns az alacsonyabb táplálék megosztási koefficiens esetében, ill. sztochasztikus kizárás valósult meg a magasabb c értékek esetén (35. ábra).

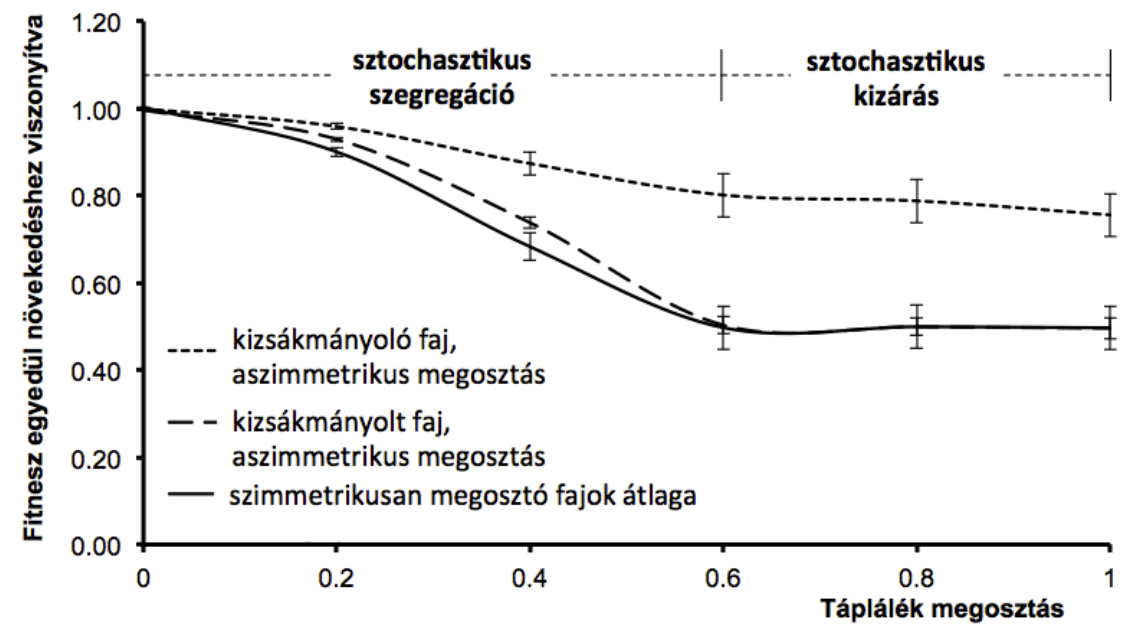

35. ábra: Quorum érzékelés hiányában a rendszerben nincs értelmezve a jel és faktor érzékelés, így a paramétertér egyetlen változója a tápanyag megosztás. A relatív fitneszt az ugyanilyen feltételek mellett, de egyedül növekvő fajra vonatkoztattuk. Alacsony táplálék megosztás esetben a két populáció szegregál és a relatív fitnesz 1 körüli értékre áll be. Magasabb tápanyag megosztás esetében (c $\geq 0.6)$ az egyik faj véletlenszerüen elpusztul. Sztochasztkius szegregáció és kihalás esetén mindkét faj egyforma valószínüséggel lehet nyertes, ill. vesztes. Szimmetrikus megosztás esetében a két faj egyformán képes felhasználni a másik faj táplálékát (alsó folytonos görbe), a táplálék megosztás mértékének növelésével a fajok relatív fitnesze csökkent. Aszimmetrikus megosztás esetében csak az egyik faj képes felhasználni a másik faj táplálékát (felső szaggatott görbe). Megfigyelhető, hogy a kizsákmányolt faj hasonló lefutású relatív fitnesz görbével rendelkezik az aszimmetrikus szimulációk esetében, mint a szimmetrikus táplálékmegosztás görbéje. A feltüntetett értékek 10 párhuzamos szimuláció eredményeinek az átlagát mutatja, a hibasávok a szórást jelölik.

Második menetben megvizsgáltuk az ún. aszimmetrikus megosztást, mely esetében mindkét faj a saját tápanyagát fogyasztotta, de az egyikük (az ún. kizsákmányoló faj, 'exploiter') képes volt a másik faj (kizsákmányolt faj, 'exploited') táplálékát is felhasználni a növekedéshez. Ezeknél a kísérleteknél a kizsákmányoló faj relatív fitnesze magasabb volt. Csak abban az esetben volt egyenlő, ha a két faj független volt egymástól a táplálék szempontjából (ami nem tekinthető kihasználásnak). Minden esetben sztochasztikus volt mind a szegregáció, mind a kizárás.

Fontos megjegyezni, hogy sem a szimmetrikus, sem az aszimmetrikus esetben nem haladta meg a relatív fitnesz értéke az 1.0-t, vagyis a kompetíció minden esetben csökkentette a fajok fitneszét összehasonlítva az ugyanilyen körülmények között, de egyedül létező fajok 
rajzásával. Ez az eredmény nem meglepő, mivel az egyetlen interakció az ágensek között az erőforrásokért (jelen esetben a táplálék) és a térért való versengés, ami exploitív kompetíció megvalósulását eredményezi.

Szintén szem előtt kell tartani, hogy minden kimenetel sztochasztikus volt, vagyis bármelyik faj lehetett vesztes, vagy győztes. Gause kompetitív kizárással kapcsolatos elve alapján, ha két faj különböző növekedési rátával (vagyis fitnesszel) azonos táplálékért verseng, akkor minden esetben a "fittebb" faj fog nyerni [119-120]. A mi szimulációink során mindkét faj fitnesze azonos, ezért abban az esetben tehet szert az egyik elönyre, ha a véletlen folytán több területet tud elfoglalni, mint a másik faj. Mivel az ágensek mozgása véletlenszerü a szimulációs térben, a két versengő faj azonos eséllyel lesz győztes, ill. vesztes. Az általunk vizsgált QS nélküli modellben pontosan ezt tapasztaltuk.

\subsubsection{Szimmetrikus átfedés: "megosztás"}

Szimmetrikus átfedés (szimmetrikus megosztás) esetében - funkcionális QS rendszer jelenléte mellett - mindkét versengő faj képes a másik faj által termelt jel- és faktorérzékelésre, valamint a másik faj által felhasznált táplálék fogyasztásra. A szimulációk eredményei alapján a paraméterteret két zónára lehet felosztani: az egyikben a két faj stabil, kevert kolóniát hoz létre ('ko-lokalizáció', 36. ábra). Ez a jelenség magas faktormegosztás esetén figyelhető meg, jellemzően a jel és faktor hőtérképek bal felső zónájában. Fontos megemlíteni, hogy a működő QS rendszerrel nem rendelkező fajokra futtatott szimulációk (lásd 4.3.2. fejezet) esetében ez a kimenetel nem fordult elő. A szimmetrikus átfedés során a stabil, kevert kolóniákban az egyes fajok relatív fitnesze magasabb volt, mint 1.0 abban az esetben, ha legalább részlegesen különböző táplálékot fogyasztottak (36. ábra). Ez logikus következmény, hiszen a két faj abban az esetben tudja növelni egymás hatékonyságát, ha különböző erőforrásokat használnak fel a közösen használt molekuláris jel és faktor rendszer müködtetéséhez. 
A

\section{Szimmetrikus megosztás}
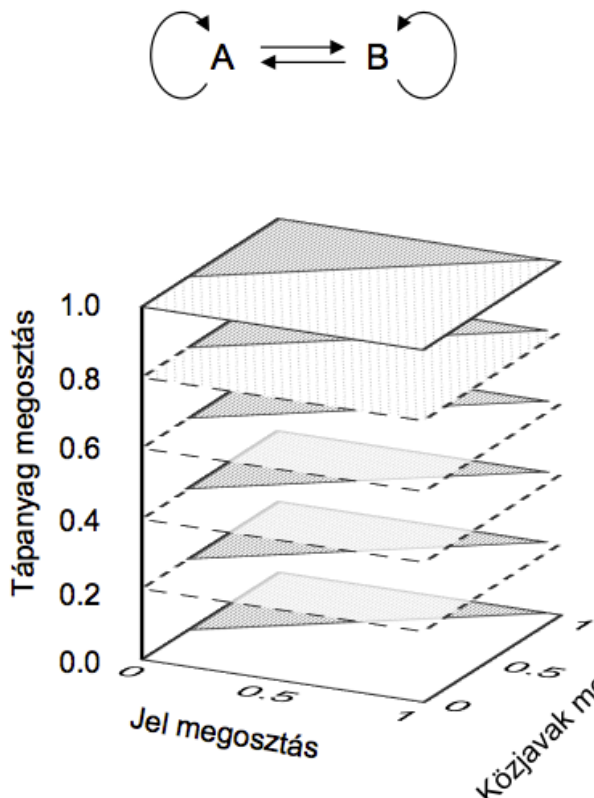

Stabil, kevert közösség

Sztochasztikus kizárás

(bármelyik faj nyerhet)
B

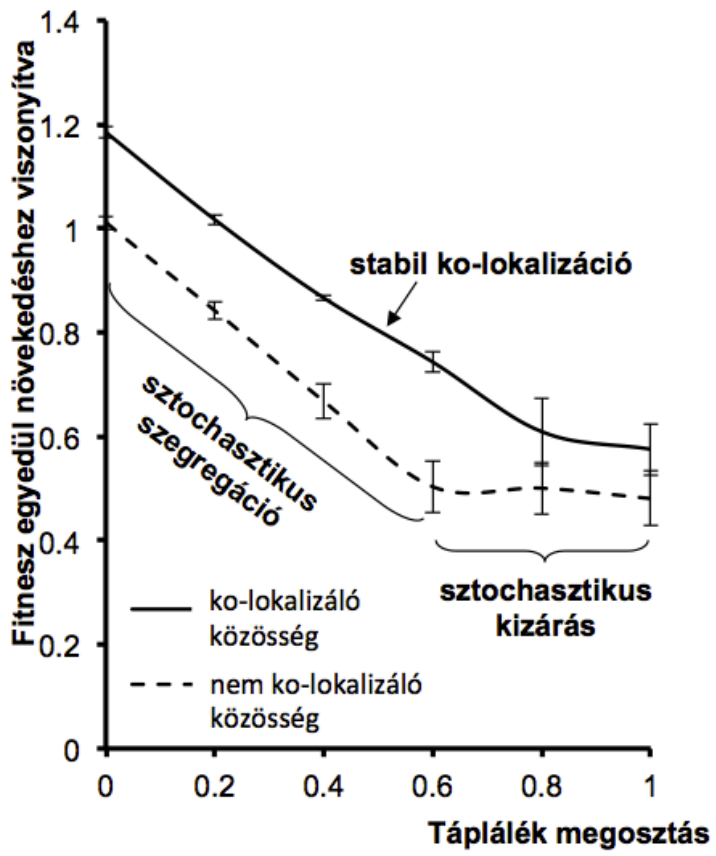

Sztochasztikus szegregáció

(bármelyik faj lehet az erőforrásokhoz közelebb)

36. ábra: A és B fajok kompetíciója, melyek különböző mértékben képesek értelmezni és felhasználni egymás jelét, faktorját és táplálékát. A) Ko-lokalizáló közösségek régiói a paramétertérben. A kevert közösségek magas faktormegosztás esetén alakulnak ki (a sematikus hőtérképek bal felső régiójában). A paramétertér további részében sztochaszitikus kizárás, ill. szegregációt tapasztaltunk a táplálék megosztásátől függően. B) A kevert közösség relatív fitnesze a táplálék megosztás függvényében (felső görbe). Az RF > 1 azt jelöli, hogy a kolónia tagjai gyorsabban növekednek, mintha egyedül lennének a rendszerben. Az alsó görbén a nem ko-lokalizáló kolóniák relatív fitnesze. A feltüntetett értékek 10 párhuzamos szimuláció eredményeinek az átlagát mutatja, a hibasávok a szórást jelölik.

A paramétertér maradék részében a rendszer átmenetet mutatott a sztochasztikus szegregáció (alacsony táplálék megosztás) és a sztochasztikus kizárás (magas táplálék megosztás) között. Ez a viselkedés azonos a QS rendszer nélküli szimulációknál tapasztaltakkal. Megállapíthatjuk tehát, hogy a QS jelek és közjavak szimmetrikus megosztása stabil, kevert populációk kialakulásához vezet, ha a közjavak megosztottak. Ezt a jelenséget a paraméter tér jelentős részében tapasztaltuk magas faktormegosztás esetén, ezért feltételezhetjük, hogy ilyen kevert közösségek viszonylag könnyedén kialakulnak. 


\subsubsection{Aszimmetrikus átfedés: "lehallgatás/kizsákmányolás"}

Az aszimmetrikus kölcsönhatáson alapuló szimulációk során a két faj közül csak az egyik (B faj) képes a másik faj által termelt jel és faktor értelmezésére a saját QS rendszere mellett. Vagyis, B faj gyakorlatilag kizsákmányolja A faj QS rendszerét. Ebben a rendszerben a közösség viselkedése jelentősen eltér az előzőekben bemutatott, szimmetrikus rendszereknél tapasztaltaktól: szegregáció esetén minden esetben a kizsákmányoló faj nyert, ha viszont stabil populációk alakultak ki, akkor minden esetben a kizsákmányoló faj volt az erőforrásokhoz közel (37. ábra). Ezek alapján megállapíthatjuk, hogy a másik faj jelrendszerének a lehallgatása, illetve a közjavak felhasználása előnyös a csaló fél számára.

A

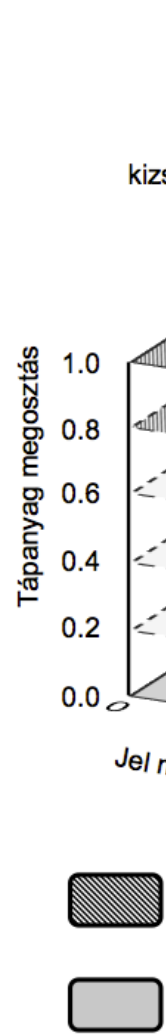

Kizsákmányolás

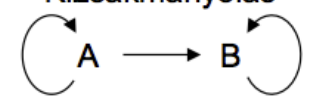

kizsákmányolt kizsákmányoló

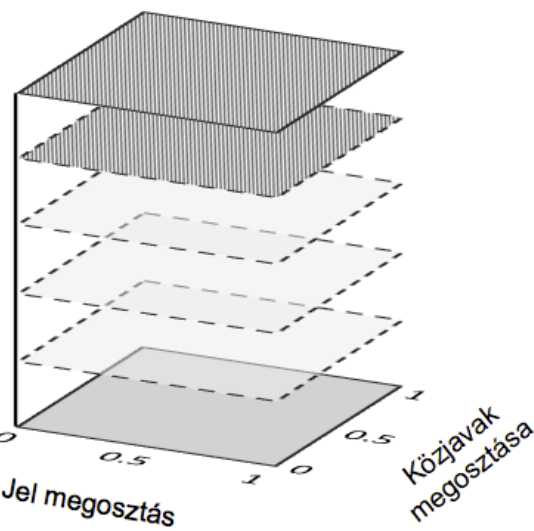

Kompetitív kizárás

(a kizsákmányoló B faj győz)
B

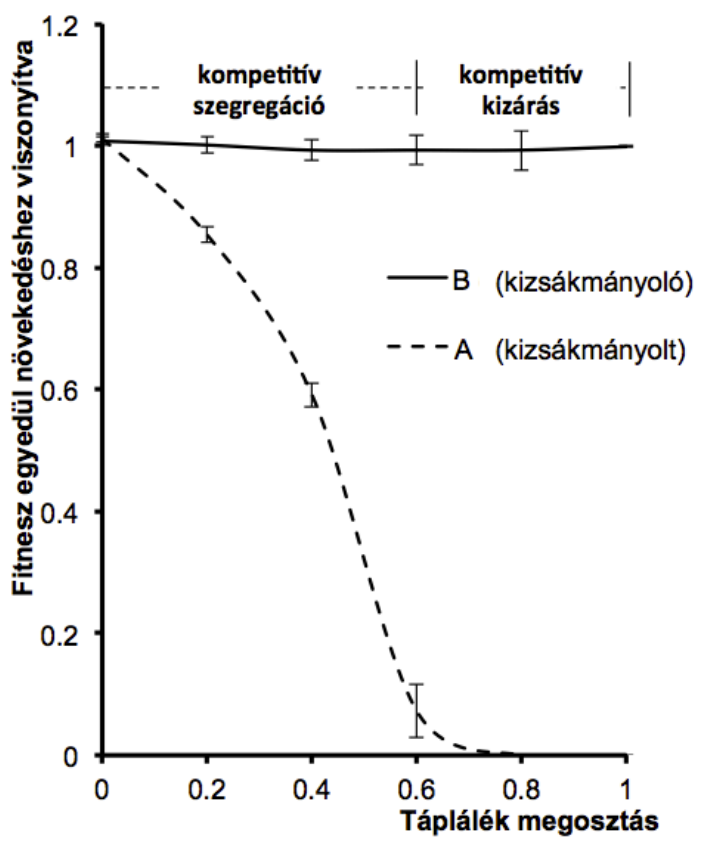

Kompetitív szegregáció

(a kizsákmányoló B faj van az erőforráskhoz közelebb)

37. ábra: A B faj kizsákmányolja A faj QS rendszerét (jel és faktor), valamint a táplálékát. Ez fitnesz előnyhöz juttatja a kizsákmányoló B fajt a teljes paramétertérben. A) A paramétertér különböző régióiban vagy kompetitív kizárást, vagy kompetitív szegregációt tapasztatunk a B faj javára. B) A két faj relatív fitnesze a táplálék megosztás függvényében. A felső görbe $(\mathrm{RF}=1)$ azt mutatja, hogy a $\mathbf{B}$ faj növekedési rátájára nincs hatással a kompetíció. A feltüntetett értékek 10 párhuzamos szimuláció eredményeinek az átlagát mutatja, a hibasávok a szórást jelölik.

Az aszimmetrikus szimulációk során megfigyeltük továbbá, hogy jelentős különbség alakult ki a két faj relatív fitnesze között. Csak abban az esetben figyeltünk meg azonos relatív 
fitneszt, ha a két faj teljesen független volt a jel és faktorérzékelés, valamint a táplálék felhasználás szempontjából (ebben az esetben viszont nem beszélhetünk kizsákmányolásról).

Ennek a rendszernek a viselkedése nagy hasonlóságot mutatott a QS rendszerrel nem rendelkező rendszerekhez a teljes paraméter tér tekintetében (37. ábra). A fö különbség az volt, hogy ebben az esetben a kizsákmányoló faj minden esetben szaporodási előnnyel rendelkezett, még abban az esetben is, ha a táplálék szempontjából nem volt kizsákmányoló. 


\section{5. Összefoglalás}

A mikrobiológia egyik új és izgalmas területe a baktériumok közötti kémiai kommunikáció vizsgálata, melynek során a sejtek diffúzibilis molekulák révén kerülnek egymással kapcsolatba. E jelenségek molekuláris hátterét egyre nagyobb részletességgel ismerjük meg, mely által egyre több kérdésre kapunk választ a mikrobiális közösségek müködésével kapcsolatban. A bakteriális kommunikáció egyik példája a quorum-érzékelés, amely populációsűrüséggel korreláló inger-válasz rendszert jelent. A folyamat által a populáció képes monitorozni a sejtsürüségét, mely ha elér a kritikus szintet, akkor a kolónia génexpressziós mintázata megváltozik. Munkánk középpontjában a $P$. aeruginosa vad típusú és különböző mutáns törzsek quorum érzékelésének in silico és in vitro vizsgálata áll. A vizsgálatok elvégzéséhez megalkottunk egy hibrid ágens modellt, melyben az egyes sejtek önálló döntések meghozására képes ágensekként vannak reprezentálva, míg a a környezetben található kémiai anyagok koncentrációjának változását reakció diffúziós egyenletekkel írtuk le [Netotea, 2009].

A fö különbség a szakirodalmi áttekintésben bemutatott modellek és a mi szimulációs rendszerünk között, hogy míg a korábbi modellekkel a különböző kolónia morfológia mintázatokat quorum-érzékelés nélkül vizsgálták, addig a hibrid ágens modellünk segítségével bepillantást nyerhetünk a QS folyamatok szabályzásába, melyet a termelt anyagok koncentrációjának és diffúziójának explicit ábrázolása tesz lehetővé. Modellünkben az ágens kétfajta anyagot, egy jelanyagot és egy ún. „kooperációs faktort” termelnek. A $P$. aeruginosa esetében előbbi pl. az $N$-acil-homoszerin-lakton molekulának, utóbbi pl. a rajzást lehetővé tevő ramnolipid molekulának vagy a táplálékok feltárását végző elasztáz enzimnek felel meg, melyeket az irodalom „közjavak”-ként szokott aposztrofálni. Ezzel az egyszerüsített modellel hatékonyan szimulálhattuk a rajzás jelenségét, és hasonló eredmények születtek, mint az in vitro kísérletek esetében [Netotea, 2009]. Modellünk egyéni ágensek döntésein alapul, melyek a jel és faktor koncentrációjának függvényében küszöbszerüen váltanak állapotot, azaz kapcsolják be a jel és a kooperációs faktor termelését illetve gyorsítják fel a tápanyagfelvételt és a mozgást. A sejt-modellek (ágensek) random mozgást végeznek és nem rendelkeznek a kemotaxis képességével. Ennek ellenére külső jel érzékelésére képes ágensek kolóniája képes követni növekedésével egy külsőleg hozzáadott jelmolekulákból álló nyomvonalat. A sejt-modellekre az is jellemző, hogy csak a sejten kivüli jel-koncentráció egy szintje fölött képesek rajzó kolóniák létrehozására, ami a modellrendszerben csak bizonyos populációszint felett lehetséges. Más szavakkal kifejezve, a 
modellek tehát rendelkeznek a quorum-érzékelés alaptulajdonságával, vagyis a kolóniák olyan dolgokra képesek, melyeket az egyes sejtek, vagy nagyon kis kolóniák nem képesek végrehajtani.

Megvizsgáltuk, hogy milyen hatással van a populációra, ha különböző QS tevékenységre képtelen ún. csaló mutánsok is jelen vannak a kolóniában. Ilyen mutánsokat in silico úgy hozhatunk létre, hogy az ágens modellekben kikapcsoljuk a jel és/vagy a faktortermelést. Laboratóriumi körülmények között ez a megfelelő gének kiiktatásával történik. A laboratóriumi kísérletek és a szimulációk egyaránt azt mutatták, hogy azok a csaló mutánsok, melyek nem járulnak hozzá a populáció közjavainak - pontosabban a nagy metabolikus ráforditást igénylő kooperációs faktoroknak - termeléséhez, lokális összeomlást okoznak [Venturi, 2010]. Vagyis a quorum-érzékelés egyszerü mechanizmusa elegendő ahhoz, hogy a sejtközösség védett legyen a csaló mutánsok ellen, mivel azok nem képesek elterjedni a teljes kolóniában. A számítógépes szimulációk arra utalnak, hogy a rajzó mozgás és a metabolizmus QS általi szabályozás segítségével a kolónia képes lokalizálni a csaló mutánsokat, meggátolva azok elterjedését. Ez a megfigyelés a káros baktériumok elleni harc új útjaira mutat rá, mivel a deléciós mutánsokkal lehetőség nyílhat a QS kooperáción alapuló bakteriális populációk kontrollálására. Ezen felül megállapítottuk, hogy a kevert populációk jellemző arányai a kezdeti arányoktól függetlenül állnak be a karakterisztikus értékre. A szimulációkból eredményeiből láthattuk, hogy extrém esetben akár néhány darab csaló mutáns ágens is képes egy rajzó kolóniát megállítani és összeomlasztani.

Az utolsó fejezetben arra a kérdésre kerestük a választ, hogy a QS jelek és kooperációs közjavak megosztása hogyan befolyásolja a közös élettérben versengő fajokat [Kerenyi, 2013]. Ehhez olyan szimulációkat futtattunk, melyekben a versengő ágens-populációk különböző mértékben osztották meg a jelmolekuláikat, a közjavaikat és a táplálékot. Azt találtuk, a jelek és közjavak kölcsönös megosztásával stabilisnak tünő (sokszáz generáción kersztül fennáló) kevert populációk alakulhatnak ki a különbözó megosztási arányokat ábrázoló paraméter-tér jelentős részében. Ezt a jelenséget a QS-re nem képes rendszerben egyáltalán nem tapasztaltuk. Az említett vegyes populációkban a két versengő ágenspopuláció teljesen összekeveredett, vagyis ko-lokalizált volt, nem alakult ki foltszerü elkülönülés. A ko-lokalizált populációk ugyanakkor bizonyos esetekben gyorsabban is növekedtek, mint egyedül, azaz a másik faj távollétében. Ezt a jelenséget akkor lehetett megfigyelni, ha a két populáció legalábbis részlegesen, de különböző tápanyagokat fogyasztott. A különböző tápanyagok felhasználását tekinthetjük metabolikus komplementaritásnak, melyet már számos együtt élő mikrobiális konzorcium esetében 
megfigyeltek [121-122]. Modelljeink ennek ellentétét is kimutatták, azaz ha a a két populáció azonos tápanyagot fogyasztott, akkor a szimuláció az egyik populáció kizárásához vezetett. A szimulációk azt sugallják, hogy a közjavak megosztása, valamint a különböző táplálék fogyasztása kulcsfontosságú a ko-lokalizáló populációk kialakításához, míg a jel megosztásának inkább az egyéb fajok odavonzásában lehet szerepe, amint erre fentebb is utaltunk [123]. Egy stabil, kevert közösség természetesen más okokból is előnyhöz juttathatja a résztvevő fajokat. Laboratóriumi kisérletek és számítógépes szimulációk során például megfigyeltük, hogy együtt rajzó fajok kölcsönösen segíthetik egymást, ha csak az egyikük rezisztens egy adott antibiotikumra [123].

Abban az esetben, ha az egyik faj felhasználja a másik faj által termelt jelet és közjavakat, szaporodási előnyre tehet szert a másik fajjal szemben, amelyik nem teheti meg ugyanazt. Ezt aszimmetrikus kizsákmányolásnak nevezzük. A szimulációk szerint a kizsákmányoló fajnak a teljes paramétertérben előnye van, vagyis az idegen faj jelének „lehallgatása”, ill. a annak közjavainak kiaknázása minden körülmények között előnyös a kizsákmányoló faj számára. Ez a szimulációs eredmény azt sugallja, hogy az a sejt, amelynek LuxR receptora többféle jel érzékelésére képes, szaporodási előnnyel rendelkezik, mivel képes válaszolni a vele kompetícióban álló sejtek jeleire is. Mindez magyarázatot adhat a természetben gyakran megfigyelt aspecifikus, több jelet is érzékelni képes LuxR receptorok eredetére. 


\section{Summary}

A novel and exciting field in microbiology is the investigation of chemical communication between bacteria, which is based on diffusible molecules. The molecular background of this phenomenon is getting known in greater and greater details, which provides new insights into the working mechanism of microbial communities. One example of bacterial communication is quorum sensing, which is a stimulus-response system correlated with population density. This mechanism enables the population to monitor its cell density. If the density of the population reaches a critical level, the gene expression pattern of the whole colony is altered.

The main goal of our work was to investigate the quorum sensing of different strains of $\mathrm{P}$. aeruginosa in silico and in vitro. Therefore, an agent based hybrid model was constructed in which bacterial cells were represented as agents, endowed with individual decision-making capacities. In addition, the concentration changes of chemical materials in the environment were described with reaction-diffusion equations [Netotea, 2009].

The main difference between our simulation system and the models described in the literature was that previous models examined colony morphology without qourum sensing. Our model, on the other hand, allows us to study the regulation of quorum sensing processes using an explicit representation of the concentration and diffusion of the materials in the environment. The agents of our model produce two chemicals, signal molecules and the so called "cooperation factor". In the case of $\mathrm{P}$. aeruginosa the signal molecule is an $\mathrm{N}$-acylated homoserine lacton, while the factor corresponds to the rhamnolipid, necessary for swarming or the elastase enzyme, which are often called "public goods". This simplified model allowed us to qualitatively model the swarming phenomenon and the results of the simulations were in good agreement with the in vitro experiments [Netoea, 2009]. Our model is based on the individual decisions of the agents that change their states based on the signal and factor concentration of their environment. By changing their state they switch on signal and factor production as well as their food intake and speed. The agents move randomly on the surface and they are not able to perform chemotaxis, nevertheless, the growth of the colony tracks an artificial path created by an exogenous signal. It is an important property of the cell-models that they can form a swarming colony only when the external concentration of signal is above a given threshold. In the model system this is possible only when the density of the population is above a certain level. In other words the model possesses the fundamentals of quorum 
sensing i.e. the colony can reach goals (e.g. swarming, signal tracking) that are not achievable for single cells or for small colonies.

We examined the effect of cheater mutants, that are not able to participate in quorum sensing activities, on the colony. These mutants can be created in silico by switching off the signal or factor production of the agents. In wet laboratory experiments such mutants are constructed by deleting specific genes. The laboratory experiments and the simulations both showed that cheater mutants, which do not participate in the production of public goods (i.e. the cooperation factors with high metabolic cost) will cause the collapse of the community, but the collapse is local i.e. it does not spread to other parts of a dendritic colony [Venturi, 2010]. Hence, the simple mechanism of quorum sensing is sufficient for the colony to be protected against cheater mutants because they cannot spread in the population. The computational simulation implied that the colony was able to localize cheater mutants and prevent their invasion via the regulation of swarming motility and metabolism. This observation points toward novel strategies in the fight against pathogenic bacteria because QS deletion mutants may combat bacterial populations that use QS cooperation. Furthermore, it was established that the mutant to WT ratios in mixed populations shows characteristic values that are reached regardless of the initial ratios. It was shown by simulations that, in extreme cases, even a few cheater mutant cells were able to collapse a whole swarming community.

In the last chapter we tried to answer the question how sharing QS signals and public goods affect the competition of species living in the same environment [Kerenyi, 2013]. To this purpose, we conducted simulations in which the competing agent populations shared their signals, public goods and nutrients to varying extents. It was found that sharing the signals and public goods lead to the formation of mixed and apparently stable two-species communities that persisted for several hundred generations. This phenomenon occurred in substantial parts of the parameter space. On the other hand, the phenomenon was never observed in systems without QS. In the two-species colonies the competing agent populations were fully mixed i.e. co-localised, without patch formation. In some cases, the co-localised populations were growing faster alone i.e. in the absence of the other species. This phenomenon was observed when the competing populations were using partially different food sources. Using different nutrients can be considered as metabolic complementary that was observed in several natural microbial consortia [131-132]. The opposite case was also observed during the simulations: if the competing populations were using the same nutrient then the simulations ended up with the exclusion one of the competing species. We concluded that sharing the public goods and utilizing different nutrients are essential for the formation of 
co-localised populations while signals could have key roles in recruiting species as mentioned earlier [Netotea, 2009]. A stable, mixed community can offer other benefits for the participants. For instance, our laboratory experiments and simulations demonstrated that coswarming species can help each other if either of the species is resistant to a specific antibiotic [Venturi, 2010].

A species can have reproductive advantage if it can use the signals and public goods of the other species while the other one cannot do the same. This phenomenon is referred to as asymmetric exploitation that is beneficial for the exploiter in the entire parameter space. This simulation result made us conclude that a cell that can detect multiple signals with its LuxR receptor can have reproductive advantage, because it can exploit the signals of competing species. This can explain why aspecific LuxR receptors that can interact with several signal molecules are frequently observed in nature. 


\section{Köszönetnyilvánítás}

Ezúton szeretnék köszönetet mondani elsőként Prof. Pongor Sándornak (MTA SZBK Bioinformatikai Csoport, ICGEB Trieszt, PPKE ITK), aki lehetőséget biztosított arra, hogy a csoportjában végzett munka alapján megszülethessen ez a doktori disszertáció. Továbbá, köszönettel tartozom a munkám során nyújtott szakmai tanácsokért és a dolgozat elkészítése során nyújtott lelkiismeretes segítségéért.

Köszönettel tartozom továbbá Dr. Rákhely Gábornak (SZTE TTIK, Biotechnológiai Tanszék) a doktorandusz éveim alatt nyújtott támogatásáért, valamint a dolgozat írása során nyújtott tanácsokért.

Hálásan köszönöm a segítséget dr. Vittorio Venturinak (ICGEB Trieszt) és a csoportjának, akikkel közreműködve a dolgozat alapjául szolgáló cikkek születtek. Köszönettel tartozom prof. Mircea Munteanunak (University of Udine, Olaszország) a program diffúziós moduljának fejlesztéséért, valamint dr. Kertész-Farkas Attilának (University of Washington, Seattle, Washington, USA) a szimulációk futtatása során nyújtott technikai segítségért.

Szeretném megköszönni továbbá Bihary Dórának (PPKE ITK) a dolgozat készítése során nyújtott szakmai észrevételeit és tanácsait, valamint a sokéves hatékony, közös munkát.

Köszönettel tartozom dr. Galajda Péternek (MTA SZBK) és Prof. Ormos Pálnak (MTA SZBK) a támogatásukért és a türelmükért, melyekről a dolgozatom írása során biztosítottak.

Végül, de nem utolsó sorban hálával tartozom szeretett Családomnak és Barátaimnak kitartó támogatásukért és a bíztatásukért. 


\section{Vonatkozó közlemények}

Netotea, S.; Bertani, I.; Steindler, L.; Kerenyi, A.; Venturi, V.; Pongor, S. A simple model for the early events of quorum sensing in Pseudomonas aeruginosa: modeling bacterial swarming as the movement of an "activation zone". Biology Direct, 2009, 4.

Suárez-Moreno, Z.R.; Kerenyi, A.; Pongor, S.; Venturi, V. Multispecies microbial communities: Part I. Quorum sensing signaling in bacterial and mixed bacterial-fungal communities. Mikologia Lekarska, 2010, 17(2), 4.

Kerenyi, A.; Suarez-Moreno, Z.R.; Venturi, V.; Pongor, S. Multispecies Microbial Communities. Part II: Principles of Molecular Communications. Mikologia Lekarska, 2010, $17(2), 4$.

Venturi, V.; Bertani, I.; Kerenyi, A.; Netotea, S.; Pongor, S. Co-swarming and local collapse: quorum sensing conveys resilience to bacterial communities by localizing cheater mutants in Pseudomonas aeruginosa. PLoS One, 2010, 5(4), e9998.

Venturi, V.; Kerenyi, A.; Reiz, B.; Bihary, D.; Pongor, S. Locality versus globality in bacterial signalling: can local communication stabilize bacterial communities? Biology Direct, 2010, 5 .

Bihary, D.; Kerenyi, A.; Gelencser, Z.; Netotea, S.; Kertesz-Farkas, A.; Venturi, V.; Pongor, S. Simulation of communication and cooperation in multispecies bacterial communities with an agent based model. Scalable Computing: Practice and Experience, 2012, 13(1), 21-28.

Kerenyi, A.; Bihary, D.; Venturi, V.; Pongor, S. Stability of Multispecies Bacterial Communities: Signaling Networks May Stabilize Microbiomes. Plos One, 2013, 8(3). 


\section{Irodalomjegyzék}

[1] Larsen, P.E.; Gibbons, S.M.; Gilbert, J.A. Modeling microbial community structure and functional diversity across time and space. Fems Microbiology Letters, 2012, 332(2), 91-98.

[2] Bladergroen, M.R.; Spaink, H.P. Genes and signal molecules involved in the rhizobiaLeguminoseae symbiosis. Current Opinion in Plant Biology, 1998, 1(4), 353-359.

[3] Perret, X.; Staehelin, C.; Broughton, W.J. Molecular basis of symbiotic promiscuity. Microbiology and Molecular Biology Reviews, 2000, 64(1), 180-+.

[4] Wadhams, G.H.; Armitage, J.P. Making sense of it all: Bacterial chemotaxis. Nature Reviews Molecular Cell Biology, 2004, 5(12), 1024-1037.

[5] Fuqua, W.C.; Winans, S.C.; Greenberg, E.P. Quorum Sensing in Bacteria - the LuxrLuxi Family of Cell Density-Responsive Transcriptional Regulators. Journal of Bacteriology, 1994, 176(2), 269-275.

[6] Pacheco, A.R.; Sperandio, V. Inter-kingdom signaling: chemical language between bacteria and host. Curr Opin Microbiol, 2009, 12(2), 192-8.

[7] Mahowald, M.A.; Rey, F.E.; Seedorf, H.; Turnbaugh, P.J.; Fulton, R.S.; Wollam, A.; Shah, N.; Wang, C.Y.; Magrini, V.; Wilson, R.K.; Cantarel, B.L.; Coutinho, P.M.; Henrissat, B.; Crock, L.W.; Russell, A.; Verberkmoes, N.C.; Hettich, R.L.; Gordon, J.I. Characterizing a model human gut microbiota composed of members of its two dominant bacterial phyla. Proceedings of the National Academy of Sciences of the United States of America, 2009, 106(14), 5859-5864.

[8] Nealson, K.H.; Platt, T.; Hastings, J.W. Cellular control of the synthesis and activity of the bacterial luminescent system. J Bacteriol, 1970, 104(1), 313-22.

[9] Fuqua, C.; Parsek, M.R. Molecular Mechanisms of Quorum Sensing. Modern Microbial Genetics, 2002, 1, 23.

[10] Fuqua, C.; Greenberg, E.P. Listening in on bacteria: Acyl-homoserine lactone signalling. Nature Reviews Molecular Cell Biology, 2002, 3(9), 685-695.

[11] Dubnau, D. Genetic competence in Bacillus subtilis. Microbiol Rev, 1991, 55(3), 395 424.

[12] Eberhard, A.; Burlingame, A.L.; Eberhard, C.; Kenyon, G.L.; Nealson, K.H.; Oppenheimer, N.J. Structural Identification of Autoinducer of PhotobacteriumFischeri Luciferase. Biochemistry, 1981, 20(9), 2444-2449. 
[13] Miller, M.B.; Bassler, B.L. Quorum sensing in bacteria. Annual Review of Microbiology, 2001, 55, 165-199.

[14] Kim, D.; Kwon, Y.K.; Cho, K.H. The biphasic behavior of incoherent feed-forward loops in biomolecular regulatory networks. Bioessays, 2008, 30(11-12), 1204-1211.

[15] Ulrich, R.L.; Hines, H.B.; Parthasarathy, N.; Jeddeloh, J.A. Mutational analysis and biochemical characterization of the Burkholderia thailandensis DW503 quorumsensing network. Journal of Bacteriology, 2004, 186(13), 4350-4360.

[16] O'Grady, E.P.; Viteri, D.F.; Sokol, P.A. A Unique Regulator Contributes to Quorum Sensing and Virulence in Burkholderia cenocepacia. Plos One, 2012, 7(5).

[17] Malott, R.J.; Sokol, P.A. Expression of the bviIR and cepIR quorum-sensing systems of Burkholderia vietnamiensis. Journal of Bacteriology, 2007, 189(8), 3006-3016.

[18] Valade, E.; Thibault, F.M.; Gauthier, Y.P.; Palencia, M.; Popoff, M.Y.; Vidal, D.R. The PmlI-PmlR quorum-sensing system in Burkholderia pseudomallei plays a key role in virulence and modulates production of the MprA protease. Journal of Bacteriology, 2004, 186(8), 2288-2294.

[19] Lopez, D.; Vlamakis, H.; Losick, R.; Kolter, R. Paracrine signaling in a bacterium. Genes \& Development, 2009, 23(14), 1631-1638.

[20] Holden, M.T.G.; Titball, R.W.; Peacock, S.J.; Cerdeno-Tarraga, A.M.; Atkins, T.; Crossman, L.C.; Pitt, T.; Churcher, C.; Mungall, K.; Bentley, S.D.; Sebaihia, M.; Thomson, N.R.; Bason, N.; Beacham, I.R.; Brooks, K.; Brown, K.A.; Brown, N.F.; Challis, G.L.; Cherevach, I.; Chillingworth, T.; Cronin, A.; Crossett, B.; Davis, P.; DeShazer, D.; Feltwell, T.; Fraser, A.; Hance, Z.; Hauser, H.; Holroyd, S.; Jagels, K.; Keith, K.E.; Maddison, M.; Moule, S.; Price, C.; Quail, M.A.; Rabbinowitsch, E.; Rutherford, K.; Sanders, M.; Simmonds, M.; Songsivilai, S.; Stevens, K.; Tumapa, S.; Vesaratchavest, M.; Whitehead, S.; Yeats, C.; Barrell, B.G.; Oyston, P.C.F.; Parkhill, J. Genornic plasticity of the causative agent of melioidosis, Burkholderia pseudomallei. Proceedings of the National Academy of Sciences of the United States of America, 2004, 101(39), 14240-14245.

[21] Kiratisin, P.; Sanmee, S. Roles and Interactions of Burkholderia pseudomallei BpsIR Quorum-Sensing System Determinants. Journal of Bacteriology, 2008, 190(21), 72917297.

[22] Singh, P.K.; Schaefer, A.L.; Parsek, M.R.; Moninger, T.O.; Welsh, M.J.; Greenberg, E.P. Quorum-sensing signals indicate that cystic fibrosis lungs are infected with bacterial biofilms. Nature, 2000, 407(6805), 762-764. 
[23] Zhou, H.; Yao, F.; Roberts, D.P.; Lessie, T.G. AHL-deficient mutants of Burkholderia ambifaria BC-F have decreased antifungal activity. Current Microbiology, 2003, 47(3), 174-179.

[24] Seyedsayamdost, M.R.; Chandler, J.R.; Blodgett, J.A.V.; Lima, P.S.; Duerkop, B.A.; Oinuma, K.I.; Greenberg, E.P.; Clardy, J. Quorum-Sensing-Regulated Bactobolin Production by Burkholderia thailandensis E264. Organic Letters, 2010, 12(4), 716719.

[25] Duerkop, B.A.; Varga, J.; Chandler, J.R.; Peterson, S.B.; Herman, J.P.; Churchill, M.E.A.; Parsek, M.R.; Nierman, W.C.; Greenberg, E.P. Quorum-Sensing Control of Antibiotic Synthesis in Burkholderia thailandensis. Journal of Bacteriology, 2009, 191(12), 3909-3918.

[26] Schmidt, S.; Blom, J.F.; Pernthaler, J.; Berg, G.; Baldwin, A.; Mahenthiralingam, E.; Eberl, L. Production of the antifungal compound pyrrolnitrin is quorum sensingregulated in members of the Burkholderia cepacia complex. Environmental Microbiology, 2009, 11(6), 1422-1437.

[27] Lewenza, S.; Sokol, P.A. Regulation of ornibactin biosynthesis and N-acyl-Lhomoserine lactone production by $\mathrm{CepR}$ in Burkholderia cepacia. Journal of Bacteriology, 2001, 183(7), 2212-2218.

[28] Gelencser, Z.; Choudhary, K.S.; Coutinho, B.G.; Hudaiberdiev, S.; Galbats, B.; Venturi, V.; Pongor, S. Classifying the Topology of AHL-Driven Quorum Sensing Circuits in Proteobacterial Genomes. Sensors, 2012, 12(5), 5432-5444.

[29] Rampioni, G.; Bertani, I.; Pillai, C.R.; Venturi, V.; Zennaro, E.; Leoni, L. Functional Characterization of the Quorum Sensing Regulator RsaL in the Plant-Beneficial Strain Pseudomonas putida WCS358. Applied and Environmental Microbiology, 2012, 78(3), 726-734.

[30] Mattiuzzo, M.; Bertani, I.; Ferluga, S.; Cabrio, L.; Bigirimana, J.; Guarnaccia, C.; Pongor, S.; Maraite, H.; Venturi, V. The plant pathogen Pseudomonas fuscovaginae contains two conserved quorum sensing systems involved in virulence and negatively regulated by RsaL and the novel regulator RsaM. Environmental Microbiology, 2011, 13(1), 145-162.

[31] Venturi, V.; Rampioni, G.; Pongor, S.; Leoni, L. The virtue of temperance: built-in negative regulators of quorum sensing in Pseudomonas. Molecular Microbiology, 2011, 82(5), 1060-1070. 
[32] Hentzer, M.; Wu, H.; Andersen, J.B.; Riedel, K.; Rasmussen, T.B.; Bagge, N.; Kumar, N.; Schembri, M.A.; Song, Z.J.; Kristoffersen, P.; Manefield, M.; Costerton, J.W.; Molin, S.; Eberl, L.; Steinberg, P.; Kjelleberg, S.; Hoiby, N.; Givskov, M. Attenuation of Pseudomonas aeruginosa virulence by quorum sensing inhibitors. Embo Journal, 2003, 22(15), 3803-3815.

[33] Dong, Y.H.; Wang, L.H.; Xu, J.L.; Zhang, H.B.; Zhang, X.F.; Zhang, L.H. Quenching quorum-sensing-dependent bacterial infection by an $\mathrm{N}$-acyl homoserine lactonase. Nature, 2001, 411(6839), 813-817.

[34] Leadbetter, J.R.; Greenberg, E.P. Metabolism of acyl-homoserine lactone quorumsensing signals by Variovorax paradoxus. Journal of Bacteriology, 2000, 182(24), 6921-6926.

[35] Lin, Y.H.; Xu, J.L.; Hu, J.Y.; Wang, L.H.; Ong, S.L.; Leadbetter, J.R.; Zhang, L.H. Acyl-homoserine lactone acylase from Ralstonia strain XJ12B represents a novel and potent class of quorum-quenching enzymes. Molecular Microbiology, 2003, 47(3), 849-860.

[36] Dong, Y.H.; Xu, J.L.; Li, X.Z.; Zhang, L.H. AiiA, an enzyme that inactivates the acylhomoserine lactone quorum-sensing signal and attenuates the virulence of Erwinia carotovora. Proceedings of the National Academy of Sciences of the United States of America, 2000, 97(7), 3526-3531.

[37] Ozer, E.A.; Pezzulo, A.; Shih, D.M.; Chun, C.; Furlong, C.; Lusis, A.J.; Greenberg, E.P.; Zabner, J. Human and murine paraoxonase 1 are host modulators of Pseudomonas aeruginosa quorum-sensing. Fems Microbiology Letters, 2005, 253(1), 29-37.

[38] Yang, F.; Wang, L.H.; Wang, J.; Dong, Y.H.; Hu, J.Y.; Zhang, L.H. Quorum quenching enzyme activity is widely conserved in the sera of mammalian species. Febs Letters, 2005, 579(17), 3713-3717.

[39] Stoltz, D.A.; Ozer, E.A.; Ng, C.J.; Yu, J.M.; Reddy, S.T.; Lusis, A.J.; Bourquard, N.; Parsek, M.R.; Zabner, J.; Shih, D.M. Paraoxonase-2 deficiency enhances Pseudomonas aeruginosa quorum sensing in murine tracheal epithelia. American Journal of Physiology-Lung Cellular and Molecular Physiology, 2007, 292(4), L852L860.

[40] Teiber, J.F.; Horke, S.; Haines, D.C.; Chowdhary, P.K.; Xiao, J.H.; Kramer, G.L.; Haley, R.W.; Draganov, D.I. Dominant role of paraoxonases in inactivation of the Pseudomonas aeruginosa quorum-sensing signal N-(3-oxododecanoyl)-L-homoserine lactone. Infection and Immunity, 2008, 76(6), 2512-2519. 
[41] Delalande, L.; Faure, D.; Raffoux, A.; Uroz, S.; D'Angelo-Picard, C.; Elasri, M.; Carlier, A.; Berruyer, R.; Petit, A.; Williams, P.; Dessaux, Y. N-hexanoyl-Lhomoserine lactone, a mediator of bacterial quorum-sensing regulation, exhibits plantdependent stability and may be inactivated by germinating Lotus corniculatus seedlings. Fems Microbiology Ecology, 2005, 52(1), 13-20.

[42] Skerker, J.M.; Berg, H.C. Direct observation of extension and retraction of type IV pili. Proceedings of the National Academy of Sciences of the United States of America, 2001, 98(12), 6901-6904.

[43] Van Delden, C.; Iglewski, B.H. Cell-to-cell signaling and Pseudomonas aeruginosa infections. Emerging Infectious Diseases, 1998, 4(4), 551-560.

[44] Williams, P.; Camara, M.; Hardman, A.; Swift, S.; Milton, D.; Hope, V.J.; Winzer, K.; Middleton, B.; Pritchard, D.I.; Bycroft, B.W. Quorum sensing and the populationdependent control of virulence. Philosophical Transactions of the Royal Society BBiological Sciences, 2000, 355(1397), 667-680.

[45] Smith, R.S.; Iglewski, B.H. P-aeruginosa quorum-sensing systems and virulence. Current Opinion in Microbiology, 2003, 6(1), 56-60.

[46] Pesci, E.C.; Milbank, J.B.J.; Pearson, J.P.; McKnight, S.; Kende, A.S.; Greenberg, E.P.; Iglewski, B.H. Quinolone signaling in the cell-to-cell communication system of Pseudomonas aeruginosa. Proceedings of the National Academy of Sciences of the United States of America, 1999, 96(20), 11229-11234.

[47] Calfee, M.W.; Coleman, J.P.; Pesci, E.C. Interference with Pseudomonas quinolone signal synthesis inhibits virulence factor expression by Pseudomonas aeruginosa. Proceedings of the National Academy of Sciences of the United States of America, 2001, 98(20), 11633-11637.

[48] Lepine, F.; Deziel, E.; Milot, S.; Rahme, L.G. A stable isotope dilution assay for the quantification of the Pseudomonas quinolone signal in Pseudomonas aeruginosa cultures. Biochimica Et Biophysica Acta-General Subjects, 2003, 1622(1), 36-41.

[49] Gallagher, L.A.; McKnight, S.L.; Kuznetsova, M.S.; Pesci, E.C.; Manoil, C. Functions required for extracellular quinolone signaling by Pseudomonas aeruginosa. Journal of Bacteriology, 2002, 184(23), 6472-6480.

[50] D'argenio, D.A.; Calfee, M.W.; Rainey, P.B.; Pesci, E.C. Autolysis and autoaggregation in Pseudomonas aeruginosa colony morphology mutants. Journal of Bacteriology, 2002, 184(23), 6481-6489. 
[51] Hentzer, M.; Givskov, M. Pharmacological inhibition of quorum sensing for the treatment of chronic bacterial infections. Journal of Clinical Investigation, 2003, 112(9), 1300-1307.

[52] McKnight, S.L.; Iglewski, B.H.; Pesci, E.C. The Pseudomonas quinolone signal regulates rhl quorum sensing in Pseudomonas aeruginosa. Journal of Bacteriology, 2000, 182(10), 2702-2708.

[53] Holden, M.T.G.; Chhabra, S.R.; de Nys, R.; Stead, P.; Bainton, N.J.; Hill, P.J.; Manefield, M.; Kumar, N.; Labatte, M.; England, D.; Rice, S.; Givskov, M.; Salmond, G.P.C.; Stewart, G.S.A.B.; Bycroft, B.W.; Kjelleberg, S.A.; Williams, P. Quorumsensing cross talk: isolation and chemical characterization of cyclic dipeptides from Pseudomonas aeruginosa and other Gram-negative bacteria. Molecular Microbiology, 1999, 33(6), 1254-1266.

[54] Ruby, E.G. Lessons from a cooperative, bacterial-animal association: The Vibrio fischeri Euprymna scolopes light organ symbiosis. Annual Review of Microbiology, 1996, 50, 591-624.

[55] Daniels, R.; Vanderleyden, J.; Michiels, J. Quorum sensing and swarming migration in bacteria. Fems Microbiology Reviews, 2004, 28(3), 261-289.

[56] Whitehead, N.A.; Barnard, A.M.L.; Slater, H.; Simpson, N.J.L.; Salmond, G.P.C. Quorum-sensing in gram-negative bacteria. Fems Microbiology Reviews, 2001, 25(4), 365-404.

[57] Redfield, R.J. Is quorum sensing a side effect of diffusion sensing? Trends in Microbiology, 2002, 10(8), 365-370.

[58] Shapiro, J.A. Thinking about bacterial populations as multicellular organisms. Annu Rev Microbiol, 1998, 52, 81-104.

[59] Henrichsen, J. Bacterial surface translocation: a survey and a classification. Bacteriol Rev, 1972, 36(4), 478-503.

[60] Harshey, R.M. Bees Arent the Only Ones - Swarming in Gram-Negative Bacteria. Molecular Microbiology, 1994, 13(3), 389-394.

[61] Sharma, M.; Anand, S.K. Swarming: A coordinated bacterial activity. Current Science, 2002, 83(6), 707-715.

[62] Fraser, G.M.; Hughes, C. Swarming motility. Current Opinion in Microbiology, 1999, 2(6), 630-635. 
[63] Senesi, S.; Celandroni, F.; Salvetti, S.; Beecher, D.J.; Wong, A.C.L.; Ghelardi, E. Swarming motility in Bacillus cereus and characterization of a fliY mutant impaired in swarm cell differentiation. Microbiology-Sgm, 2002, 148, 1785-1794.

[64] Soto, M.J.; Fernandez-Pascual, M.; Sanjuan, J.; Olivares, J. A fadD mutant of Sinorhizobium meliloti shows multicellular swarming migration and is impaired in nodulation efficiency on alfalfa roots. Molecular Microbiology, 2002, 43(2), 371-382.

[65] Ghelardi, E.; Celandroni, F.; Salvetti, S.; Beecher, D.J.; Gominet, M.; Lereclus, D.; Wong, A.C.L.; Senesi, S. Requirement of flhA for swarming differentiation, flagellin export, and secretion of virulence-associated proteins in Bacillus thuringiensis. Journal of Bacteriology, 2002, 184(23), 6424-6433.

[66] Ron, E.Z.; Rosenberg, E. Natural roles of biosurfactants. Environmental Microbiology, 2001, 3(4), 229-236.

[67] Sauer, K.; Camper, A.K.; Ehrlich, G.D.; Costerton, J.W.; Davies, D.G. Pseudomonas aeruginosa displays multiple phenotypes during development as a biofilm. Journal of Bacteriology, 2002, 184(4), 1140-1154.

[68] Sauer, K.; Camper, A.K. Characterization of phenotypic changes in Pseudomonas putida in response to surface-associated growth. Journal of Bacteriology, 2001, 183(22), 6579-6589.

[69] Winzer, K.; Hardie, K.R.; Burgess, N.; Doherty, N.; Kirke, D.; Holden, M.T.G.; Linforth, R.; Cornell, K.A.; Taylor, A.J.; Hill, P.J.; Williams, P. LuxS: its role in central metabolism and the in vitro synthesis of 4-hydroxy-5-methyl-3(2H)-furanone. Microbiology-Sgm, 2002, 148, 909-922.

[70] Waters, C.M.; Bassler, B.L. The Vibrio harveyi quorum-sensing system uses shared regulatory components to discriminate between multiple autoinducers. Genes \& Development, 2006, 20(19), 2754-2767.

[71] Thoendel, M.; Horswill, A.R. Biosynthesis of Peptide Signals in Gram-Positive Bacteria. Advances in Applied Microbiology, Vol 71, 2010, 71, 91-112.

[72] Kleerebezem, M.; Quadri, L.E.N.; Kuipers, O.P.; deVos, W.M. Quorum sensing by peptide pheromones and two-component signal-transduction systems in Gram-positive bacteria. Molecular Microbiology, 1997, 24(5), 895-904.

[73] Camilli, A.; Bassler, B.L. Bacterial small-molecule signaling pathways. Science, 2006, 311(5764), 1113-1116. 
[74] Waters, C.M.; Bassler, B.L. Quorum sensing: Cell-to-cell communication in bacteria. Annual Review of Cell and Developmental Biology, 2005, 21, 319-346.

[75] Ji, G.Y.; Beavis, R.C.; Novick, R.P. Cell density control of staphylococcal virulence mediated by an octapeptide pheromone. Proceedings of the National Academy of Sciences of the United States of America, 1995, 92(26), 12055-12059.

[76] Ansaldi, M.; Marolt, D.; Stebe, T.; Mandic-Mulec, I.; Dubnau, D. Specific activation of the Bacillus quorum-sensing systems by isoprenylated pheromone variants. Molecular Microbiology, 2002, 44(6), 1561-1573.

[77] Pestova, E.V.; Havarstein, L.S.; Morrison, D.A. Regulation of competence for genetic transformation in Streptococcus pneumoniae by an auto-induced peptide pheromone and a two-component regulatory system. Molecular Microbiology, 1996, 21(4), 853862.

[78] Barber, C.E.; Tang, J.L.; Feng, J.X.; Pan, M.Q.; Wilson, T.J.G.; Slater, H.; Dow, J.M.; Williams, P.; Daniels, M.J. A novel regulatory system required for pathogenicity of Xanthomonas campestris is mediated by a small diffusible signal molecule. Molecular Microbiology, 1997, 24(3), 555-566.

[79] Dow, J.M.; Crossman, L.; Findlay, K.; He, Y.Q.; Feng, J.X.; Tang, J.L. Biofilm dispersal in Xanthomonas campestris is controlled by cell-cell signaling and is required for full virulence to plants. Proceedings of the National Academy of Sciences of the United States of America, 2003, 100(19), 10995-11000.

[80] Guo, Y.P.; Zhang, Y.P.; Li, J.L.; Wang, N.A. Diffusible Signal Factor-Mediated Quorum Sensing Plays a Central Role in Coordinating Gene Expression of Xanthomonas citri subsp citri. Molecular Plant-Microbe Interactions, 2012, 25(2), 165-179.

[81] Ryan, R.P.; McCarthy, Y.; Watt, S.A.; Niehaus, K.; Dow, J.M. Intraspecies Signaling Involving the Diffusible Signal Factor BDSF (cis-2-Dodecenoic Acid) Influences Virulence in Burkholderia cenocepacia. Journal of Bacteriology, 2009, 191(15), 50135019.

[82] Deng, Y.Y.; Schmid, N.; Wang, C.; Wang, J.H.; Pessi, G.; Wu, D.H.; Lee, J.; Aguilar, C.; Ahrens, C.H.; Chang, C.Q.; Song, H.W.; Eberl, L.; Zhang, L.H. Cis-2-dodecenoic acid receptor RpfR links quorum-sensing signal perception with regulation of virulence through cyclic dimeric guanosine monophosphate turnover. Proceedings of the National Academy of Sciences of the United States of America, 2012, 109(38), 15479-15484. 
[83] De Sordi, L.; Muhlschlegel, F.A. Quorum sensing and fungal-bacterial interactions in Candida albicans: a communicative network regulating microbial coexistence and virulence. FEMS Yeast Res, 2009, 9(7), 990-9.

[84] Peleg, A.Y.; Hogan, D.A.; Mylonakis, E. Medically important bacterial-fungal interactions. Nature Reviews Microbiology, 2010, 8(5), 340-349.

[85] Wargo, M.J.; Hogan, D.A. Fungal-bacterial interactions: a mixed bag of mingling microbes. Current Opinion in Microbiology, 2006, 9(4), 359-364.

[86] Hornby, J.M.; Jensen, E.C.; Lisec, A.D.; Tasto, J.J.; Jahnke, B.; Shoemaker, R.; Dussault, P.; Nickerson, K.W. Quorum sensing in the dimorphic fungus Candida albicans is mediated by farnesol. Applied and Environmental Microbiology, 2001, 67(7), 2982-2992.

[87] Chen, H.; Fujita, M.; Feng, Q.H.; Clardy, J.; Fink, G.R. Tyrosol is a quorum-sensing molecule in Candida albicans. Proceedings of the National Academy of Sciences of the United States of America, 2004, 101(14), 5048-5052.

[88] Gibson, J.; Sood, A.; Hogan, D.A. Pseudomonas aeruginosa-Candida albicans Interactions: Localization and Fungal Toxicity of a Phenazine Derivative. Applied and Environmental Microbiology, 2009, 75(2), 504-513.

[89] Hogan, D.A.; Kolter, R. Pseudomonas-Candida interactions: An ecological role for virulence factors. Science, 2002, 296(5576), 2229-2232.

[90] Suárez-Moreno, Z.R.; Kerényi, Á.; Pongor, S.; Venturi, V. Multispecies microbial communities: Part I. Quorum sensing signaling in bacterial and mixed bacterial-fungal communities. Mikologia Lekarska, 2010, 17(2), 4.

[91] McAlester, G.; O'Gara, F.; Morrissey, J.P. Signal-mediated interactions between Pseudomonas aeruginosa and Candida albicans. Journal of Medical Microbiology, 2008, 57(5), 563-569.

[92] Kerényi, Á.; Suárez-Moreno, Z.R.; Venturi, V.; Pongor, S. Multispecies Microbial Communities. Part II: Principles of Molecular Communications. Mikologia Lekarska, 2010, 17(2), 4 .

[93] Duan K.; Sibley C.D.; C.J., D.; M.G., S. Chemical interactions between organisms in microbial communities. Contrib Microbiol 2009, 16, 17.

[94] Shank, E.A.; Kolter, R. New developments in microbial interspecies signaling. Current Opinion in Microbiology, 2009, 12(2), 205-214. 
[95] Gavini, F.; Mergaert, J.; Beji, A.; Mielcarek, C.; Izard, D.; Kersters, K.; Deley, J. Transfer of Enterobacter-Agglomerans (Beijerinck 1888) Ewing and Fife 1972 to Pantoea Gen-Nov as Pantoea-Agglomerans Comb Nov and Description of PantoeaDispersa Sp-Nov. International Journal of Systematic Bacteriology, 1989, 39(3), 337345.

[96] Rojas, A.M.; de los Rios, J.E.G.; Saux, M.F.L.; Jimenez, P.; Reche, P.; Bonneau, S.; Sutra, L.; Mathieu-Daude, F.; McClelland, M. Erwinia toletana sp nov., associated with Pseudomonas savastanoi-induced tree knots. International Journal of Systematic and Evolutionary Microbiology, 2004, 54, 2217-2222.

[97] Hosni, T.; Moretti, C.; Devescovi, G.; Suarez-Moreno, Z.R.; Fatmi, M.B.; Guarnaccia, C.; Pongor, S.; Onofri, A.; Buonaurio, R.; Venturi, V. Sharing of quorum-sensing signals and role of interspecies communities in a bacterial plant disease. Isme Journal, 2011, 5(12), 1857-1870.

[98] Fuqua, C.; Parsek, M.R.; Greenberg, E.P. Regulation of gene expression by cell-to-cell communication: Acyl-homoserine lactone quorum sensing. Annual Review of Genetics, 2001, 35, 439-468.

[99] Kawasaki, K.; Mochizuki, A.; Matsushita, M.; Umeda, T.; Shigesada, N. Modeling spatio-temporal patterns generated by Bacillus subtilis. Journal of Theoretical Biology, 1997, 188(2), 177-185.

[100] Bonabeau, E. Agent-based modeling: Methods and techniques for simulating human systems. Proceedings of the National Academy of Sciences of the United States of America, 2002, 99, 7280-7287.

[101] Reynolds, C.W. Flocks, Herds, and Schools: A Distributed Behavioral Model. Computer Graphics, 1987, 21(4), 10.

[102] Benjacob, E.; Schochet, O.; Tenenbaum, A.; Cohen, I.; Czirok, A.; Vicsek, T. Generic Modeling of Cooperative Growth-Patterns in Bacterial Colonies. Nature, 1994, $368(6466), 46-49$.

[103] Benjacob, E.; Cohen, I.; Shochet, O.; Aranson, I.; Levine, H.; Tsimring, L. Complex Bacterial Patterns. Nature, 1995, 373(6515), 566-567.

[104] Golding, I.; Cohen, I.; Benjacob, E. Spatio-selection in expanding bacterial colonies. Physica A., 1999.

[105] Neumann, J. The general and logical theory of automata. Cerebral Mechanisms in Behavior, 1951, 31. 
[106] Gerlee, P.; Anderson, A.R.A. Stability analysis of a hybrid cellular automaton model of cell colony growth. Physical Review E, 2007, 75(5).

[107] Netotea, S.; Bertani, I.; Steindler, L.; Kerenyi, A.; Venturi, V.; Pongor, S. A simple model for the early events of quorum sensing in Pseudomonas aeruginosa: modeling bacterial swarming as the movement of an "activation zone". Biology Direct, 2009, 4.

[108] Luo, X.L.; Wu, H.C.; Tsao, C.Y.; Cheng, Y.; Betz, J.; Payne, G.F.; Rubloff, G.W.; Bentley, W.E. Biofabrication of stratified biofilm mimics for observation and control of bacterial signaling. Biomaterials, 2012, 33(20), 5136-5143.

[109] Zhang, Y.; Ho, Y.P.; Chiu, Y.L.; Chan, H.F.; Chlebina, B.; Schuhmann, T.; You, L.C.; Leong, K.W. A programmable microenvironment for cellular studies via microfluidics-generated double emulsions. Biomaterials, 2013, 34(19), 4564-4572.

[110] Boedicker, J.Q.; Vincent, M.E.; Ismagilov, R.F. Microfluidic Confinement of Single Cells of Bacteria in Small Volumes Initiates High-Density Behavior of Quorum Sensing and Growth and Reveals Its Variability. Angewandte Chemie-International Edition, 2009, 48(32), 5908-5911.

[111] Kumar, R.S.; Ayyadurai, N.; Pandiaraja, P.; Reddy, A.V.; Venkateswarlu, Y.; Prakash, O.; Sakthivel, N. Characterization of antifungal metabolite produced by a new strain Pseudomonas aeruginosa PUPa3 that exhibits broad-spectrum antifungal activity and biofertilizing traits. Journal of Applied Microbiology, 2005, 98(1), 145-154.

[112] Steindler, L.; Bertani, I.; De Sordi, L.; Schwager, S.; Eberl, L.; Venturi, V. LasI/R and RhlI/R Quorum Sensing in a Strain of Pseudomonas aeruginosa Beneficial to Plants. Applied and Environmental Microbiology, 2009, 75(15), 5131-5140.

[113] Atkinson, K.E. An introduction to numerical analysis, 2nd edition. John Wiley \& Sons, Inc., 1989.

[114] Bihary, D.; Kerenyi, A.; Gelencser, Z.; Netotea, S.; Kertesz-Farkas, A.; Venturi, V.; Pongor, S. Simulation of communication and cooperation in multispecies bacterial communities with an agent based model. Scalable Computing: Practice and Experience, 2012, 13(1), 21-28.

[115] Mitri, S.; Xavier, J.B.; Foster, K.R. Social evolution in multispecies biofilms. Proceedings of the National Academy of Sciences of the United States of America, 2011, 108, 10839-10846.

[116] Nadell, C.D.; Foster, K.R.; Xavier, J.B. Emergence of Spatial Structure in Cell Groups and the Evolution of Cooperation. Plos Computational Biology, 2010, 6(3). 
[117] Diggle, S.P.; Griffin, A.S.; Campbell, G.S.; West, S.A. Cooperation and conflict in quorum-sensing bacterial populations. Nature, 2007, 450(7168), 411-U7.

[118] Sandoz, K.M.; Mitzimberg, S.M.; Schuster, M. Social cheating in Pseudomonas aeruginosa quorum sensing. Proceedings of the National Academy of Sciences of the United States of America, 2007, 104(40), 15876-15881.

[119] Gause, G.F. The struggle for existence. Baltimore, 1934.

[120] Hardin, G. The competitive exclusion principle. Science 1960, 131, 5.

[121] McCutcheon, J.P.; McDonald, B.R.; Moran, N.A. Convergent evolution of metabolic roles in bacterial co-symbionts of insects. Proceedings of the National Academy of Sciences of the United States of America, 2009, 106(36), 15394-15399.

[122] Wu, D.; Daugherty, S.C.; Van Aken, S.E.; Pai, G.H.; Watkins, K.L.; Khouri, H.; Tallon, L.J.; Zaborsky, J.M.; Dunbar, H.E.; Tran, P.L.; Moran, N.A.; Eisen, J.A. Metabolic complementarity and genomics of the dual bacterial symbiosis of sharpshooters. Plos Biology, 2006, 4(6), 1079-1092.

[123] Venturi, V.; Bertani, I.; Kerenyi, A.; Netotea, S.; Pongor, S. Co-swarming and local collapse: quorum sensing conveys resilience to bacterial communities by localizing cheater mutants in Pseudomonas aeruginosa. PLoS One, 2010, 5(4), e9998. 


\section{Függelék}

1. táblázat. A rajzó kolóniák vizsgálatához használ "M8" agar médium pontos kémiai összetétele. A médiumot két komponens, az agar oldat és a sóoldat 1:1 arányú elegyéből állítjuk elő. A táblázatban 1 liter médium előállításához szükséges mennyiségek vannak felsorolva, ami kb. 50 db Petri csésze elkészítéséhez elegendő.

\begin{tabular}{lr|lr}
\hline Agar oldat (500 $\mathbf{~ m l})$ & & Sóoldat $\mathbf{( 5 0 0 ~} \mathbf{~ m l})$ \\
\hline BACTO Agar por & $5 \mathrm{~g}$ & $\mathrm{Na}_{2} \mathrm{HPO}_{4}-12 \mathrm{H}_{2} \mathrm{O}$ & $15.12 \mathrm{~g}$ \\
Víz & $500 \mathrm{ml}$ & $\mathrm{KH}_{2} \mathrm{PO}_{4}$ & $3 \mathrm{~g}$ \\
& & $\mathrm{NaCl}$ & $0.5 \mathrm{~g}$ \\
& & Glutaminsav & $0.5 \mathrm{~g}$ \\
& & Víz & $480 \mathrm{ml}$ \\
& $\mathrm{CaCl}_{2}(1 \mathrm{M}$ törzsoldat $)$ & $100 \mathrm{ml}$ \\
& $\mathrm{Glükóz}$ & $2 \mathrm{~g}$ \\
& $\mathrm{MgSO}_{4}(1 \mathrm{M}$ törzsoldat $)$ & $2 \mathrm{ml}$ \\
\hline
\end{tabular}


2. táblázat: A szimulációk során használt legfontosabb paraméterek és képletek összefoglalása

\begin{tabular}{|c|c|c|c|}
\hline Szimbólum & Leírás & Érték(ek) & Egyenlet \\
\hline $\mathbf{n}_{\max }$ & Szimulációs lépések max. száma & 40000 & - \\
\hline $\mathbf{c}_{\max }$ & Sejtek max. száma cellánként & 10 & - \\
\hline $\mathbf{L}_{\mathbf{x}}$ & $\begin{array}{l}\text { Szimulációs tér mérete } \\
\text { (x dimenzió) }\end{array}$ & 250 & - \\
\hline $\mathbf{L}_{\mathbf{y}}$ & $\begin{array}{l}\text { Szimulációs tér mérete } \\
\text { (y dimenzió) }\end{array}$ & 2000 & - \\
\hline $\mathbf{L}_{\mathbf{x}}$ & $\begin{array}{l}\text { Cellák száma a szimulációs téren } \\
\text { (x dimenzió) }\end{array}$ & 50 & - \\
\hline $\mathbf{L}_{\mathrm{y}}$ & $\begin{array}{l}\text { Cellák száma a szimulációs téren } \\
\text { (y dimenzió) }\end{array}$ & 200 & - \\
\hline $\mathbf{C}_{\mathbf{N}}$ & $\begin{array}{l}\text { Kezdeti tápanyagkoncentráció } \\
\text { cellánként }\end{array}$ & 500 & - \\
\hline $\mathbf{N}_{\text {start }}$ & Kezdeti sejtszám $\left(\mathrm{S}_{1}, \mathrm{~S}_{2}\right)$ & 1000,1000 & - \\
\hline $\mathbf{v}$ & $\begin{array}{l}\text { Ágensek sebssége } \\
\text { (alap/aktiv/ rajzó állapot) }\end{array}$ & $1.5 / 1.5 / 5.0$ & - \\
\hline $\mathbf{E}_{\mathrm{N}}$ & Táplálékkal felvett energia & $0.3 / 0.3 / 0.5$ & - \\
\hline $\mathbf{E}_{\mathbf{S}}$ & Jeltermelésre fordított energia & $0.005 / 0.025 / 0.025$ & - \\
\hline $\mathbf{E}_{\mathbf{F}}$ & Faktortermelésre fordított energia & $0.0 / 0.15 / 0.15$ & - \\
\hline $\mathbf{E}_{\mathbf{M}}$ & $\begin{array}{l}\text { Vegetatív funkciókra fordított } \\
\text { energia }\end{array}$ & 0.1 & - \\
\hline $\mathbf{E}_{\mathrm{t}}$ & $\begin{array}{l}\text { Teljes raktározott energia } t+1 \\
\text { időpontban }\end{array}$ & - & $\mathrm{E}_{(\mathrm{t}+1)}=\mathrm{E}_{\mathrm{t}}+\mathrm{E}_{\mathrm{N}}+\mathrm{E}_{\mathrm{S}}+\mathrm{E}_{\mathrm{F}}+\mathrm{E}_{\mathrm{M}}$ \\
\hline $\mathbf{P}_{\mathbf{S}}$ & Termelt jel mennyisége & $0.1 / 0.5 / 0.5$ & - \\
\hline $\mathbf{P}_{\mathbf{F}}$ & Termelt faktor mennyisége & $0.0 / 0.1 / 0.1$ & - \\
\hline $\mathbf{T}_{\mathrm{S}}$ & Jel küszöbkoncentrációja & 10 & \\
\hline $\mathbf{T}_{\mathbf{F}}$ & Faktor küszöbkoncentrációja & 10 & \\
\hline$\delta$ & Osztódási küszöbenergia & 12 & \\
\hline $\mathbf{k}$ & "Border Advancement" állandója & $0.5 / 0.1$ & $\mathrm{k}=0.05 / \mathrm{P}_{\mathrm{F}}$ \\
\hline BAT & $\begin{array}{l}\text { "Border Advancement" } \\
\text { küszöbértéke }\end{array}$ & 1 & \\
\hline BC & $\begin{array}{l}\text { "Border Advancement" } \\
\text { számlálójának képlete }\end{array}$ & & $\mathrm{BC}_{(\mathrm{t}+1)}=\mathrm{BC}_{\mathrm{t}}+\left(\mathrm{kF}_{1, \mathrm{t}}\right)+\left(\mathrm{kF}_{2, \mathrm{t}}\right)$ \\
\hline $\mathbf{D}_{\mathrm{N}}$ & Tápanyag diffúziós állandója & 0.03 & - \\
\hline $\mathbf{D}_{\mathrm{S}}$ & Jel diffúziós állandója & 0.02 & - \\
\hline
\end{tabular}




\begin{tabular}{llll}
\hline Szimbólum & Leírás & Érték(ek) & Egyenlet \\
\hline $\mathbf{D}_{\mathbf{F}}$ & Faktor diffúziós állandója & 0.05 & - \\
$\mathbf{R}_{\mathbf{S}}$ & Jel bomlási állandója & 0.001 & - \\
$\mathbf{R}_{\mathbf{F}}$ & Faktor bomlási állandója & 0.0001 & - \\
$\boldsymbol{F}$ & Fitnesz képlete & - & $F=\frac{1}{\Delta t} \log _{2} \frac{N_{\text {end }}}{N_{\text {start }}}$ \\
$\boldsymbol{F}_{\boldsymbol{r e l}}$ & Relatív fitnesz képlete & - & $F_{\text {rel }}=\log _{2}\left(\frac{N_{\text {end }}}{N_{\text {start }}}\right) / \log _{2}\left(\frac{N_{\text {end,wt }}}{N_{\text {start,wt }}}\right)$ \\
$\boldsymbol{S G}$ & Szegregációs index képlete & - & $S G=\frac{\sum_{i} \max \left(n_{i}\right)}{N_{\text {pop }}}$ \\
$\boldsymbol{S G N}$ & Normalizált szegregációs index & - & $S G N=\left(S G-\frac{1}{N_{\text {species }}}\right) /\left(1-\frac{1}{N_{\text {species }}}\right)$ \\
\hline
\end{tabular}

